\title{
IMPROVED BIOREFINERY FOR THE PRODUCTION OF ETHANOL, Chemicals, ANimal FeEd AND Biomaterials fROM SUgar CANE
}

\author{
DE-FG36-04G014236
}

\author{
FinAL REPORT \\ To \\ U.S. Department of Energy
}

April1, 2004 through June 30, 2008

\author{
Submitted by \\ Professor Donal Day \\ Audubon Sugar Institute \\ LSU Agricultural Center \\ 3845 Highway 75 \\ St. Gabriel, LA 70776 \\ Contact: \\ Donal F.Day, PhD. \\ Telephone: 225-642-0135 \\ Fax: 225-642-8790 \\ E-mail: dday@agctr.Isu.edu \\ LSU Agricultural Center \\ Audubon Sugar Institute \\ FOR THE PERIOD APRIL 1, 2004 - JUNE 30, 2008 \\ Feed and Biomaterial from Sugar Cane
}

Final Report for Grant \# DE-FG36-04G014236

Improved Biorefinery for the Production of Ethanol, Chemicals, Animal 


\section{TABLE OF CONTENTS}

Executive Summary

Strategic Tasks (this includes modifications to original tasks made for the 2006-2008 extension)

Task 1. AFEX Pretreatment, Enzymatic Hydrolysis, and Solid/liquid Separation........2

Sub Task 1. AFEX pretreatment of bagasse and CLM........................2 Summary

Sub-Task 2. Conversion of AFEX treated materials to succinic acid Summary....................................................4

Sub-Task 3. Produce large quantities of AFEX-treated bagasse and CLM To proceed with the tasks in this grant and DE-FG36-05GO85007, kilogram quantities of AFEX-treated bagasse and CLM were needed. Hence, large quantities of bagasse and CLM material had to be collected and treated)

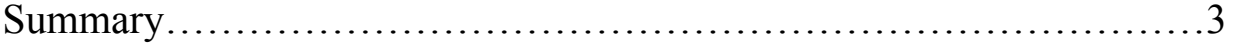

Scale-up..................................................... 18

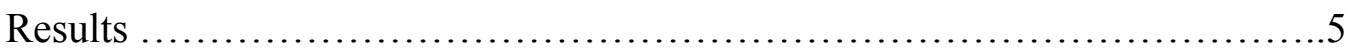

Materials and Methods (task 1) ..................................... 21

Task 2. Alkaline Treatment, Solid/liquid Separation and Lignin Recovery.........25

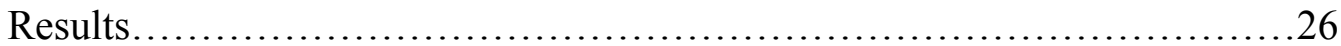

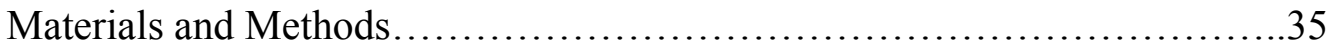

Task 3. Cellulose hydrolysis........................................... 37

Results..............................................................

Materials and Methods..............................................48

Task 4. Produce ethanol through a fermentation that uses bagasse and molasses as feedstock .................................................................. 51

Results....................................................... 51 
Task 5: Thermochemical conversion of bagasse.............................54

Sub-Task 5.1. Design and execute an experimental matrix of subcritical aqueous alkali-catalyzed conversion tests with sugarcane solids. Characterize liquid, gas and solid products of the conversions.......................54

Subtask 5.2 Experimentally determine the yields of Syngas per unit mass of

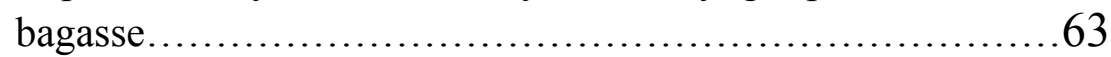

Materials and Methods...............................................6

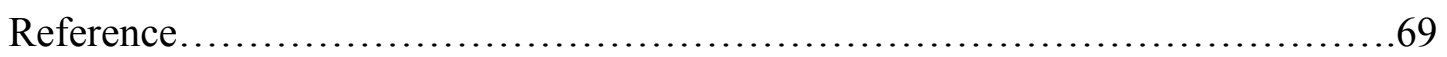

Project summary....................................................... 71

Publications and Technology Transfer.................................... 72 


\section{EXECUTIVE SUMMARY}

The Audubon Sugar Institute (ASI) of Louisiana State University's Agricultural Center (LSU AgCenter) and MBI International (MBI) sought to develop technologies that will lead to the development of a sugar-cane biorefinery, capable of supplying fuel ethanol from bagasse. Technology development focused on the conversion of bagasse, cane-leaf matter (CLM) and molasses into high value-added products that included ethanol, specialty chemicals, biomaterials and animal feed; i.e. a sugar cane-based biorefinery. The key to lignocellulosic biomass utilization is an economically feasible method (pretreatment) for separating the cellulose and the hemicellulose from the physical protection provided by lignin. An effective pretreatment disrupts physical barriers, cellulose crystallinity, and the association of lignin and hemicellulose with cellulose so that hydrolytic enzymes can access the biomass macrostructure (Teymouri et al. 2004, Laureano-Perez, 2005). We chose to focus on alkaline pretreatment methods for, and in particular, the Ammonia Fiber Expansion (AFEX) process owned by MBI. During the first two years of this program a laboratory process was established for the pretreatment of bagasse and CLM using the AFEX process. There was significant improvement of both rate and yield of glucose and xylose upon enzymatic hydrolysis of AFEX-treated bagasse and CLM compared with untreated material. Because of reactor size limitation, several other alkaline pretreatment methods were also co-investigated. They included, dilute ammonia, lime and hydroxyhypochlorite treatments. Scale-up focused on using a dilute ammonia process as a substitute for AFEX, allowing development at a larger scale. The pretreatment of bagasse by an ammonia process, followed by saccharification and fermentation produced ethanol from bagasse. Simultaneous saccharification and fermentation (SSF) allowed two operations in the same vessel. The addition of sugarcane molasses to the hydrolysate/fermentation process yielded improvements beyond what was expected solely from the addition of sugar. In order to expand the economic potential for building a biorefinery, the conversion of enzyme hydrolysates of AFEX-treated bagasse to succinic acid was also investigated. This program established a solid basis for pre-treatment of bagasse in a manner that is feasible for producing ethanol at raw sugar mills. 


\section{Project objectives and tasks}

The rationale for this project was to develop and evaluate scalable, integrated technologies utilizing bagasse, molasses and CLM for the production of ethanol, chemicals, biomaterials and animal feeds that can be used in a sugar mill based biorefinery. All efforts in this project were directed towards investigating those processes that could be integrated into a raw sugar mill.

\section{Objectives}

1) Develop a scalable AFEX biomass pretreatment process for bagasse (Tasks 1 and 2).

2) Develop and demonstrate processes that utilize components from sugar cane; bagasse, CLM and molasses for ethanol production (Tasks 4, 5, 6). This required scaling up AN AFEX reactor from 1-gallon capacity to 5-gallon capacity both to obtain processing data for future modeling and economic analysis of pilot plant scale AFEX pretreatment and to produce larger amounts of AFEX-treated material for fermentations. Continue investigation of those processes thought to offer opportunities to contribute to biorefinery economics (Tasks 3, 5). Scale up the fermentation experiments to collect data for process analysis and to produce representative stillage. This includes an investigation of gasification of bagasse for the production of Syngas in sub- and supercritical conditions. This objective was added later to the original proposal.

Task 1. AFEX Pretreatment, Enzymatic Hydrolysis, and Solid/liquid Separation The primary objective of this task was to develop, optimize and demonstrate an AFEX pretreatment process to produce fermentable sugars and other products from bagasse and CLM.

\section{Sub Task 1. AFEX pretreatment of bagasse and CLM.}

\section{Summary}

The primary objective of this study was to evaluate the efficiency of the AFEX process in the pretreatment of bagasse pith and cane leaf matter (CLM). Enzyme hydrolysis of AFEX-treated bagasse pith and CLM generates streams of fermentable sugars containing both C5 (xylose and arabinose) and C6 sugars (glucose). Maximal utilization of all the biomass polymeric sugar is essential to make the economics of biomass processing feasible. Alkaline treated biomass, unlike acid treated material, has a significant amount of hemicellulose that needs to be hydrolyzed to monomeric sugars. AFEX-treated bagasse, pith and CLM were hydrolyzed with combinations of cellulase and xylanase to maximize both glucose and xylose yields. The generated C5 and C6 sugar streams are useful in the production of fuels and chemicals such as ethanol and succinic acid. 
The AFEX process conditions, which include reaction time, reaction temperature, ammonia loading, and moisture content of the biomass, were varied to determine those conditions that provide the highest glucose and xylose yield. The efficiency of the AFEX process was evaluated using enzyme hydrolysis. The most effective AFEX treatment conditions for bagasse pith and CLM were found to be $100^{\circ} \mathrm{C}$, a biomass moisture content of $40 \%$, a reaction time of 30 minutes, and an ammonia loading of $2 \mathrm{~g}$ ammonia per gram dry biomass. Combinations of cellulase and xylanase produced higher glucose and xylose yields from AFEX-treated material compared to hydrolysis with only cellulase. A process was developed for the separation of hemicellulose and cellulose from AFEX-treated CLM and bagasse pith using selective hydrolysis of hemicellulose by using cellulase-free xylanases for selective hydrolysis of the hemicellulose. For AFEXtreated CLM, about $52 \%$ of the xylan was converted to xylose while about $96 \%$ of the cellulose was left in the biomass. For AFEX-treated bagasse pith, about $56 \%$ of the xylan, but only $5 \%$ of the cellulose, was hydrolyzed.

The enzyme hydrolysate of AFEX-treated bagasse can be converted to ethanol via Separate Hydrolysis and Fermentation (SHF) process. Zymomonas mobilis pZB5, an organism capable of converting both glucose and xylose to ethanol, was used for this fermentation. The fermentations were run at two different solids loadings, $4 \%$ and $8 \%$. These fermentations were successful and all the generated sugars were converted. However, the ethanol concentration was low, $15 \mathrm{~g} / 1$ at an $8 \%$ solids loading. The concentration of the individuals products strongly influences product recovery cost and is critical to the success of recovery and the downstream processing systems. The efficient recovery of ethanol requires an ethanol concentration of at least $4 \%(\mathrm{w} / \mathrm{v})$, which in turn requires a starting concentration of fermenting sugar higher than $8 \%(\mathrm{w} / \mathrm{v})$ (Grohmann, 1993). Due to the extreme sensitivity of current cellulolytic enzymes to end-product inhibition, high concentrations of sugar (glucose) in the enzyme hydrolysis process could not be achieved. This shortcoming of the SHF process can be addressed by a process called Simultaneous Saccharification and Fermentation (SSF). In SSF, a cellulase enzyme and microorganisms are added to the substrate at the same time in a fermentation vessel. The microorganism will metabolize the sugars as soon as they are released. The SSF process typically results in a higher concentration of ethanol as compared to the SHF process. Furthermore, performing SSF in a fed batch manner (solid biomass is incrementally fed to the fermentation vessel) may yield even higher concentrations of ethanol.

In an effort to increase ethanol concentrations, fed batch simultaneous saccharification and fermentation (SSF) was investigated for ethanol production from materials. In these fermentations, the solids loading were incrementally increased by batch feeding the biomass to the fermentor. Two microorganisms, Zymomonas mobilis and Saccharomyces cerevisiae were tested. Up to $25 \%$ solids loading and a concentration of ethanol of up to $28 \mathrm{~g} / 1$ was achieved in these fermentations. The fermentation results from Saccharomyces cerevisiae were promising, but the fermentations with Z. mobilis gave pooryields.

Sub-Task 2. Conversion of AFEX treated materials to succinic acid 


\section{Summary}

Succinic acid is a four-carbon dicarboxylic acid used to manufacture polymers and resins for lacquers, dyes and perfumes, industrial solvents, and newly developed products such as de-icing chemicals. Succinic acid is produced predominantly from petroleum-based feedstocks. It can be produced via bacterial fermentation using renewable biomassderived sugars. MBI has identified and developed a bacterium, Actinobacillus succinogenes, capable of utilizing both hexose and pentose sugars simultaneously for the production of succinic acid. This organism produces $75-80 \mathrm{~g} / 1$ of succinic acid in 48 hours with greater than $90 \%$ yields. Fermentability of the enzyme hydrolysate from AFEX-treated CLM was assessed for succinic acid production. Using SHF processes, with two different solid loadings for succinic acid fermentation with Actinobacillus succinogenes FZ45 generated sugars (C5 and C6) were converted to succinic acid.

MBI's existing ASPEN Plus-based process model for production of succinic acid from pure sugars was modified to evaluate the technical and economic performance of succinic acid production from AFEX-treated biomass. The existing ASPEN Plus-based process model for production of ethanol from AFEX-treated switchgrass was also modified to evaluate the technical and economic performance of ethanol production from AFEX-treated bagasse. Both models showed that the capital and manufacturing costs would be decreased if the cost associated with hydrolysis was decreased. Lowering the purchase price of cellulases directly lowers the manufacturing cost. Improving cellulase activity in the presence of increased solids loading would provide a lower AFEX cost, a higher succinic acid and ethanol titer, and lower downstream processing costs.

\section{Sub-task 3. Produce large quantities of AFEX-treated bagasse and CLM}

In order to scale the process to something larger than laboratory experiments, sufficient quantity of pretreated feedstocks are required. This was addressed two ways; by scaling up the AFEX reactor and by using an AFEX stimulant (not part of this project). 


\section{Task 1. Results}

Optimization of AFEX treatment conditions for bagasse, pith and bulk production of AFEX-treated fractionated bagasse and CLM solids

Table 1. Composition of Bagasse, Bagasse Pith, and CLM (based on dry weight)

\begin{tabular}{|l|c|c|c|c|c|c|}
\hline & $\begin{array}{c}\text { Glucan } \\
\%\end{array}$ & $\begin{array}{c}\text { Xylan } \\
\%\end{array}$ & $\begin{array}{c}\text { Galactan } \\
\%\end{array}$ & $\begin{array}{c}\text { Arabinan } \\
\%\end{array}$ & $\begin{array}{c}\text { Ash } \\
\%\end{array}$ & $\begin{array}{c}\text { Extractive } \\
\%\end{array}$ \\
\hline CLM & 27.09 & 20.01 & 1.44 & 2.34 & 5.7 & 3.2 \\
\hline Bagasse & 34.6 & 18.49 & 00.45 & 0.95 & 6.5 & 2.4 \\
\hline Bagasse pith(first batch) & 19.7 & 12.32 & 0.57 & 0.95 & 25 & 1.9 \\
\hline Bagasse pith (second batch) & 26.28 & 14.37 & 1.13 & 1.3 & 16 & 2.36 \\
\hline
\end{tabular}

*See Methods for Analytical Processes

A factorial design for the experiments was performed for bagasse pith and CLM to optimize the AFEX process conditions which included reaction time, reaction temperature, ammonia loading, and moisture content of the biomass. This factorial design had proven successful for determining AFEX conditions for other crop residue materials such as corn stover. The efficiency of the AFEX pretreatment was evaluated by maximum enzymatic hydrolysis achieved. Table 2 summarizes the glucose and xylose yields obtained from $72 \mathrm{hr}$ enzyme hydrolysis of these samples.

Table 2. Enzymatic Hydrolysis of AFEX-treated feedstocks $\left(100^{\circ} \mathrm{C}\right.$, $40 \%$ Loading, $2: 1$, and $30 \mathrm{~min}$ ) Ground and Unground Bagasse and CLM with 15 FPU of Spezyme Cp plus 42 units of Novo 188 per gram of Cellulose (the unground AFEX-treated samples were not ground prior to the hydrolysis)

\begin{tabular}{|c|c|c|}
\hline AFEX-treated Sample & 72 hr Glucose Yield\% & 72 hr Xylose Yield \% \\
\hline Ground bagasse & $69 \pm 2$ & $59 \pm 1$ \\
\hline Unground bagasse & $66 \pm 1$ & $57 \pm 1$ \\
\hline Ground CLM & $84 \pm 2$ & $58 \pm 2$ \\
\hline Unground CLM & $81 \pm 2$ & $61 \pm 2$ \\
\hline
\end{tabular}

As part of this task, we evaluated the effect of the particle size of the biomass on the efficiency of the AFEX treatment. Several batches of unground bagasse and CLM (particle size was about $2.5-3 \mathrm{~cm})$ were AFEX-treated $\left(100^{\circ} \mathrm{C}, 40 \%, 2: 1\right.$, and $30 \mathrm{~min}$ ). Hydrolysis results (Table 2) of these samples were similar to those of bagasse and CLM samples that were ground ( $1 \mathrm{~mm}$ pass through Mesh \#9) prior to AFEX treatment. These 
results indicate that prior grinding of biomass is not necessary for AFEX treatment of bagasse and CLM.

AFEX treatment significantly increased the digestibility of biomass. Maximum glucose and xylose yields were obtained from bagasse pith that was AFEX-treated at $100^{\circ} \mathrm{C}, 40$ or $60 \%$ moisture content, $2: 1$ ratio of ammonia loading to dry biomass for 30 min. 72 hour hydrolysis of this sample with 15 FPU of cellulase and 42 units of Novo 188 per g of cellulose resulted in $90 \%$ glucose and 70\% xylose yield. Enzyme hydrolysis of the untreated sample gave only $9 \%$ glucose yield and 3\% xylose yield. Hydrolysis data showed that digestibility of AFEX-treated bagasse pith is higher than bagasse treated under similar AFEX conditions. However, glucan content of the tested bagasse pith is lower than for bagasse. Therefore, the amount of glucose released from bagasse is higher than for bagasse pith alone.

Table 3 gives all the conditions for AFEX tested on bagasse pith. Table 3. AFEX Conditions for Pretreatment of Bagasse Pith and $72 \mathrm{hr}$ Hydrolysis Results

\begin{tabular}{|c|c|c|c|c|}
\hline \multicolumn{3}{|c|}{ AFEX CONDITIONS FOR TREATMENT OF BAGASSE PITH } & \multicolumn{2}{|c|}{$\begin{array}{l}72 \mathrm{hr} \text { hydrolysis with } 15 F P U \text { of Spezyme } \\
\text { Cp+42CBU of Novo } 188 / \mathrm{g} \text { cellulose }\end{array}$} \\
\hline TEMPERATURE & $\begin{array}{c}\text { AMMONIA } \\
\text { LOADING: BIOMASS }\end{array}$ & $\begin{array}{l}\text { MOISTURE } \\
\text { CONTENT }\end{array}$ & $\begin{array}{l}\text { GLUCOSE YIELD } \\
(\%)\end{array}$ & $\begin{array}{l}\text { Xylose yield } \\
\text { (\%) }\end{array}$ \\
\hline $100^{\circ} \mathrm{C}$ & $2: 1$ & $40 \%$ & 92 & 66 \\
\hline $100^{\circ} \mathrm{C}$ & $2: 1$ & $40 \%$ & 93 & 68 \\
\hline $100^{\circ} \mathrm{C}$ & $1: 1$ & $40 \%$ & 79 & 63 \\
\hline $100^{\circ} \mathrm{C}$ & $1: 1$ & $40 \%$ & 75 & 61 \\
\hline $90^{\circ} \mathrm{C}$ & $1: 1$ & $40 \%$ & 62 & 54 \\
\hline $90^{\circ} \mathrm{C}$ & $1: 1$ & $40 \%$ & 66 & 56 \\
\hline $90^{\circ} \mathrm{C}$ & $2: 1$ & $40 \%$ & 83 & 65 \\
\hline $100^{\circ} \mathrm{C}$ & $1: 1$ & $60 \%$ & 75 & 58 \\
\hline $100^{\circ} \mathrm{C}$ & $1: 1$ & $60 \%$ & 72 & 54 \\
\hline $90^{\circ} \mathrm{C}$ & $2: 1$ & $60 \%$ & 80 & 60 \\
\hline $90^{\circ} \mathrm{C}$ & $2: 1$ & $60 \%$ & 81 & 51 \\
\hline $90^{\circ} \mathrm{C}$ & $1: 1$ & $60 \%$ & 57 & 48 \\
\hline $90^{\circ} \mathrm{C}$ & $1: 1$ & $60 \%$ & 66 & 55 \\
\hline $100^{\circ} \mathrm{C}$ & $2: 1$ & $60 \%$ & 98 & 75 \\
\hline $100^{\circ} \mathrm{C}$ & $2: 1$ & $60 \%$ & 90 & 70 \\
\hline Untreated & & & 9 & 3 \\
\hline
\end{tabular}

Optimally AFEX-treated bagasse, pith and CLM solids were hydrolyzed using the enzyme mixtures including cellulase, $\beta$-glucosidase, and xylanase to produce $\mathrm{C} 5$ and $\mathrm{C} 6$ sugar stream. 
The enzyme cocktail for this task contained cellulase (Spezyme $\mathrm{Cp}$ ), xylanase (NS50030), and $\beta$-glucosidase (Novo 188). AFEX-treated $\left(100^{\circ} \mathrm{C}, 40 \%, 2: 1\right.$, and 30 min) bagasse, CLM and bagasse pith were hydrolyzed with several different combinations of these enzymes. Table 4 summarizes the hydrolysis results.

Table 4. Hydrolysis of AFEX-treated Bagasse, CLM and Bagasse Pith $\left(100^{\circ} \mathrm{C}, 40 \%\right.$ moisture content, 2:1 ammonia loading, $30 \mathrm{~min}$ ) with Different Combinations of Cellulase and Xylanase (Yields are calculated based on the theoretically calculated available sugar content.)

\begin{tabular}{|c|c|c|c|c|}
\hline $\begin{array}{l}\text { AFEX treated } \\
\text { biomass }\end{array}$ & $\begin{array}{c}\text { Spezyme Cp } \\
\text { (FPU), Novo } 188 \\
\text { (CBU)/g of } \\
\text { cellulose } \\
\end{array}$ & $\begin{array}{l}\text { Xylanase(NS50030) } \\
\text { ml/g dry biomass }\end{array}$ & $\begin{array}{c}72 \text { hr } \\
\text { Glucose } \\
\text { Yield (\%) }\end{array}$ & $\begin{array}{c}72 \text { hr Xylose } \\
\text { Yield (\%) }\end{array}$ \\
\hline Bagasse & 15,42 & 0 & $72 \pm 2$ & $58 \pm 2$ \\
\hline Bagasse & 15,42 & 0.2 & $82 \pm 0.2$ & $69 \pm 1$ \\
\hline Bagasse & 15,42 & 0.1 & $80 \pm 2$ & $68 \pm 1$ \\
\hline Bagasse & 15,42 & 0.05 & $83 \pm 0.5$ & $67 \pm 0.5$ \\
\hline Bagasse & 10,42 & 0.2 & $81 \pm 1$ & $74 \pm 1$ \\
\hline Bagasse & 10,42 & 0.1 & $81 \pm 0.5$ & $79 \pm 1$ \\
\hline Bagasse & 5,42 & 0.2 & $68 \pm 2$ & $74 \pm 2$ \\
\hline Bagasse & 5,42 & 0.1 & $70 \pm 1$ & $69 \pm 2$ \\
\hline CLM & 15,42 & 0 & $85 \pm 1$ & $58 \pm 0.5$ \\
\hline CLM & 15,42 & 0.2 & $85 \pm 2$ & $67 \pm 2$ \\
\hline CLM & 15,42 & 0.1 & $88 \pm 1$ & $63 \pm 1$ \\
\hline CLM & 15,42 & 0.05 & $86 \pm 2$ & $64 \pm 1$ \\
\hline CLM & 10,42 & 0.2 & $89 \pm 2$ & $62 \pm 0.5$ \\
\hline CLM & 10,42 & 0.1 & $88 \pm 1$ & $63 \pm 2$ \\
\hline CLM & 5,42 & 0.2 & $85 \pm 1$ & $62 \pm 1$ \\
\hline CLM & 5,42 & 0.1 & $81 \pm 1$ & $62 \pm 0.6$ \\
\hline Bagasse pith & 15,42 & $\mathbf{0}$ & $80 \pm 2$ & $59 \pm 2$ \\
\hline Bagasse pith & 15,42 & 0.2 & $91 \pm 2$ & $74 \pm 1$ \\
\hline Bagasse pith & 15,42 & 0.1 & $87 \pm 0.2$ & $68 \pm 0.5$ \\
\hline Bagasse pith & 15,42 & 0.05 & $83 \pm 2$ & $67 \pm 1$ \\
\hline Bagasse pith & 10,42 & 0.2 & $82 \pm 1$ & $75 \pm 2$ \\
\hline Bagasse pith & 10,42 & 0.1 & $81 \pm 3$ & $62 \pm 3$ \\
\hline Bagasse pith & 5,42 & 0.2 & $71 \pm 1$ & $65 \pm 1$ \\
\hline Bagasse pith & 5,42 & 0.1 & $70 \pm 2$ & $65 \pm 2$ \\
\hline
\end{tabular}

Presumably, xylanases improve cellulose hydrolysis by removing/hydrolyzing hemicellulose on cellulose surface, thereby increasing the accessibility of cellulose to cellulase. Hydrolysis of bagasse and bagasse pith support this concept and showed that addition of xylanase increases both glucose and xylose yields compared to hydrolysis with only cellulase. Our previous work had shown similar results for the hydrolysis of AFEX treated corn stover. However, in CLM hydrolysis addition of xylanase didn't show any significant change. 
As the data show addition of xylanase allowed us to trade off cellulase and xylanase activity without significant reduction in total released sugars. These data suggest that it is reasonable to expect incremental improvement in the hydrolysis of biomass by systematically fine tuning the cellulolytic and xylanolytic compositions of enzyme complexes for particular substrates. Having an enzyme cocktail with adequate cellulase and hemicellulase activity might help to reduce the overall enzyme loading and subsequently costs for the biomass hydrolysis.

\section{Fed batch SSF fermentation of AFEX treated CLM:}

Each of these fermentations was initiated with 10\% solid loading of AFEX-treated CLM $\left(100^{\circ} \mathrm{C}, 40 \%\right.$ moisture content, $2: 1$ ammonia loading, and 30 minutes treatment time). Enzyme loading was 20 FPU Spezyme Cp and 42 CBU of Novo 188/g cellulose. During the first $24 \mathrm{hrs}$ of the fermentation process, two more batches of biomass equal to the initial loading plus required amount of enzyme were added to the fermentors. Both fermentations were run for $120 \mathrm{hrs}$ at $\mathrm{pH}$ 5.0. The temperature was set at the optimal temperature for the microorganisms, $35^{\circ} \mathrm{C}$ for S. cerevisiae and $32^{\circ} \mathrm{C}$ for Z. mobilis. The overall biomass loading was about $21 \%$ in both fermentations. Since the temperature in the Z. mobilis fermentation was low, it took longer for the biomass to become solubilized compared to the $S$. cerevisiae fermentation.

The time course of these fermentations is presented in Figures 1 and 2 and the results are summarized in Table 5.

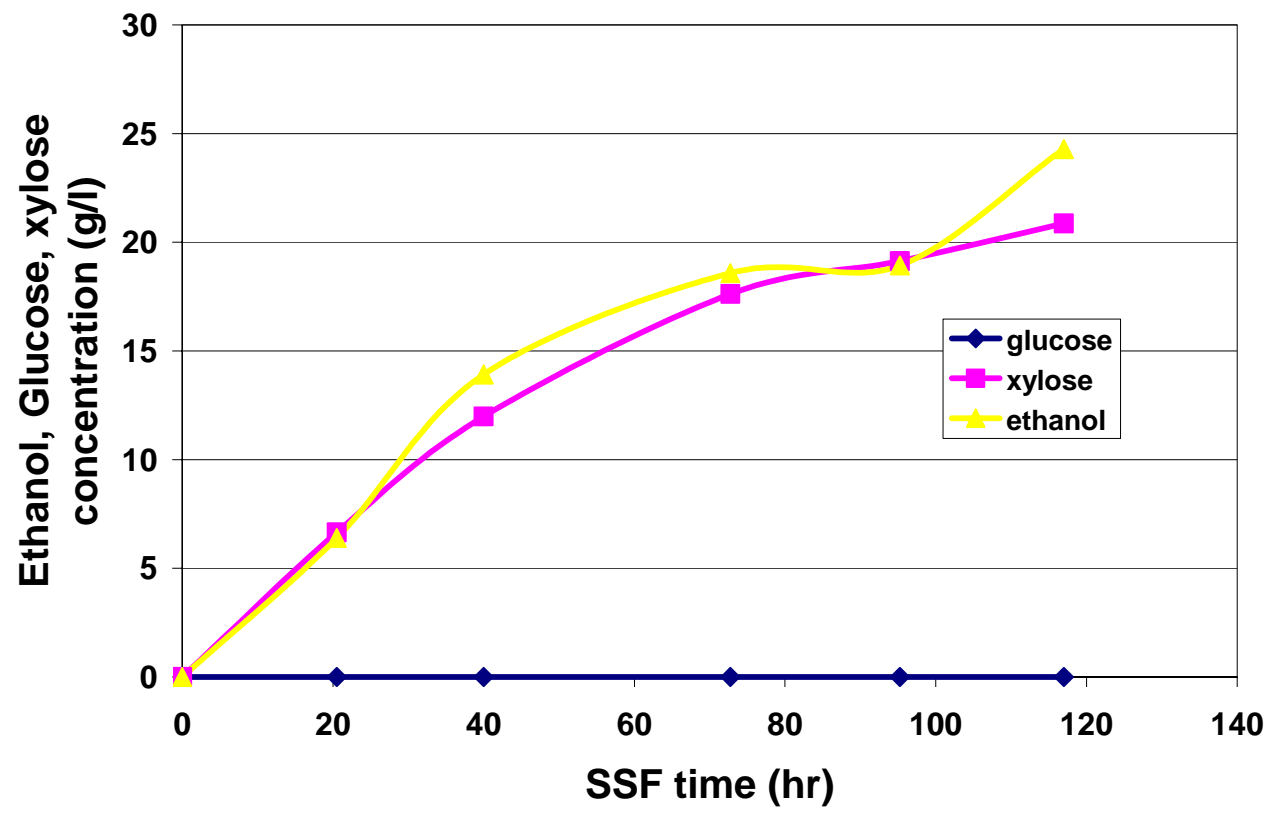

1. Time course of the fed batch SSF fermentation of AFEX treated CLM with S.

Figure cerevisiae. 


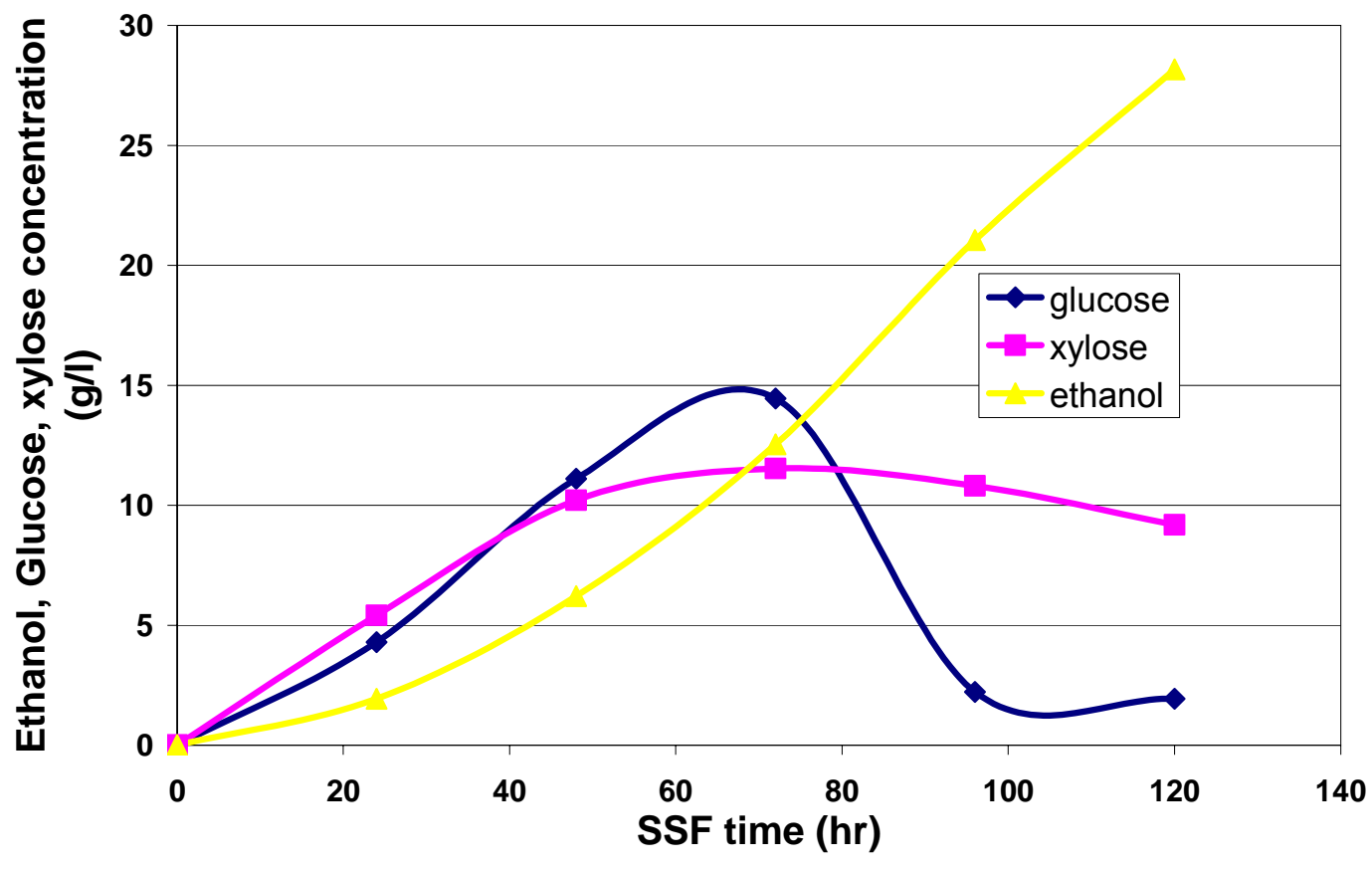

Figure 2. Time course of fed batch SSF fermentation of AFEX treated CLM with Z. mobilis. 
Table 5. Summary of the Ethanol Fed Batch SSF of AFEX-treated CLM

\begin{tabular}{|c|c|c|}
\hline Microorganism & S. cerevisiae & Z. mobilis \\
\hline Initial solid loading & $10 \%$ & $10 \%$ \\
\hline Glucan content & $31.92 \%$ & $31.92 \%$ \\
\hline Xylan content & $20.38 \%$ & $20.38 \%$ \\
\hline Initial dry solid loading (g) & 120 & 120 \\
\hline $\begin{array}{l}\text { Dry solid loading in two equal } \\
\text { separate additions (g) }\end{array}$ & 120 (in each addition) & 120 (in each addition) \\
\hline Total solid loading & 360 & 360 \\
\hline Overall solid loading & $21 \%$ & $21 \%$ \\
\hline Available Glucose (g) & 127.66 & 127.66 \\
\hline Available Xylose (g) & 83.39 & 83.39 \\
\hline Theoretical Ethanol (g)* & 65.1(from C6) & 107.64 (from C6+C5) \\
\hline Initial enzyme loading & $\begin{array}{l}20 \text { FPU Spezyme cp+ } \\
42 \text { CBU Novo 188/g } \\
\text { cellulose }\end{array}$ & $\begin{array}{l}20 \text { FPU Spezyme Cp+ } \\
42 \text { CBU Novo } 188 / \mathrm{g} \\
\text { cellulose }\end{array}$ \\
\hline Enzyme loading in each addition & $\begin{array}{l}20 \text { FPU Spezyme Cp+ } \\
42 \text { CBU Novo 188/g } \\
\text { cellulose }\end{array}$ & $\begin{array}{l}20 \text { FPU Spezyme } \mathrm{Cp}+ \\
42 \text { CBU Novo } 188 / \mathrm{g} \\
\text { cellulose }\end{array}$ \\
\hline $120 \mathrm{hr}$ glucose concentration $(\mathrm{g} / \mathrm{l})$ & 0 & 1.9 \\
\hline $120 \mathrm{hr}$ xylose concentration $(\mathrm{g} / \mathrm{l})$ & 20.8 & 8.38 \\
\hline $120 \mathrm{hr}$ ethanol titer $(\mathrm{g} / \mathrm{l})$ & 24.8 & 28.15 \\
\hline Total ethanol $(\mathrm{g})$ & 49.85 & 57.8 \\
\hline Ethanol Yield**\% & 76.57 & 53.72 \\
\hline
\end{tabular}

* Based on $0.51 \mathrm{~g}$ ethanol per gram of sugar.

** Based on obtained ethanol compared with theoretical values for ethanol.

In the $S$. cerevisiae fermentation, all the produced glucose was consumed and about 25 $\mathrm{g} / \mathrm{l}$ of ethanol was produced. Based on the available glucose in the biomass, the ethanol yield for $S$. cerevisiae fermentation was about $77 \%$. Considering that the enzyme hydrolysis of the AFEX-treated CLM at low solid loading and at $50^{\circ} \mathrm{C}$ results in about $80-85 \%$ glucose yield, the $77 \%$ ethanol yield for high solid loading was promising.

Fermentation with Z. mobilis was slower than the fermentation with S. cerevisiae. At the end of this fermentation, there was some unconsumed glucose and xylose. The final ethanol concentration reached a maximum of $28 \mathrm{~g} / \mathrm{l}$. Based on the available glucose and xylose in the biomass, the overall ethanol yield was only 54\%. The lower ethanol yield in this fermentation is presumably due to the lower temperature and also the lower efficiency of the Z. mobilis in converting both glucose and xylose to ethanol compared to the efficiency of $S$. cerevisiae for converting glucose to ethanol. However, even though the ethanol yield in the Z. mobilis fermentation was low, it is noteworthy that the total amount of generated ethanol was higher than from a similar fermentation with $S$. cerevisiae, $57.8 \mathrm{~g}$ ethanol vs. $49.87 \mathrm{~g}$ (Table 5). As our economic analysis showed, 
ethanol titer has a significant impact on the production cost and increasing the titer would improve the process economics.

Fed batch SSF fermentation of AFEX treated bagasse. Based on the CLM fed batch SSF results (mentioned above), $S$.cerevisiae was chosen for this fermentation. The fermentation was performed in a $5 \mathrm{~L}$ New Brunswick fermentor. The fermentation was run at $\mathrm{pH} 5.0$ and at $35^{\circ} \mathrm{C}$ for $120 \mathrm{hr}$. The initial solid loading was $10 \%$. Enzyme loading was 20 FPU Spezyme Cp and 42 CBU of Novo 188/g cellulose. In the first $24 \mathrm{hr}$ of the fermentation, two more batches of biomass plus required amount of enzyme were added to the fermentor. Agitation was provided with two impellers, one pitched-blade impeller at the bottom and one disk impeller at the top (submerged in the fermentation broth). The biomass was well solubilized; the mixing was adequate and the temperature was stable.

Figure 3 presents the time course of this fermentation and Table 6 summarizes the results.

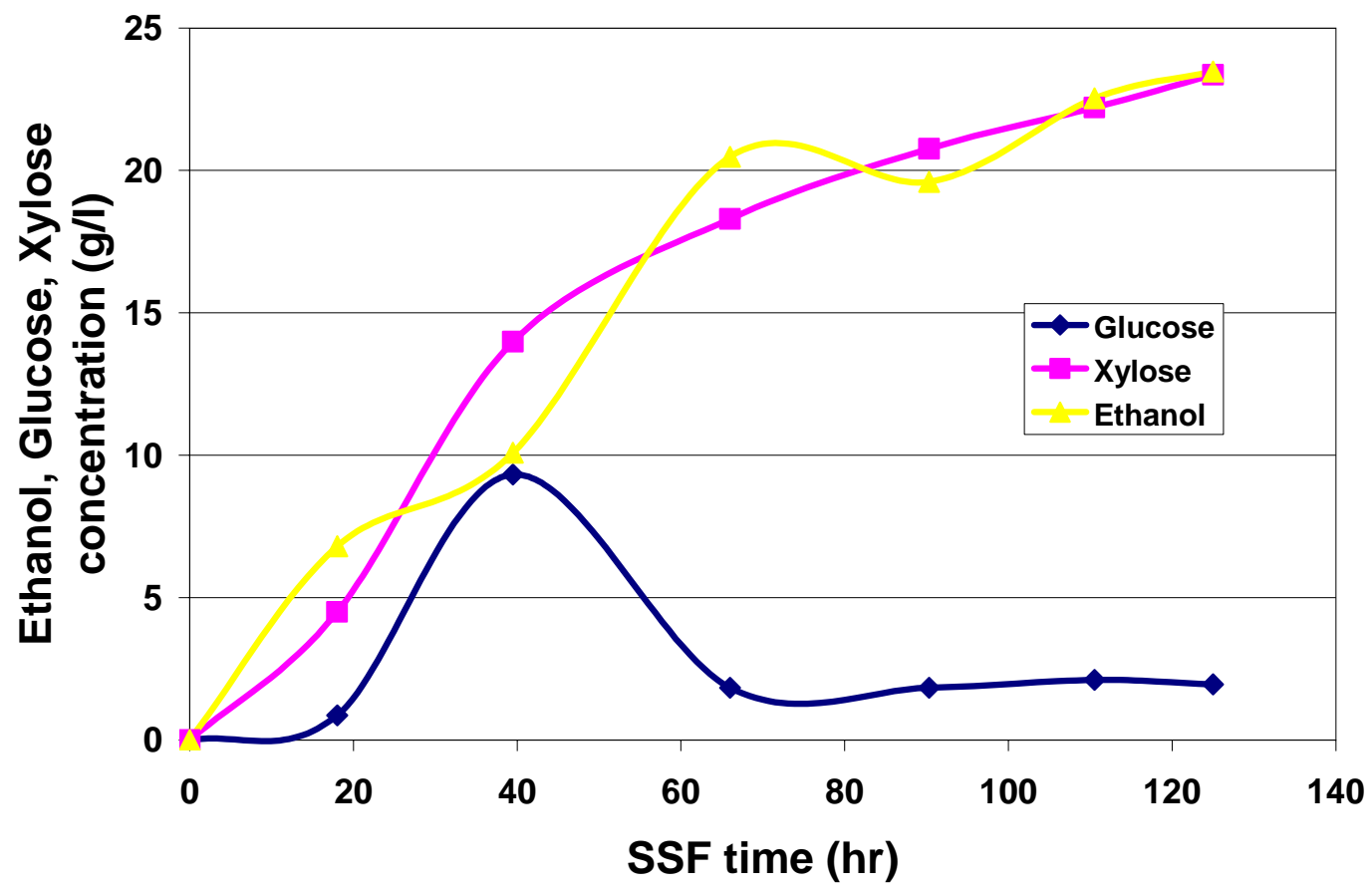

Figure 3. Time course of fed batch SSF of AFEX treated bagasse with S. cerevisiae. 
Table 6. Summary of the Fed Batch SSF Fermentation of AFEX-treated Bagasse with $S$. cerevisiae

\begin{tabular}{|c|c|}
\hline \multicolumn{2}{|c|}{$\begin{array}{l}\text { Biomass: AFEX treated bagasse }\left(100^{\circ} \mathrm{C}, 40 \% \text { moisture, } 2: 1\right. \\
\text { ammonia loading, and } 30 \mathrm{~min} .)\end{array}$} \\
\hline Microorganism & S. cerevisiae \\
\hline Initial solid loading & $10 \%$ \\
\hline Glucan content & $34.57 \%$ \\
\hline Xylan content & $18.49 \%$ \\
\hline Initial dry solid loading (g) & 300 \\
\hline $\begin{array}{l}\text { Dry solid loading in two equal } \\
\text { separate additions }(\mathrm{g})\end{array}$ & 300 (in each addition) \\
\hline Total solid loading $(\mathrm{g})$ & 900 \\
\hline Overall solid loading & $25 \%$ \\
\hline Available Glucose (g) & 345.7 \\
\hline Available Xylose (g) & 189.1 \\
\hline Theoretical Ethanol (g)* & 176.3 (from C6) \\
\hline Initial enzyme loading & $\begin{array}{l}20 \text { FPU Spezyme Cp+ } \\
42 \text { CBU Novo } 188 / \mathrm{g} \\
\text { cellulose }\end{array}$ \\
\hline Enzyme loading in each addition & $\begin{array}{l}20 \text { FPU Spezyme Cp+ } \\
42 \text { CBU Novo } 188 / \mathrm{g} \\
\text { cellulose }\end{array}$ \\
\hline $120 \mathrm{hr}$ glucose concentration $(\mathrm{g} / \mathrm{l})$ & 1.9 \\
\hline $120 \mathrm{hr}$ xylose concentration $(\mathrm{g} / \mathrm{l})$ & 23.5 \\
\hline $120 \mathrm{hr}$ ethanol titer $(\mathrm{g} / \mathrm{l})$ & 23.6 \\
\hline Total ethanol $(\mathrm{g})$ & 108 \\
\hline Ethanol Yield \%** & $61.25 \%$ \\
\hline
\end{tabular}

Almost all the generated glucose was consumed and about $24 \mathrm{~g} / 1$ ethanol was produced. Based on the available glucose in the biomass, the ethanol yield was about $61 \%$. The enzyme hydrolysis of the AFEX-treated bagasse at low solid loading and at $50^{\circ} \mathrm{C}$ resulted in about $70 \%$ glucose yield, the $61 \%$ ethanol yield for high solid loading process was encouraging. Almost complete consumption of glucose reconfirmed the absence of inhibitory compounds to the fermentation process. In this process, about $58 \%$ of the xylan was converted to xylose and produced about $109 \mathrm{~g}$ of xylose. Using a robust and efficient microorganism capable of converting both glucose and xylose to ethanol could significantly impact the overall economy of ethanol production from cellulosic material such as bagasse.

Fed batch SSF fermentation of AFEX treated bagasse pith

The fermentation was run at $\mathrm{pH} 5.0$ and at $35^{\circ} \mathrm{C}$ for $80 \mathrm{hr}$. The initial solid loading was $10 \%$. Enzyme loading was 20 FPU Spezyme Cp and 42 CBU of Novo 188/g cellulose. 
In the first $24 \mathrm{hr}$ of the fermentation, two more batches of biomass plus required amounts of enzyme were added to the fermentor. Agitation was provided with two impellers, one pitched-blade impeller at the bottom and one disk impeller at the top (submerged in the fermentation broth). The biomass was well solubilized; the mixing was adequate and the temperature was stable.

Figure 4 presents the time course of this fermentation and Table 7 summarizes the results.

Table 7. Summary of the Ethanol Fed Batch SSF of AFEX-treated Bagasse Pith

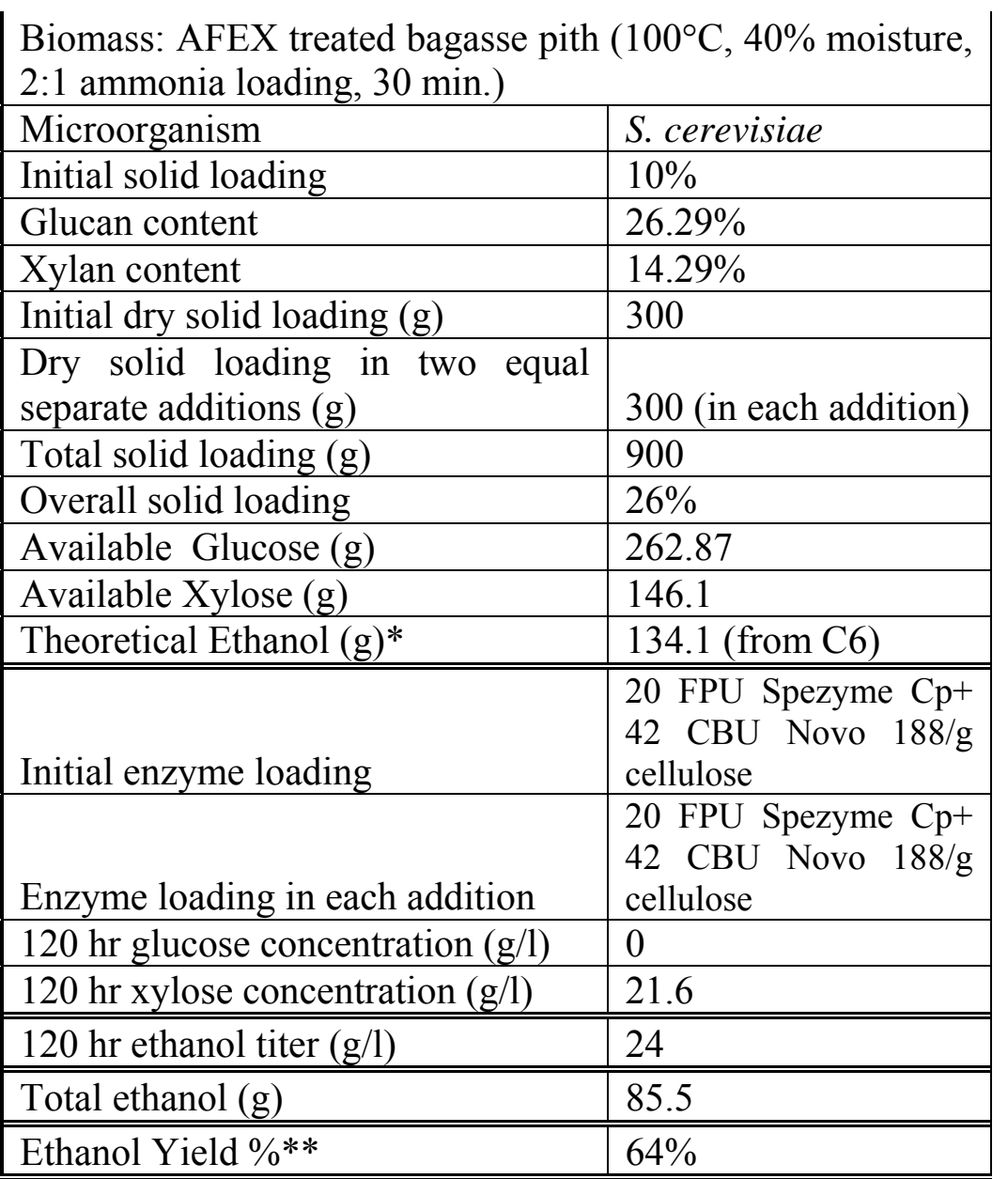

* Based on $0.51 \mathrm{~g}$ ethanol per gram of sugar.

** Based on obtained ethanol compared to theoretical ethanol. 


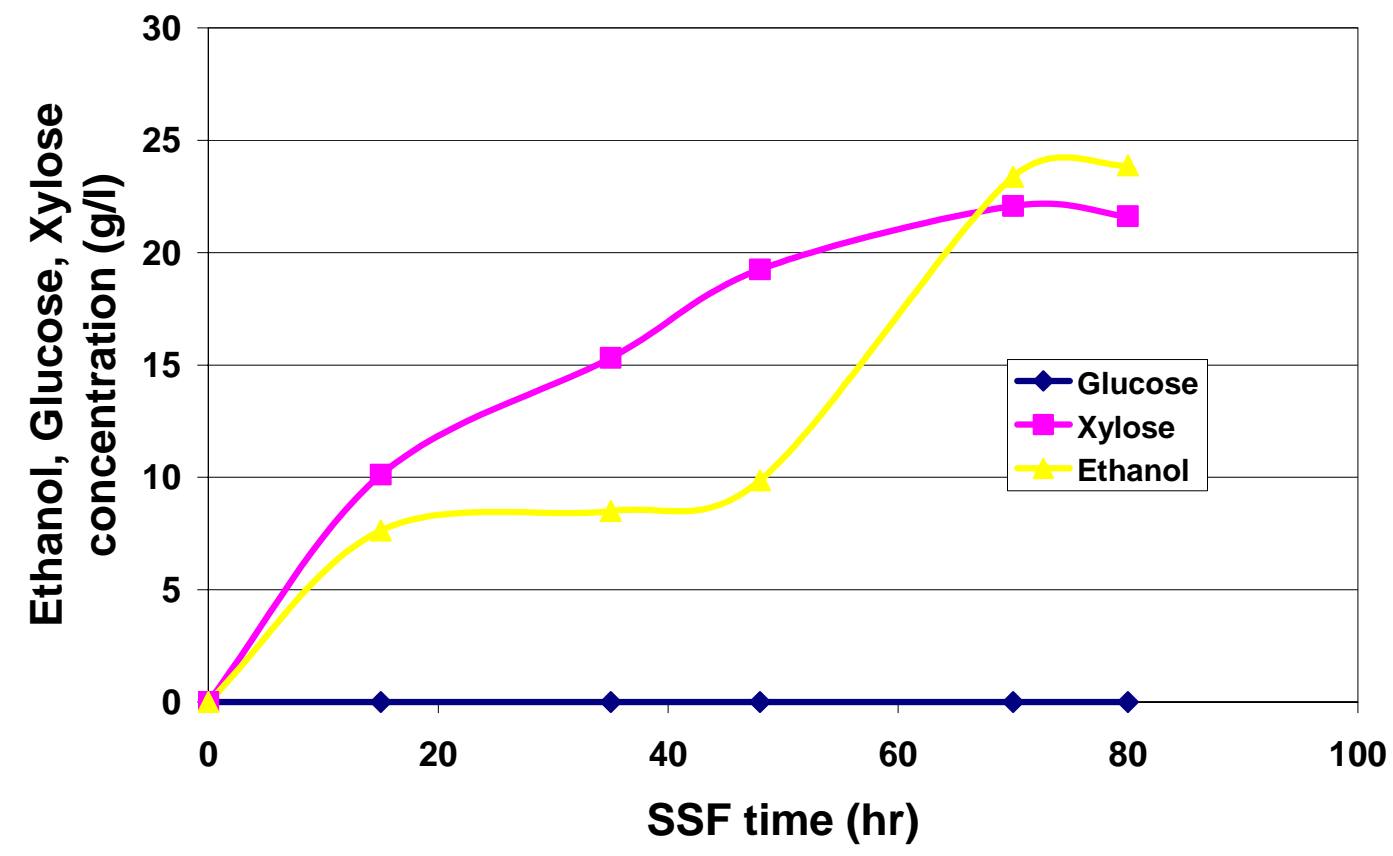

Figure 4. Time course of fed batch SSF fermentation of AFEX treated bagasse pith with S. cerevisiae.

In conclusion, these fermentations showed that the fed batch SSF fermentation of AFEXtreated biomass was feasible and resulted in higher ethanol titer compared to regular SHF fermentation. These fermentations showed that for future work a more thermo stable and more efficient microorganism that converts both $\mathrm{C} 6$ and $\mathrm{C} 5$ sugars to ethanol is needed to make the cellulosic ethanol production more efficient.

Evaluating recombinant E. coli KO11 for production of ethanol: Recombinant E. coli KO11, like Zymomonas mobilis 37821 (pZB5), utilizes both C6 and C5 sugars for ethanol production. The optimal temperature for E.coli $\mathrm{KO} 11\left(37^{\circ} \mathrm{C}\right)$ is closer to the optimal temperature of cellulase enzyme $\left(50^{\circ} \mathrm{C}\right)$ compared to that for Z. mobilis $\left(32^{\circ} \mathrm{C}\right)$. However, temperature is not the only key factor; another critical factor in SSF process is the $\mathrm{pH}$. Therefore, to find the most suitable $\mathrm{pH}$ for our SSF experiment with KO11, this microorganism was grown in the media with a mixture of sugars (glucose $+x y l o s e+$ arabinose) at three different $\mathrm{pH}$ 's $(5,6$, and 7$)$. Table 8 summarizes the optical density (OD) measurements and the sugar consumption of this microorganism at different $\mathrm{pH}$ for the course of $48 \mathrm{hr}$ of growth.

Table 8. Growth of KO11 on a Media Containing a Mixture of Sugars at Different $\mathrm{pH}$ 


\begin{tabular}{|c|c|c|c|c|c|c|}
\cline { 4 - 7 } & \multicolumn{3}{c|}{ g/l remain in the media } \\
\hline $\mathbf{p H}$ & Time, hr & OD & Glucose & Xylose & Arabinose & Total Sugar \\
\hline 5.00 & 0.00 & 0.00 & 4.17 & 2.66 & 2.02 & 8.86 \\
& 2.50 & 0.28 & 4.06 & 2.67 & 2.04 & 8.77 \\
& 4.50 & 0.70 & 3.67 & 2.67 & 1.98 & 8.33 \\
& 7.50 & 0.99 & 3.00 & 2.50 & 1.87 & 7.37 \\
& 24.00 & 0.73 & 2.05 & 2.68 & 1.95 & 6.68 \\
& 48.00 & 0.82 & 1.53 & 2.70 & 1.99 & 6.22 \\
\hline 6.00 & 0.00 & 0.00 & 4.44 & 2.75 & 2.52 & 9.71 \\
& 2.50 & 0.32 & 4.31 & 2.75 & 2.50 & 9.57 \\
& 4.50 & 1.37 & 3.68 & 2.74 & 2.33 & 8.74 \\
& 7.50 & 2.37 & 2.50 & 2.60 & 2.09 & 7.19 \\
& 24.00 & 3.11 & 0.00 & 2.59 & 0.00 & 2.59 \\
& 48.00 & 3.68 & 0.00 & 2.29 & 0.00 & 2.29 \\
\hline 7.00 & 0.00 & 0.00 & 4.21 & 2.72 & 2.91 & 9.84 \\
& 2.50 & 0.37 & 4.06 & 2.71 & 2.87 & 9.65 \\
& 4.50 & 1.66 & 3.32 & 2.69 & 2.66 & 8.66 \\
& 7.50 & 2.72 & 2.21 & 2.67 & 2.35 & 7.22 \\
& 24.00 & 3.72 & 0.00 & 2.10 & 0.00 & 2.10 \\
& 48.00 & 3.92 & 0.00 & 0.00 & 0.00 & 0.00 \\
\hline
\end{tabular}

The highest growth rate was observed at $\mathrm{pH} 7$ followed by $\mathrm{pH} 6$. As the above data suggest, xylose utilization for this microorganism is not as efficient and as fast as glucose and arabinose utilization. At $\mathrm{pH} \mathrm{7,} \mathrm{both} \mathrm{glucose} \mathrm{and} \mathrm{arabinose} \mathrm{were} \mathrm{totally}$ used up in $24 \mathrm{hr}$ of growth while xylose was consumed after $48 \mathrm{hr}$. The growth rate was slightly slower at pH 6 and after $48 \mathrm{hr}$, and some xylose still remained. pH 5 was not a favorable environment for this microorganism. Based on our previous work and the available literature, the most favorable $\mathrm{pH}$ for the cellulase enzyme is 5. Therefore, to keep both enzyme and microorganism productive, we chose $\mathrm{pH} 6$ for our SSF experiments.

An SSF experiment with AFEX-treated bagasse pith $\left(100^{\circ} \mathrm{C}, 40 \%\right.$ moisture content, $2: 1$ ammonia loading, and 30 minutes) and $\mathrm{KO} 11$ was set up in a shake flask. Fermentation was carried out with $10 \%$ solid loading, 15 FPU of cellulase and 42 units of $\beta$ glucosidase per gram of glucan, at $37^{\circ} \mathrm{C}$ and $\mathrm{pH} 6$ for $96 \mathrm{hr}$. At the end of the fermentation there was some unconsumed xylose while there was no glucose or arabinose left in the media. Based on the available sugars (glucose+xylose+arabinose), the ethanol yield was about $57 \%$. The ethanol yield was considerably lower than expected, based on our enzyme hydrolysis. Earlier enzyme hydrolysis of the AFEX-treated bagasse pith with the same enzyme loading showed $83 \%$ yield based on the available sugars (glucose+xylose+arabinose). SSF experiments are typically run at lower temperatures compared to enzyme hydrolysis and yet result in relatively higher yield. This suggests that the $\mathrm{pH}$ could be the major contributing factor for the low ethanol yield observed in this experiment. The results indicated that the E. coli was not suitable for this application. All further experimentation was conducted using Zymomonas mobilis 37821 (pZB5) and Saccharomyces cerevisiae. 
The fermentability of the generated mixed C5 and C6 sugars was evaluated via fermentation of succinic acid using Actinobacillus succinogenes (MBI strain FZ45).

The fermentability of the generated mixed sugar stream from AFEX-treated CLM was evaluated via SHF fermentation of succinic acid using Actinobacillus succinogenes (MBI strain FZ45) at two different solids loadings. Table 9 summarizes the fermentations results.

Table 9. Succinic Acid Fermentation from AFEX-treated CLM with Actinobacillus succinogenes.

\begin{tabular}{|c|c|c|}
\hline \multicolumn{3}{|c|}{ Biomass: AFEX treated CLM $\left(100^{\circ} \mathrm{C}, 40 \%\right.$ Moisture, $2: 1$ ammonia loading, $30 \mathrm{~min}$.) } \\
\hline Solid loading & $8 \%$ & $12 \%$ \\
\hline Glucan content & $27.09 \%$ & $27.09 \%$ \\
\hline Xylan content & $20.01 \%$ & $20.01 \%$ \\
\hline Dry solid loading $(g)$ & 220 & $\begin{array}{l}165 \quad \text { (less volume } \\
\text { compared to } 8 \%)\end{array}$ \\
\hline Available Glucose $(\mathrm{g})$ & 66.21 & 49.66 \\
\hline Available Xylose (g) & 50.00 & 37.51 \\
\hline \multicolumn{3}{|l|}{ Hydrolysis } \\
\hline Enzyme loading & $\begin{array}{l}20 \text { FPU Spezyme Cp } \\
+\quad 42 \text { CBU Novo } \\
188 / \mathrm{g} \text { cellulose }\end{array}$ & $\begin{array}{l}20 \text { FPU Spezyme Cp } \\
+42 \text { CBU Novo } 188 / \mathrm{g} \\
\text { cellulose }\end{array}$ \\
\hline $72 \mathrm{hr}$ hydrolysis Glucose yield & $83 \%$ & $72 \%$ \\
\hline 72 hr hydrolysis Xylose yield & $60 \%$ & $49 \%$ \\
\hline Total $\mathrm{G}+\mathrm{X}$ at $72 \mathrm{hr}(\mathrm{g})$ & 83.16 & ב54.38 \\
\hline \multicolumn{3}{|l|}{ Fermentation } \\
\hline Microorganism & A. succinogenes & A. succinogenes \\
\hline "Succinic acid at $72 \mathrm{hr}(\mathrm{g})$ & 102.3 & 63.2 \\
\hline Succinic acid titer [g/l] & 37.2 & 45.9 \\
\hline $\begin{array}{l}\text { Theor. Max., succinic acid }[\mathrm{g}] /[\mathrm{g}] \\
\text { sugar in fermentation } \\
\text { Yield: }[\mathrm{g}] \text { succinic acid/[g] biomass } \\
\text { Yield: [g] succinic acid/[g] } \\
\text { consumed sugars }\end{array}$ & $\begin{array}{l}98.7 \\
0.47 \\
1.09\end{array}$ & $\begin{array}{l}60.1 \\
0.38 \\
1.05\end{array}$ \\
\hline
\end{tabular}

Total consumption of all the generated sugars at the hydrolysis stage confirmed the absence of inhibitory compounds in the hydrolysate of AFEX-treated CLM. Lower levels of hydrolysis in the higher solid loading fermentation is most probably due to the sensitivity of the cellulase enzyme to the end product (glucose) concentration, and/or to cellobiose or to changes in the local environment as solids concentration is increased, limiting full enzymatic access to the material or adsorbing the enzymes to the substrate through pysico-chemical means. In order to lower the fermentation cost, yeast extract was replaced by LFS as the nutrient source for the fermentation. Yields of over $100 \%$ for production of succinic acid from the generated sugar from CLM are due to the fact that 
LFS contains glycerol and Actinobacillus succinogenes is also capable of converting glycerol to succinic acid.

\section{Scale -up of AFEX}

\section{Sub-Task 3. Scale up AFEX reactor from 1 gallon to 5 gallons}

MBI purchased a 5-gallon pressure reactor from Parr Instrument Company to replace the 1-gallon reactor currently being used for the AFEX process. The 5-gallon reactor is made out of T316 stainless steel with following specifications:

1. With $120 \mathrm{in} / \mathrm{lb}$ footless magnetic stirrer

2. With PTFE gasket and split ring closure

3. Head to include $0-1000$ psi gage, 1000 psi rupture disk, double valve gas release valve and thermowell with thermocouple, back to back anchor stirrer with PTFE wiper blades

4. Variable speed motor $0-180 \mathrm{rpm}$

5. Flexible mantle heater

6. Fixed head style vessel mounted in custom support stand for either vertical or horizontal operation with pneumatic controls

7. Programmable temperature control

The 1-gallon reactor, the 5-gallon reactor and the pump set-ups were rearranged so that both reactors could be connected to the pump to allow simultaneous use of both reactors. The 1-gallon reactor operates only in a vertical position and is equipped with an anchorshaped stirrer that reaches the bottom of the reactor. With the 5-gallon reactor, we are limited to being able to stir and AFEX-treat approximately $150 \mathrm{~g}$ of bagasse or CLM. However, the 5-gallon reactor can be operated in either the vertical or horizontal positions. The reactor is loaded and unloaded in a vertical position and rotates to horizontal for the stirring operation. The stirrer has a special design (back-to-back anchor) which provides better mixing. Initially, $750 \mathrm{~g}$ of bagasse was treated at the optimal conditions identified for the AFEX treatment of bagasse $\left(100^{\circ} \mathrm{C}, 40 \%\right.$ moisture content, 2:1 ammonia:biomass, and $30 \mathrm{~min}$ ) in the 1-gallon reactor. The temperature was well controlled and the biomass was stirred in the horizontal position. The final pressure was approximately $450-500 \mathrm{psi}$, similar to that seen in the 1-gallon reactor. After 30 minutes of treatment, the reactor was rotated back to the vertical position and the pressure was released (releasing pressure took longer than the 1-gallon reactor.). The AFEXtreated biomass was unloaded and left under a fume hood to volatize the remaining ammonia. The treated sample did not appear well mixed; some patches of the biomass were lighter in color compared with the rest of the biomass. The treated sample was enzymatically hydrolyzed to evaluate the AFEX efficiency. The hydrolysis results are summarized in Table 10. The glucose and xylose yields were slightly lower compared to samples treated in the 1-gallon reactor under the same conditions. 
To provide better mixing and ammonia distribution, the Teflon blades on the mixer were extended and a dip tube was added to the ammonia feeding port. After implementing these modifications, the reactor was run with $600 \mathrm{~g}$ biomass instead of $750 \mathrm{~g}$. The sample generated from this run was more homogenous than those of the previous runs. The hydrolysis data showed slightly higher glucose and xylose yields (Table 10), similar to yields from the 1-gallon reactor; however, the mixing still was not satisfactory. To insure a better mixing pattern, the lower anchor was modified with two extension rods extending downward on the opposite sides of the main shaft. The rods have tines perpendicularly welded on them to provide a pitchfork-like action for mixing the biomass. Then $600 \mathrm{~g}$ of bagasse was pretreated with the modified mixer. The treated sample was more thoroughly mixed than the earlier samples. The hydrolysis results were similar to the hydrolysis result from the 1-gallon reactor. The AFEX run was performed in duplicate, and the hydrolysis in quadruples. The results are reported as the average.

Table 10. Hydrolysis Results of Bagasse Treated in the 5-gallon Reactor

\begin{tabular}{|c|c|c|c|c|c|c|c|c|}
\hline $\begin{array}{c}\text { AFEX } \\
\text { ID\# }\end{array}$ & $\begin{array}{c}\text { Biomass } \\
\text { g }\end{array}$ & Stirrer & Temperature & $\begin{array}{c}\text { \% } \\
\text { Moisture }\end{array}$ & $\begin{array}{c}\text { Time } \\
\text { Min. }\end{array}$ & $\begin{array}{c}\text { Ammonia } \\
\text { loading }\end{array}$ & $\begin{array}{c}\text { Glucose } \\
\text { yield \% }\end{array}$ & $\begin{array}{c}\text { Xylose } \\
\text { yield \% }\end{array}$ \\
\hline $\begin{array}{c}\text { 831- } \\
\text { 99A }\end{array}$ & 750 & original & $100^{\circ} \mathrm{C}$ & 40 & 30 & $2: 1$ & $64 \pm 1$ & $49 \pm 2$ \\
\hline $\begin{array}{c}831- \\
100 A\end{array}$ & 750 & original & $100^{\circ} \mathrm{C}$ & 40 & 30 & $2: 1$ & $65 \pm 2$ & $48 \pm 2$ \\
\hline $\begin{array}{c}853- \\
16 \mathrm{~A}\end{array}$ & 600 & modified & $100^{\circ} \mathrm{C}$ & 40 & 30 & $2: 1$ & $70 \pm 2$ & $56 \pm 1$ \\
\hline $\begin{array}{c}853- \\
17 \mathrm{~A}\end{array}$ & 600 & modified & $100^{\circ} \mathrm{C}$ & 40 & 30 & $2: 1$ & $69 \pm 2$ & $54 \pm 2$ \\
\hline $\begin{array}{l}1 \text { gallon } \\
\text { reactor }\end{array}$ & 150 & original & $100^{\circ} \mathrm{C}$ & 40 & 30 & $2: 1$ & $70 \pm 2$ & $58 \pm 2$ \\
\hline
\end{tabular}

To optimizethe AFEX conditions and the reactor setting, more runs needed to be performed. However at this point of the project the heater on the 5-gallon reactor failed. After the repair (which took approximately a month), a few more AFEX runs were conducted to verified the results obtained above. Data in Table 11 shows the reproducibility of these results. We have also treated bagasse under similar conditions with the exception that the run time was increased from 30 minutes to 45 minutes (85322A). Hydrolysis results for this run exhibited higher glucose and xylose yields compared to the sample treated for 30 minutes. These results were verified through repeat runs and, as Table 2 shows, the improvement is not significant. AFEX runs of bagasse with $60 \%$ moisture content have also been attempted and the hydrolysis data has not shown any improvement. Bagasse sample treated at $60 \%$ moisture content at $100^{\circ} \mathrm{C}$ and $2: 1$ ammonia loading for 45 minutes gave a similar glucose yield $(70 \% \pm 1)$ compared to a sample treated with $40 \%$ moisture content. Lower hydrolysis yields were demonstrated when the ammonia loading was lowered.

Further fine tuning of the stirrer and the overall operation, has enabled us to treat 750 grams of biomass per run, versus the 600 grams of biomass previously treated. The 
treated biomass were well mixed and showed similar hydrolysis results to the AFEX run performed with 600 grams of biomass.

Table 11. 72-hr Hydrolysis Results of Bagasse Treated in the 5-gallon Reactor. )Yields are calculated based on the available sugars. Hydrolyses were conducted with 15 FPU of cellulase and 42 units of Novo-188 per gram of cellulose.)

\begin{tabular}{|c|c|c|c|c|c|c|c|}
\hline $\begin{array}{c}\text { AFEX } \\
\text { ID\# }\end{array}$ & Biomass g & Temperature & $\begin{array}{c}\% \\
\text { Moisture }\end{array}$ & $\begin{array}{c}\text { Time } \\
\text { Min. }\end{array}$ & $\begin{array}{c}\text { Ammonia } \\
\text { loading }\end{array}$ & $\begin{array}{c}\text { Glucose } \\
\text { yield \% }\end{array}$ & $\begin{array}{c}\text { Xylose } \\
\text { yield \% }\end{array}$ \\
\hline $853-16 \mathrm{~A}$ & 600 & $100^{\circ} \mathrm{C}$ & 40 & 30 & $2: 1$ & $70 \pm 2$ & $56 \pm 1$ \\
\hline $853-21 \mathrm{~A}$ & 600 & $100^{\circ} \mathrm{C}$ & 40 & 30 & $2: 1$ & $69 \pm 1$ & $55 \pm 1$ \\
\hline $853-26 \mathrm{~A}$ & 600 & $100^{\circ} \mathrm{C}$ & 40 & 30 & $2: 1$ & $67 \pm 1$ & $50 \pm 1$ \\
\hline $853-22 \mathrm{~A}$ & 600 & $100^{\circ} \mathrm{C}$ & 40 & 45 & $2: 1$ & $78 \pm 2$ & $56 \pm 2$ \\
\hline $\begin{array}{c}853- \\
\text { 29A }\end{array}$ & 600 & $100^{\circ} \mathrm{C}$ & 40 & 45 & $2: 1$ & $68 \pm 1$ & $50 \pm 2$ \\
\hline $853-25 \mathrm{~A}$ & 600 & $100^{\circ} \mathrm{C}$ & 40 & 45 & $2: 1$ & $72 \pm 1$ & $54 \pm 1$ \\
\hline $853-25 B$ & 600 & $100^{\circ} \mathrm{C}$ & 40 & 45 & $2: 1$ & $70 \pm 1$ & $53 \pm 1$ \\
\hline $853-30 \mathrm{~A}$ & 750 & $100^{\circ} \mathrm{C}$ & 40 & 45 & $2: 1$ & $70 \pm 3$ & $46 \pm 2$ \\
\hline $853-26 B$ & 600 & $100^{\circ} \mathrm{C}$ & 40 & 30 & $1.5: 1$ & $61 \pm 1$ & $49 \pm 1$ \\
\hline $\begin{array}{l}853-27 \mathrm{~A} \\
\text { 8 gallon }\end{array}$ & 600 & $100^{\circ} \mathrm{C}$ & 40 & 30 & $1.5: 1$ & $56 \pm 2$ & $45 \pm 2$ \\
\hline
\end{tabular}

Previous years research showed that in the 1-gallon reactor, the most effective AFEX conditions for the treatment of CLM were $100^{\circ} \mathrm{C}, 40 \%$ moisture content, $2: 1$ ammonia to biomass loading for 30 minutes. These conditions were evaluated in the 5-gallon reactor and gave similar hydrolysis results to the sample treated in the 1-gallon reactor. Lower hydrolysis yields were demonstrated when the ammonia loading was lowered. When a longer treatment time (45 minutes) was evaluated, the hydrolysis yields were similar to those from runs conducted at 30 minutes. The hydrolysis data and the applied AFEX conditions are summarized in Table 12.

Table 12. 72-hr Hydrolysis Results of CLM Treated in the 5-gallon Reactor. (Yields are calculated based on the available sugars. Hydrolyses were conducted with 15 FPU of cellulase and 42 units of Novo-188 per gram of cellulose.) 


\begin{tabular}{|l|l|l|l|l|l|l|l|}
\hline $\begin{array}{l}\text { AFEX } \\
\text { ID\# }\end{array}$ & Biomass g & Temperature & $\%$ & $\begin{array}{l}\text { Time } \\
\text { Moisture }\end{array}$ & $\begin{array}{l}\text { Minmonia } \\
\text { loading }\end{array}$ & $\begin{array}{l}\text { Glucose } \\
\text { yield \% }\end{array}$ & $\begin{array}{l}\text { Xylose } \\
\text { yield \% }\end{array}$ \\
\hline $853-23 \mathrm{~A}$ & 600 & $100^{\circ} \mathrm{C}$ & 40 & 30 & $2: 1$ & $85 \pm 1$ & $51 \pm 1$ \\
\hline $853-24 \mathrm{~A}$ & 600 & $100^{\circ} \mathrm{C}$ & 40 & 45 & $2: 1$ & $83 \pm 1$ & $50 \pm 1$ \\
\hline $853-28 \mathrm{~A}$ & 600 & $100^{\circ} \mathrm{C}$ & 40 & 30 & $2: 1$ & $83 \pm 1$ & $49 \pm 1$ \\
\hline $853-33 \mathrm{~A}$ & 750 & $100^{\circ} \mathrm{C}$ & 40 & 30 & $2: 1$ & $79 \pm 1$ & $51 \pm 1$ \\
\hline $853-28 \mathrm{~B}$ & 600 & $100^{\circ} \mathrm{C}$ & 40 & 30 & $1.5: 1$ & $77 \pm 1$ & $46 \pm 1$ \\
\hline $\begin{array}{l}1 \text { gallon } \\
\text { reactor }\end{array}$ & $150 \mathrm{~g}$ & $100^{\circ} \mathrm{C}$ & 40 & 30 & $2: 1$ & $84 \pm 2$ & $58 \pm 2$ \\
\hline
\end{tabular}

The AFEX treatment of bagasse and CLM at $100^{\circ} \mathrm{C}, 40 \%$ moisture content, 2:1 ammonia loading for 30 minutes was repeated. The hydrolysis results verified that the most effective conditions for AFEX treatment of bagasse and CLM in the 5-gallon reactor are the same as conditions identified for the 1-gallon reactor.

\section{Materials and Methods (Task 1)}

Materials:

Sugarcane bagasse, bagasse pith and CLM were provided by Audubon Sugar Institute (ASI). They were milled by knife mill (Fitzmill Model JT) to pass through a $1 \mathrm{~mm}$ screen (Mesh \#9). The composition of the bagasse, bagasse pith and CLM are summarized in Table 1.

Cellulase: Spezyme Cp (Genencor, Rochester, NY).

$\beta$-glucosidase: Novozyme 188 (Sigma, St. Louis, MO)

Xylanase: NS50014 and NS50030 (Novozyme, Franklinton; NC), NS50030 activity: 500

FXU/g (FXU: Fungal Xylanase Unit); activity of NS50014: $750 \mathrm{FXU/g}$; density of both enzymes is $1.08 \mathrm{~g} / \mathrm{ml}$.

Anhydrous ammonia: Linde Gas LLC, (Lansing, MI). All other chemicals were purchased from Sigma (St. Louis, MO).

Analytical methods:

Composition (glucan, xylan, galactan, arabinan, lignin and ash) of the biomass was determined by following the National Renewable Energy Laboratory (NREL) procedure, (NREL LAP-002). NREL procedures are available at:

http://www.ott.doe.gov/biofuels/analytical_methods.html.

Extractive content was measured according to NREL procedure LAP-010. 
Enzymatic hydrolysis was carried out by following the NREL LAP-009 procedure. Hydrolysate samples were analyzed for glucose, xylose, cellobiose, arabinose, mannose and galactose content by HPLC, using an Aminex-HPX-87P column (Bio-Rad). All hydrolyses were performed in duplicate and the data are presented as the average of the duplicates.

Selective hydrolysis of hemicellulose by cellulase-free xylanase: Hydrolyses were performed according to NREL LAP-009 with the exception of replacing the cellulase with xylanase. The detail of loading is presented in the Results section. All experiments were performed in duplicate and the data are presented as the average of the duplicates.

\section{AFEX treatment:}

The biomass (bagasse, bagasse pith, and CLM) was treated by the AFEX process in a one-gallon pressure reactor (PARR). Biomass with the desired moisture content level was added to the reactor. To ensure uniform distribution of heat and ammonia, the reactor was equipped with an agitator and mixed the biomass at a speed of 100rpm during the entire process. The reactor was heated by means of an electrical heating mantel. While the reactor was heating, the desired amount of ammonia was pumped into the reactor. The reaction timer was started when the reactor was within $5^{\circ} \mathrm{C}$ of the set-point. When the desired reaction time elapsed, ammonia was quickly evacuated via a manual ball valve. The treated biomass was removed from the reactor and left in a fume hood to evaporate the residual ammonia. The treated biomass was stored at $4{ }^{\circ} \mathrm{C}$ until used. All AFEX runs were performed in duplicate and data are presented as the average of the duplicates.

Succinic acid production from AFEX treated CLM and bagasse via separate hydrolysis and fermentation (SHF):

AFEX-treated biomass for two different solids loadings (8 and 12\% for CLM, 8 and 12\% for bagasse) was combined with $125 \mathrm{~g} / 1$ of liquid feed syrup [LFS] (GPC, Muscatine IA) and the volume adjusted to nearly final fermentation volume with water. The fermentation vessels (5L BioFloIII fermentor) containing the biomass and LFS were sterilized for $60 \mathrm{~min}$ at $121^{\circ} \mathrm{C}, 19 \mathrm{psi}$ pressure, cooled to and maintained at $50^{\circ} \mathrm{C}$. The $\mathrm{pH}$ of the biomass/ LFS slurries was determined and adjusted to a $\mathrm{pH} 5.1$ through the addition of $8 \mathrm{~N} \mathrm{H}_{2} \mathrm{SO}_{4}$. Only minor $\mathrm{pH}$ adjustments were necessary. Enzymes (20 FPU Spezyme Cp +42 CBU Novo 188/g cellulose)were filter sterilized and added to the fermentor, but no further $\mathrm{pH}$ adjustments were necessary over the course of the 72 hour hydrolysis. Samples were taken every 24 hours for monitoring the hydrolysis of AFEXtreated CLM. Samples were analyzed for sugars by HPLC using refractive index detection and an Aminex HPX-87P column with a de-ashing guard column, held at room temperature. After 72 hours of the hydrolysis, the $\mathrm{pH}$ was brought to 6.9 via the addition of $\mathrm{Mg}(\mathrm{OH})_{2} / \mathrm{Na}_{2} \mathrm{CO}_{3}$ and bringing the temperature to $38^{\circ} \mathrm{C}$. Fomenters were inoculated with a 5\% seed inoculums. Seed was raised in a medium containing: $80 \mathrm{~g} / 1$ glucose, 85 $\mathrm{g} / 1$ LFS, $3 \mathrm{~g} / 1$ yeast extract, $0.2 \mathrm{mg} / \mathrm{l}$ d-biotin and $5 \mathrm{mM}$ phosphate. The $\mathrm{pH}$ was maintained at 7.0 with $\mathrm{Mg}(\mathrm{OH})_{2}$. Agitation was set at $250 \mathrm{rpm}$, temperature at $38^{\circ} \mathrm{C}$ and carbon dioxide was spurge at a rate of 0.025 v.v.m. The seed was grown for about 13 hours and until the $\mathrm{OD}_{660}$ was 2.84. After inoculating the fermenters, the fermentations 
were carried out for 72 hours. The fermentations were monitored by analyzing the $24 \mathrm{hr}$ samples for succinic acid, glucose, lactic acid, pyruvate, ethanol, and formic acid concentrations. These components were determined by reverse phase high pressure liquid chromatography (HPLC) using a Waters 1515 isocratic pump with a Waters 717 Auto sampler and a Waters 2414 refractive index detector set at $35^{\circ} \mathrm{C}$. The HPLC system was controlled, data collected and processed using Waters Breeze software (version 3.3). A Bio-Rad Aminex HPX-87H (300mm x 7.8mm) column was used with a cation $\mathrm{H}$ guard column held at $55^{\circ} \mathrm{C}$. The mobile phase was $0.021 \mathrm{~N}$ sulfuric acid running at $0.5 \mathrm{ml} / \mathrm{min}$. Samples were filtered through a $0.45 \mu \mathrm{m}$ filter, and $5.0 \mu 1$ were injected onto the column. Run time was thirty minutes.

A mass flow controller (Brooks model 5850I) was used to monitor and supply $\mathrm{CO}_{2}$ to the fermenter sparging system at $100 \mathrm{ml} / \mathrm{min}$. A mass flow meter (Brooks model 5860I) was used to measure $\mathrm{CO}_{2}$ exiting the fermentation vessel by way of the exhaust condenser system. The two $\mathrm{CO}_{2}$ flow meters were connected to a computer via a 4-20ma BioCommand Interface. The BioCommand Plus Bioprocessing software logs the inlet and outlet $\mathrm{CO}_{2}$ flow every 60 seconds. The rate of $\mathrm{CO}_{2}$ consumption $(\mathrm{ml} / \mathrm{min})$ was expressed as the difference between the inlet and outlet rates during any given minute $\left(\mathrm{CO}_{2 \text { use }}=\right.$ $\left.\mathrm{CO}_{2 \text { in }}-\mathrm{CO}_{2 \text { out }}\right)$. The moles of $\mathrm{CO}_{2}$ consumed were calculated using the Ideal Gas Law, ( 0.88694 liters $\div 22.4$ liters $/$ mole $=0.0396$ moles $)$. The mass flow meters were calibrated by the manufacturer for $\mathrm{CO}_{2}$ and their precision is $1 \%$ of full scale or $2 \mathrm{ml} / \mathrm{m}$. The fermentation setup was monitored for gas leaks, by mixing 5\% hydrogen into the $\mathrm{CO}_{2}$. Hydrogen leaks are detected using a Tif8800 CO/Combustible Gas analyzer.

Ethanol production from AFEX bagasse via separate hydrolysis and fermentation (SHF): Enzyme cocktail: 20 FPU of Spezyme Cp and 42 CBU of Novozyme 188 /g cellulose.

Inoculum preparation: Zymomonas mobilis pZB5 was used for SHF fermentations. The medium for the SHF fermentations contained $5 \mathrm{~g} / 1$ Bacto yeast extract, $2 \mathrm{~g} / 1 \mathrm{KH} 2 \mathrm{PO} 4,30$ $\mathrm{mg} / 1$ tetracycline-HCL, $50-100 \mathrm{~g} / \mathrm{l}$ biomass weight. The inoculum was grown in the same medium with $2 \% \mathrm{w} / \mathrm{v}$ glucose and $1 \%$ xylose as substrate. The growth in the inoculum flasks was monitored by measuring the optical density. They were used to inoculate the fermenters when the $\mathrm{OD}_{600}$ reached 2.5-3.0.

Bioreactor preparations: The fermentors were autoclaved for $30 \mathrm{~min}$ prior loading. The appropriate amounts of biomass for $4 \%$ (in $5 \mathrm{~L}$ BioFloIII fermentor) and $8 \%$ (in $2.5 \mathrm{~L}$ BioFloIII) solids loading along with the required amount of water and medium were added to the fermentors. The fermentors were operated at $50^{\circ} \mathrm{C}, 500 \mathrm{rpm}$ and $\mathrm{pH} 5.0$ and the separate hydrolysis stage was started by adding the enzyme cocktail. The hydrolyses were carried out for $72 \mathrm{hrs}$ and samples were taken every 24 hours. After the hydrolyses, the fermentors were operated at $28^{\circ} \mathrm{C}, 500 \mathrm{rpm}$ and $\mathrm{pH} 5.0$ and the SHF fermentations were started by adding $5.8 \%$ inoculum of Z. mobilis pZB5. The fermentations were carried out for $72 \mathrm{hrs}$ and samples were taken every 24 hours. Sugars concentrations were determined by HPLC using standard methods for the BioRad Aminex HPX-87P column. Ethanol and organic acid byproduct were determined by HPLC using standard methods for the BioRad Aminex HPX-87H column. 
Fed batch SSF ethanol fermentation with Saccharomyces cerevisiae:

Enzyme preparations: An enzyme cocktail was made for each fermentor and Spezyme Cp (20 FPU/g cellulose) and Novo 188 (42 CBU/g cellulose) were added. The enzyme cocktail was filter sterilized with a $50 \mathrm{~mm}$ pre-sterilized $0.2 \mu \mathrm{m}$ filtration unit (www.nalgenelabware.com).

Medium and inoculum preparations: A Saccharomyces cerevisiae strain obtained from NREL was used. The medium used in the SSF fermentations contained corn steep liquor (CSL) $5 \% \mathrm{v} / \mathrm{v}, 0.62 \mathrm{~g} / 1 \mathrm{MgSO}_{4} .7 \mathrm{H}_{2} \mathrm{O}, 2 \mathrm{~g} / 1 \mathrm{NH}_{4} \mathrm{SO}_{4}$. The inoculum was grown in the same medium as used in the SSF fermentations, but with $2 \% \mathrm{w} / \mathrm{v}$ glucose as substrate. The inoculum was grown in $1000 \mathrm{ml}$ baffled Erlenmeyer flasks containing $150 \mathrm{ml}$ of medium each. The flasks were incubated at $30^{\circ} \mathrm{C}$ and $150 \mathrm{rpm}$ in a Model G25 incubator shaker (NBS, Edison, NJ). The growth in the inoculum flasks was monitored by measuring the optical density. They were used to inoculate the fermentors when the $\mathrm{OD}_{600}$ reached 2.5-3.5, after about 14-15 hours of incubation.

Bioreactor preparations: The amount of biomass necessary to give a $10 \%$ solids loading was placed into 3 or $5 \mathrm{~L}$ fermentor (NBS, Edison, NJ), with the required amount of water containing the CSL and the medium salts. The fermentors were autoclaved for 1 hour. After autoclaving, the fermentors were operated at $35^{\circ} \mathrm{C}, 700 \mathrm{rpm}$, and $\mathrm{pH} 5.0$. The $\mathrm{pH}$ was controlled through the automatic addition of $1 \mathrm{M} \mathrm{NaOH}$, and $4 \mathrm{~N} \mathrm{H}_{2} \mathrm{SO}_{4}$. The $\mathrm{pH}$ of the fermentation was monitored by checking the sample $\mathrm{pH}$ using an externally calibrated electrode and adjusting the fermentor automatic $\mathrm{pH}$ controller as necessary. The SSF fermentation was started by adding $150 \mathrm{ml}$ of enzyme cocktail and $150 \mathrm{ml}$ of $S$. cerevisiae inoculum. The target amount of biomass was three times of the starting loading; therefore, in the first $24 \mathrm{hrs}$ of the process, two more batches of biomass (each equal to the initial loading) plus the required amount of enzyme cocktail were separately added to the fermentor. Fermentation was carried out for $120 \mathrm{hr}$ and samples were taken for sugar and ethanol analysis every 24 hours.

Fed batch SSF ethanol fermentation with Zymomonas mobilis:

This fermentation was similar to the fermentation mentioned above with the following exception:

Inoculum preparation: The medium for the SSF fermentations contained $5 \mathrm{~g} / 1$ Bacto yeast extract, $2 \mathrm{~g} / 1 \mathrm{KH} 2 \mathrm{PO} 4,30 \mathrm{mg} / 1$ tetracycline-HCL. The inoculum was grown in the same medium with $2 \% \mathrm{w} / \mathrm{v}$ glucose and $1 \%$ xylose as substrate. Growth in the inoculum flasks was monitored by measuring the optical density at $600 \mathrm{~nm}$. Inoculum flasks were used to inoculate the fermentors when the $\mathrm{OD}_{600}$ reached 2.5-3.0.

The fermentor was operated at $32^{\circ} \mathrm{C}, 700 \mathrm{rpm}$, and $\mathrm{pH} 5.0$ with $10 \%$ solids loading. The $\mathrm{pH}$ was controlled through the automatic addition of $1 \mathrm{M} \mathrm{NaOH}$, and $4 \mathrm{~N}_{2} \mathrm{SO}_{4}$. The SSF fermentation was initiated by adding $150 \mathrm{ml}$ of enzyme cocktail and $150 \mathrm{ml}$ of $Z$. mobilis inoculum. The target amount of biomass was three times of the starting loading; therefore, in the first $24 \mathrm{hr}$ of the process, two more batches of biomass (each equal to the 
initial loading) plus the required amount of enzyme cocktail were separately added to the fermentor. Fermentation was carried out for $120 \mathrm{hr}$ and every 24 hours samples were taken for sugar and ethanol analysis.

Fed batch SSF fermentation of AFEX treated CLM: Two different microorganisms, S. cerevisiae and Z. mobilis 37821 (pZB5) were used for the fed batch SSF fermentation of AFEX-treated CLM. These fermentations were performed in 3L New Brunswick Microferm fermentorsAgitation in both fermentors was provided by three impellers with the same set up (one pitched-blade impeller at the bottom and two disk impellers on the top). In general, the mixing appeared adequate to maintain solids in a suspended slurry.

\section{Task 2. Alkaline treatment, solid/liquid separation and Lignin recovery}

The goal of this task was to investigate the effects of post- AFEX extractions on biomass. The concentration was on a second extraction with caustic (or water). Monitoring was by enzyme digestion. Several other methods were tried, on both AFEX and non-AFEX treated materials, but these results are subject of a different contract.

\section{Results}

Biomass Analysis

The key to this task is biomass analysis. Analytical methods developed or utilized by ASI, MBI and NREL were compared to establish the composition of the various test materials. Table 13 compares the compositions of pith, CLM, and bagasse determined at ASI and MBI. The glucan content of pith agreed within $\%$ for ASI and MBI. For CLM, ASI measured a slightly lower hemicellulose and cellulose content than, however lignin content agreed within $1 \%$ and extractives agreed with those of published literature within $2 \%$.

Table 13: Compositional analysis of sugar cane biomass. Weight percent (g/100 $\mathrm{g}$ dry matter).

\begin{tabular}{|l|c|c|c|c|c|c|}
\hline \multicolumn{1}{|c|}{ Substrate } & Hemicellulose & Cellulose & Lignin & Ash & Extractives & Total \\
\hline \hline Pith (ASI) & $16.7 \%$ & $17.3 \%$ & $44.1 \%$ & $20.9 \%$ & $4.6 \%$ & $103.5 \%$ \\
\hline & $13.9 \%$ & $17.0 \%$ & $49.2 \%$ & $27.6 \%$ & $3.8 \%$ & $111.4 \%$ \\
\hline Pith (MBI) & $14.0 \%$ & $19.7 \%$ & $20.4 \%$ & & & \\
\hline CLM (ASI) & $19.7 \%$ & $23.7 \%$ & $21.2 \%$ & $6.0 \%$ & $5.0 \%$ & $75.7 \%$ \\
\hline & $20.9 \%$ & $22.4 \%$ & $23.8 \%$ & $5.8 \%$ & $4.9 \%$ & $77.8 \%$ \\
\hline CLM (ASI) & $23.3 \%$ & $28.5 \%$ & $21.5 \%$ & $13.4 \%$ & $5.3 \%$ & $92.0 \%$ \\
\hline CLM (MBI) & $24.5 \%$ & $31.9 \%$ & $20.8 \%$ & & & $77.2 \%$ \\
\hline Bagasse (ASI) & $22.8 \%$ & $34.5 \%$ & $20.1 \%$ & $8.8 \%$ & $3.2 \%$ & $89.4 \%$ \\
\hline Bagasse (MBI) & $19.9 \%$ & $34.6 \%$ & & & & \\
\hline
\end{tabular}

*These results are from work conducted at Audubon Sugar Institute and were published in The Sugar Bulletin, vol. 82, July 2004.

This table shows that for the pith samples, the mass balances exceeded $100 \%$ and both the ash and lignin contents were rather high. In bagasse, acid insoluble ash can be high and this is counted twice, both in the lignin and ash fractions. Ashing the lignin fraction is 
required to correct this. The mass balances for CLM are lower than the literature values, but consistent with MBI. Comparisons with the literature can only be approximate, however, because biomass composition is known to vary with harvesting time and geographic location.

\section{Fractionation of AFEX-treated bagasse pith and CLM solids}

Pith and Cane Leaf Matter (CLM) pretreated with the AFEX process (pith and CLM) were received from MBI for further pretreatment with water and sodium hydroxide.

Aqueous extracts were found to contain primarily lignin and small quantities of hemicellulose. There was a higher weight percent loss of the biomass when it was treated with alkali $(25 \%)$ as compared to pretreatment with water $(48 \%)$. These extractions were done at $100{ }^{\circ} \mathrm{C}$.

Water extractions were performed at 120 and $140{ }^{\circ} \mathrm{C}$ resulted in an enhanced glucan conversion with saccharification in the range of $67-88 \%$ (72 hour glucan yield, $120{ }^{\circ} \mathrm{C}$ ). The range of saccharification yield for AFEX-only treated material was 52-70\%. To consolidate results, the water and sodium hydroxide extractions were repeated at 120 and $140{ }^{\circ} \mathrm{C}$. The goal of the second extraction was to remove lignin and hemicellulose, producing a biomass with higher cellulose content. Removal of saccharification and fermentation inhibitors occurs during the second pretreatment. Table 14 shows the quantity of lignin solubilized by the hydrothermal treatment. There was greater removal of both lignin and ash at $120^{\circ} \mathrm{C}$.

The composition of the hydrolysate from water treatment is Table 15. Most of the sugars extracted are oligomers with xylose oligomers being dominant. All of the arabinose is recovered..

Lignin removal after one hour treatment with $1 \% \mathrm{NaOH}$ for AFEX treated samples is shown in Table 16. As was found in the previous year, more Klason lignin and acid soluble lignin was removed compared to the water extraction. The composition of the base treated hydrolysate is given in Table 16. Most of the sugars extracted are xylose oligomers (Table 17).

Table 14: Quantity of solubilized lignin after post-AFEX water extraction in the hydrolysates expressed as $\mathrm{g} / \mathbf{1 0 0} \mathrm{g}$ dry substrate.

\begin{tabular}{|c|c|c|c|}
\hline & 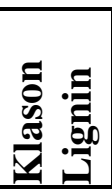 & 을 & 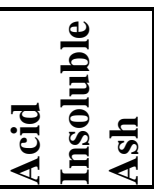 \\
\hline $\begin{array}{l}\text { Pith, } \\
120^{\circ} \mathrm{C}\end{array}$ & 7.9 & 4.3 & 1.8 \\
\hline $\begin{array}{l}\text { Pith, } \\
140^{\circ} \mathrm{C}\end{array}$ & 3.9 & 3.6 & 1.9 \\
\hline
\end{tabular}




\begin{tabular}{|l|l|l|l|}
\hline $\begin{array}{l}\mathbf{C L M} \\
\mathbf{1 2 0}^{\circ} \mathbf{C}\end{array}$ & 6.8 & 4.6 & 1.5 \\
\hline $\begin{array}{l}\mathbf{C L M} \\
\mathbf{1 4 0}^{\circ} \mathbf{C}\end{array}$ & 5.9 & 4.4 & 1.1 \\
\hline
\end{tabular}

Table 15: Quantity of solubilized oligomers after post-AFEX water extraction in the hydrolysates expressed as g/100 g dry substrate.

\begin{tabular}{|c|c|c|c|}
\hline \multicolumn{4}{|c|}{ Oligomer } \\
\hline & $\stackrel{\mathscr{U}}{\mathscr{U}}$ & $\frac{\ddot{n}}{\vec{x}}$ & 总 \\
\hline $\begin{array}{l}\text { Pith, } \\
120^{\circ} \mathrm{C}\end{array}$ & 2.7 & 6.0 & 1.3 \\
\hline $\begin{array}{l}\text { Pith, } \\
140^{\circ} \mathrm{C}\end{array}$ & 2.2 & 5.6 & 1.3 \\
\hline $\begin{array}{l}\text { CLM } \\
120^{\circ} \mathrm{C} \\
\end{array}$ & 1.9 & 8.7 & 2.1 \\
\hline $\begin{array}{l}\text { CLM } \\
140^{\circ} \mathrm{C}\end{array}$ & 0.6 & 7.0 & 2.3 \\
\hline
\end{tabular}

Table 16: Quantity of solubilized lignin in the hydrolysates from post-AFEX NaOH extraction expressed as $\mathrm{g} / \mathbf{1 0 0} \mathrm{g}$ dry substrate.

\begin{tabular}{|c|c|c|c|}
\hline & 司. & 冚 & 总 \\
\hline $\begin{array}{l}\text { Pith, } \\
120^{\circ} \mathrm{C}\end{array}$ & 10.8 & 6.3 & 2.4 \\
\hline $\begin{array}{l}\text { Pith, } \\
140^{\circ} \mathrm{C}\end{array}$ & 8.5 & 7.1 & 1.7 \\
\hline $\begin{array}{l}\text { CLM } \\
120^{\circ} \mathrm{C}\end{array}$ & 8.9 & 7.7 & 1.5 \\
\hline $\begin{array}{l}\text { CLM } \\
140^{\circ} \mathrm{C}\end{array}$ & 8.4 & 8.6 & 1.1 \\
\hline
\end{tabular}


Table 17: Quantity of solubilized oligomers after post-AFEX NaOH extraction in the hydrolysates expressed as $\mathrm{g} / \mathbf{1 0 0} \mathrm{g}$ dry substrate.

\begin{tabular}{|c|c|c|c|}
\hline \multicolumn{4}{|c|}{ Oligomer } \\
\hline & 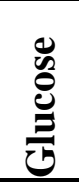 & $\frac{\ddot{D}}{\not{\lambda}}$ & 。 \\
\hline $\begin{array}{l}\text { Pith, } \\
120^{\circ} \mathrm{C}\end{array}$ & 1.2 & 6.0 & 2.6 \\
\hline $\begin{array}{l}\text { Pith, } \\
140^{\circ} \mathrm{C}\end{array}$ & 5.7 & 11.1 & 2.0 \\
\hline $\begin{array}{l}\text { CLM } \\
120^{\circ} \mathrm{C}\end{array}$ & 1.0 & 8.9 & 1.8 \\
\hline $\begin{array}{l}\text { CLM } \\
140^{\circ} \mathrm{C}\end{array}$ & 1.6 & 13.2 & 3.3 \\
\hline
\end{tabular}

The $\%$ glucan in the extracted samples was higher than the $\%$ glucan in the untreated samples after a second extraction. The extraction processes removed some of the hemicellulose and the extractives from the biomass which results in higher glucan content and also makes the biomass more digestible. As expected, the extracted samples gave high glucose yields and for $\mathrm{NaOH}$ extracted samples, all the available glucan was converted to glucose.

Conclusion: An alkali pretreatment increased the saccharification of AFEX-treated biomass.

\section{Post-AFEX Extractions}

The weight loss depended on the solvent used; water gave least weight loss followed by acid, followed by alkaline extraction. An analysis was performed of the AFEX extracts. These extracts were concentrated and spray-dried to produce a powder. The carbohydrate and ash contents of the powders are given in Figure 5. 


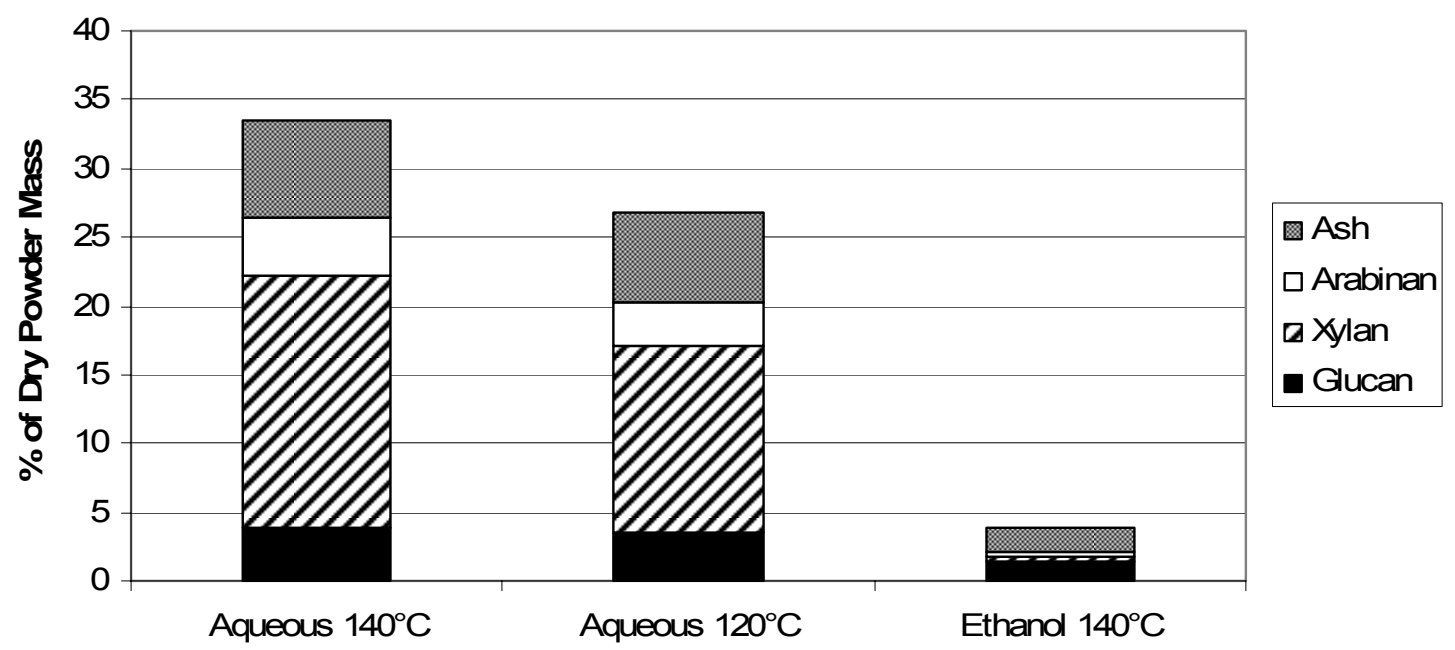

Figure 5: Carbohydrate and ash content of powders produced by spray drying from the liquid obtained from post AFEX extractions of CLM and bagasse.

This graph shows that the extract is composed mostly of a non-carbohydrate and we expect it to be mostly lignin. Based on this consideration, the estimate of lignin purity is about $95 \%$ in the ethanol extract to close to $75 \%$ in the aqueous extract produced at $120^{\circ} \mathrm{C}$. Aqueous extraction removes significantly more sugars than ethanol. Also, as expected, most of the sugars removed are pentoses from the hemicellulose and only a small amount of glucan is removed. This glucan is likely to be amorphous which is extractable whereas crystalline cellulose requires more severe conditions to dissolve. For the ethanol extracted sample, none of the hemicellulose was removed. This is because ethanol does not act as a catalyst for hydrolysis the way that water does. Furthermore, sugar solubility is very low in ethanol. The aqueous samples also contained more ash than the ethanol extracts.

Ethanol

The compositions of the fibers from the ethanol extractions are shown in Table 18. The weight loss is the quotient of the dry fiber mass after pretreatment divided by the original dry fiber mass. Most of the glucan in biomass is in the form of crystalline cellulose, and it is assumed that none of it is removed by pretreatment. Thus during pretreatment, other components like hemicellulose, lignin, ash, and extractives are partially removed, creating a substrate with a slightly higher cellulose content on a dry weight basis.

Table 2 shows the analysis for the fibers from post AFEX ethanol extraction at $120^{\circ} \mathrm{C}$ and $140^{\circ} \mathrm{C}$. Samples that were treated by AFEX at different conditions were combined in order to have a large enough substrate for extraction in the Parr apparatus. The Sample ID's are the ID's from AFEX. In order to evaluate this procedure, Table 3 also includes the weight losses and the glucan contents based on those weight losses. 
Table 18: Composition of fibers after AFEX pretreatment and ethanol extraction. Weight per cent ( $\mathrm{g} / \mathbf{1 0 0} \mathrm{g}$ dry matter).

\begin{tabular}{|c|c|c|c|c|c|c|c|c|}
\hline Treatment & $\begin{array}{c}\text { Sample } \\
\text { ID }\end{array}$ & $\begin{array}{l}\text { Wt. } \\
\text { loss }\end{array}$ & $\begin{array}{l}\text { Hemi- } \\
\text { cellulos } \\
\text { e }\end{array}$ & $\begin{array}{l}\text { Cellulos } \\
\mathbf{e}\end{array}$ & $\begin{array}{c}\text { Cellulose } \\
\text { (based } \\
\text { on wt. } \\
\text { loss) } \\
\end{array}$ & Lignin & Ash & Total \\
\hline $\begin{array}{l}\text { Untreated } \\
\text { CLM }\end{array}$ & & & $23.3 \%$ & $28.5 \%$ & & $22 \%$ & $\begin{array}{l}13 \\
\%\end{array}$ & $87 \%$ \\
\hline $\begin{array}{l}\text { Untreated } \\
\text { Bagasse }\end{array}$ & & & $22.8 \%$ & $34.5 \%$ & & $20 \%$ & $9 \%$ & $86 \%$ \\
\hline \multirow{2}{*}{$\begin{array}{l}\text { AFEX, } \\
\text { Bagasse, } \\
120^{\circ} \mathrm{C}\end{array}$} & \multirow{2}{*}{$\begin{array}{l}99 \mathrm{~A}, \\
99 \mathrm{~B}, \\
100 \mathrm{~A}, \\
100 \mathrm{~B}\end{array}$} & $\begin{array}{c}12.70 \\
\%\end{array}$ & $36 \%$ & $49 \%$ & $40 \%$ & $25 \%$ & $\begin{array}{l}13 \\
\%\end{array}$ & $123 \%$ \\
\hline & & & $27 \%$ & $48 \%$ & & $24 \%$ & $\begin{array}{l}13 \\
\%\end{array}$ & $112 \%$ \\
\hline \multirow{2}{*}{$\begin{array}{l}\mathrm{AFEX}, \mathrm{CLM}, \\
120^{\circ} \mathrm{C}\end{array}$} & \multirow{2}{*}{$\begin{array}{l}83 / 85 / \\
86\end{array}$} & $8.50 \%$ & $29 \%$ & $29 \%$ & $31 \%$ & $32 \%$ & $\begin{array}{l}11 \\
\%\end{array}$ & $101 \%$ \\
\hline & & & $33 \%$ & $36 \%$ & & $27 \%$ & $\begin{array}{l}11 \\
\%\end{array}$ & $107 \%$ \\
\hline \multirow{2}{*}{$\begin{array}{l}\text { AFEX, CLM, } \\
120^{\circ} \mathrm{C}^{*}\end{array}$} & & $4.60 \%$ & $19 \%$ & $10 \%$ & $27 \%$ & $46 \%$ & $7 \%$ & $82 \%$ \\
\hline & & & $30 \%$ & $15 \%$ & & $45 \%$ & $7 \%$ & $96 \%$ \\
\hline \multirow{2}{*}{$\begin{array}{l}\text { AFEX, } \\
\text { Bagasse, } \\
140^{\circ} \mathrm{C}\end{array}$} & \multirow{2}{*}{$\begin{array}{l}91 \mathrm{~A}, \\
91 \mathrm{~B}, \\
94 \mathrm{~B}, \\
98 \mathrm{~B}\end{array}$} & $\begin{array}{c}10.70 \\
\%\end{array}$ & $40 \%$ & $39 \%$ & $39 \%$ & $22 \%$ & $\begin{array}{l}14 \\
\%\end{array}$ & $114 \%$ \\
\hline & & & $52 \%$ & $50 \%$ & & $22 \%$ & $\begin{array}{l}22 \\
\%\end{array}$ & $114 \%$ \\
\hline \multirow{2}{*}{$\begin{array}{l}\text { AFEX CLM, } \\
140^{\circ} \mathrm{C}\end{array}$} & \multirow{2}{*}{$\begin{array}{l}64 \mathrm{~A}, \\
65 \mathrm{~B}, \\
67 \mathrm{~A}, \\
68 \mathrm{~A}\end{array}$} & $7.90 \%$ & $22 \%$ & $28 \%$ & $31 \%$ & $27 \%$ & $\begin{array}{l}13 \\
\%\end{array}$ & $89 \%$ \\
\hline & & & $29 \%$ & $29 \%$ & & $25 \%$ & $\begin{array}{l}13 \\
\%\end{array}$ & $96 \%$ \\
\hline \multirow{2}{*}{$\begin{array}{l}\text { AFEX, CLM, } \\
140^{\circ} \mathrm{C}\end{array}$} & \multirow{2}{*}{$\begin{array}{l}91 \mathrm{~A}, \\
91 \mathrm{~B}, \\
94 \mathrm{~B}, \\
98 \mathrm{~B}\end{array}$} & $9.90 \%$ & $46 \%$ & $33 \%$ & $32 \%$ & $26 \%$ & $\begin{array}{l}14 \\
\%\end{array}$ & $119 \%$ \\
\hline & & & $42 \%$ & $32 \%$ & & $26 \%$ & $\begin{array}{l}14 \\
\%\end{array}$ & $113 \%$ \\
\hline \multirow{2}{*}{$\begin{array}{l}\mathrm{AFEX}, \mathrm{CLM}, \\
140^{\circ} \mathrm{C}\end{array}$} & \multirow{2}{*}{$\begin{array}{l}83 \mathrm{~B}, \\
86 \mathrm{~B}, \\
87 \mathrm{~A}, \\
88 \mathrm{~A}\end{array}$} & $\begin{array}{c}14.70 \\
\%\end{array}$ & $43 \%$ & $33 \%$ & $33 \%$ & $25 \%$ & $\begin{array}{l}13 \\
\%\end{array}$ & $114 \%$ \\
\hline & & & $33 \%$ & $25 \%$ & & $25 \%$ & $\begin{array}{l}13 \\
\%\end{array}$ & $97 \%$ \\
\hline
\end{tabular}

*Because of the low glucan content measured in this analysis, this sample was repeated, this time with proper grinding, screening, and removal of extractives. The composition was then $31-36 \%$ hemicellulose, $29-35 \%$ glucan, and $24-25 \%$ lignin.

The main carbohydrate in the extracts from ethanol was glucose whereas in the aqueous extract, it is xylose. At higher temperatures, amorphous glucose is removed faster but the xylan removal may stay the same. 
Water

For the water extracts, there is an even greater variability, however, the lignin content is increased compared to untreated bagasse and CLM, and the hemicellulose content is overall reduced (Table 19).

Table 19: Composition of fibers after AFEX pretreatment and water extraction. Weight per cent (g / 100 g dry matter).

\begin{tabular}{|c|c|c|c|c|c|c|c|c|}
\hline $\begin{array}{c}\text { Treatme } \\
\text { nt }\end{array}$ & $\begin{array}{c}\text { Sample } \\
\text { ID }\end{array}$ & $\begin{array}{l}\text { Wt. } \\
\text { loss }\end{array}$ & $\begin{array}{c}\text { Hemi- } \\
\text { cellulos } \\
\text { e }\end{array}$ & Cellulose & $\begin{array}{c}\text { Cellulose } \\
\text { (based on } \\
\text { wt. loss) } \\
\end{array}$ & $\begin{array}{c}\text { Ligni } \\
\mathbf{n}\end{array}$ & Ash & Total \\
\hline $\begin{array}{l}\text { Untreated } \\
\text { CLM }\end{array}$ & & & $23.3 \%$ & $28.5 \%$ & & $22 \%$ & $13 \%$ & $87 \%$ \\
\hline $\begin{array}{l}\text { Untreated } \\
\text { Bagasse } \\
\end{array}$ & & & $22.8 \%$ & $34.5 \%$ & & $20 \%$ & $9 \%$ & $86 \%$ \\
\hline \multirow{2}{*}{$\begin{array}{l}\text { No } \\
\text { AFEX, } \\
\text { CLM, } \\
120^{\circ} \mathrm{C}\end{array}$} & & $6.20 \%$ & $25 \%$ & $31 \%$ & $30 \%$ & $21 \%$ & $5 \%$ & $83 \%$ \\
\hline & & & $25 \%$ & $30 \%$ & & $25 \%$ & $30 \%$ & $109 \%$ \\
\hline \multirow{2}{*}{$\begin{array}{l}\text { AFEX, } \\
\text { CLM, } \\
120^{\circ} \mathrm{C}\end{array}$} & \multirow{2}{*}{$\begin{array}{l}64 \mathrm{~A}, \\
65 \mathrm{~B}, \\
66 \mathrm{~A}, \\
66 \mathrm{C}\end{array}$} & $\begin{array}{c}37.20 \\
\%\end{array}$ & $20 \%$ & $32 \%$ & $45 \%$ & $24 \%$ & $9 \%$ & $85 \%$ \\
\hline & & & $21 \%$ & $32 \%$ & & $26 \%$ & $9 \%$ & $88 \%$ \\
\hline \multirow{2}{*}{$\begin{array}{l}\text { AFEX, } \\
\text { CLM, } \\
120^{\circ} \mathrm{C}\end{array}$} & \multirow{2}{*}{$\begin{array}{l}86 \mathrm{~A}, \\
86 \mathrm{~B}, \\
83 \mathrm{~B}, \\
85 \mathrm{~B}\end{array}$} & $\begin{array}{c}30.00 \\
\%\end{array}$ & $16 \%$ & $25 \%$ & $41 \%$ & $43 \%$ & $12 \%$ & $96 \%$ \\
\hline & & & $16 \%$ & $26 \%$ & & $40 \%$ & $12 \%$ & $94 \%$ \\
\hline \multirow{2}{*}{$\begin{array}{l}\text { AFEX, } \\
\text { Baggasse, } \\
120^{\circ} \mathrm{C}\end{array}$} & \multirow{2}{*}{$\begin{array}{l}99 \mathrm{~A}, \\
99 \mathrm{~B}, \\
100 \mathrm{~A}, \\
100 \mathrm{~B}\end{array}$} & $\begin{array}{c}22.20 \\
\%\end{array}$ & $22 \%$ & $38 \%$ & $44 \%$ & $28 \%$ & $11 \%$ & $98 \%$ \\
\hline & & & $23 \%$ & $32 \%$ & & $32 \%$ & $11 \%$ & $98 \%$ \\
\hline \multirow{2}{*}{$\begin{array}{l}\text { AFEX } \\
\text { CLM, } \\
140^{\circ} \mathrm{C}\end{array}$} & \multirow{2}{*}{$\begin{array}{l}67 \mathrm{~A}, \\
68 \mathrm{~A}\end{array}$} & $\begin{array}{c}23.70 \\
\%\end{array}$ & $26 \%$ & $8 \%$ & $37 \%$ & $41 \%$ & $13 \%$ & $88 \%$ \\
\hline & & & $29 \%$ & $29 \%$ & & $38 \%$ & $10 \%$ & $106 \%$ \\
\hline \multirow{2}{*}{$\begin{array}{l}\text { AFEX, } \\
\text { Bagasse, } \\
140^{\circ} \mathrm{C}\end{array}$} & \multirow{2}{*}{$\begin{array}{l}90 \mathrm{~A}, \\
90 \mathrm{~B}\end{array}$} & $\begin{array}{c}\text { Not } \\
\text { known }\end{array}$ & $23 \%$ & $35 \%$ & Not known & $37 \%$ & $15 \%$ & $110 \%$ \\
\hline & & & $23 \%$ & $34 \%$ & & $38 \%$ & $15 \%$ & $109 \%$ \\
\hline \multirow{2}{*}{$\begin{array}{l}\text { AFEX, } \\
\text { Bagasse, } \\
140^{\circ} \mathrm{C}\end{array}$} & \multirow{2}{*}{$\begin{array}{l}91 \mathrm{~B}, \\
93 \mathrm{~B}\end{array}$} & $\begin{array}{c}25.70 \\
\%\end{array}$ & $34 \%$ & $47 \%$ & $46 \%$ & $47 \%$ & $12 \%$ & $140 \%$ \\
\hline & & & $21 \%$ & $34 \%$ & & $41 \%$ & $12 \%$ & $108 \%$ \\
\hline \multirow{2}{*}{$\begin{array}{l}\text { AFEX, } \\
\text { Bagasse, } \\
140^{\circ} \mathrm{C}\end{array}$} & \multirow{2}{*}{$\begin{array}{l}91 \mathrm{~A} \\
98 \mathrm{~A} \\
98 \mathrm{~B}\end{array}$} & $\begin{array}{c}27.40 \\
\%\end{array}$ & $20 \%$ & $39 \%$ & $48 \%$ & $30 \%$ & $6 \%$ & $95 \%$ \\
\hline & & & $19 \%$ & $31 \%$ & & $40 \%$ & $13 \%$ & $103 \%$ \\
\hline
\end{tabular}

Enzymatic Hydrolysis 
Table 20 shows our results for the enzymatic digestibility at 72 hours for $15 \mathrm{FPU} / \mathrm{g}$ glucan of Spezyme ${ }^{\circledR}$ and $42 \mathrm{CBU} / \mathrm{g}$ glucan of Novozyme ${ }^{\circledR}$. Many more tests were performed, however a large number of samples showed contamination in that a higher digestibility was measured at 24 or 48 hours than 72 hours. In those instances, microbial infection occurred in the sample flask and consumed some of the glucose. We are taking steps to avoid this problem by autoclaving flasks before experiments and limiting exposure to air during sampling. The samples given in Table 3 did not suffer from this problem.

Table 20: Enzyme Hydrolysis of fibers after AFEX pretreatment and extraction.

\begin{tabular}{|c|c|c|c|c|c|}
\hline 莺 & 慁 & 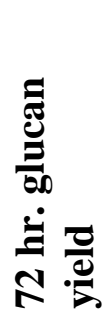 &  & 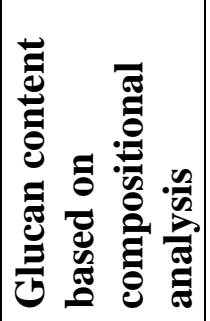 & 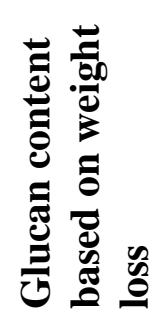 \\
\hline \multirow{2}{*}{$\begin{array}{l}\text { AFEX, CLM, } \\
100 \% \mathrm{EtOH}, \\
140^{\circ} \mathrm{C}, 1 \mathrm{hr} . \\
\end{array}$} & \multirow{2}{*}{$\begin{array}{l}83 \mathrm{~B}, 86 \mathrm{~B}, \\
87 \mathrm{~A}, \text { and } \\
88 \mathrm{~A}\end{array}$} & $9 \%$ & $75 \%-84 \%$ & $10 \%$ & $27 \%$ \\
\hline & & $16 \%$ & & $15 \%$ & \\
\hline \multirow{2}{*}{$\begin{array}{l}\text { AFEX, CLM, } \\
100 \% \mathrm{EtOH}, \\
140^{\circ} \mathrm{C}, 1 \mathrm{hr} .\end{array}$} & \multirow{2}{*}{$\begin{array}{l}83 \mathrm{~B}, 85 \mathrm{~B} \\
86 \mathrm{~A}, 86 \mathrm{~B}\end{array}$} & $15 \%$ & $77 \%-84 \%$ & $29 \%$ & $31 \%$ \\
\hline & & $14 \%$ & & $36 \%$ & \\
\hline \multirow{2}{*}{$\begin{array}{l}\text { AFEX, CLM, } \\
100 \% \mathrm{EtOH}, \\
140^{\circ} \mathrm{C}, 1 \mathrm{hr} .\end{array}$} & \multirow{2}{*}{$\begin{array}{l}91 \mathrm{~A}, 91 \mathrm{~B}, \\
94 \mathrm{~B}, 98 \mathrm{~B}\end{array}$} & $10 \%$ & $69 \%-75 \%$ & $50 \%$ & $39 \%$ \\
\hline & & $9 \%$ & & $39 \%$ & \\
\hline \multirow{2}{*}{$\begin{array}{l}\text { AFEX, CLM, } \\
\text { EtOH, } 140^{\circ} \mathrm{C}, 1 \\
\text { hr. }\end{array}$} & \multirow{2}{*}{$\begin{array}{l}64 \mathrm{~A}, 65 \mathrm{~A} \\
67 \mathrm{~A}, 68 \mathrm{~A}\end{array}$} & $31 \%$ & $44 \%-49 \%$ & $28 \%$ & $31 \%$ \\
\hline & & $26 \%$ & & $29 \%$ & \\
\hline \multirow{2}{*}{$\begin{array}{l}\text { No AFEX, CLM, } \\
\text { Aqueous, } 120^{\circ} \mathrm{C}, \\
1 \text { hr.* }\end{array}$} & & $38 \%$ & $13 \%$ & $31 \%$ & $30 \%$ \\
\hline & & $42 \%$ & & $30 \%$ & \\
\hline \multirow{2}{*}{$\begin{array}{l}\text { AFEX, CLM, } \\
\text { Aqueous, } 120^{\circ} \mathrm{C}, \\
1 \mathrm{hr} \text {. }\end{array}$} & \multirow{2}{*}{$\begin{array}{l}64 \mathrm{~A}, 65 \mathrm{~B} \\
66 \mathrm{~A}, 66 \mathrm{C}\end{array}$} & $68 \%$ & $48 \%-62 \%$ & $32 \%$ & $45 \%$ \\
\hline & & $68 \%$ & & $32 \%$ & \\
\hline \multirow{2}{*}{$\begin{array}{l}\text { AFEX CLM, } \\
\text { Aqueous, } 120^{\circ} \mathrm{C}, \\
1 \mathrm{hr} \text {. }\end{array}$} & \multirow{2}{*}{$\begin{array}{l}86 \mathrm{~A}, 86 \mathrm{~B} \\
83 \mathrm{~B}, 85 \mathrm{~B}\end{array}$} & $88 \%$ & $75 \%-84 \%$ & $25 \%$ & $41 \%$ \\
\hline & & - & & $26 \%$ & \\
\hline \multirow{2}{*}{$\begin{array}{l}\text { AFEX, Bagasse, } \\
\text { Aqueous, } 120^{\circ} \mathrm{C}, \\
1 \mathrm{hr} \text {. }\end{array}$} & \multirow{2}{*}{$\begin{array}{l}99 \mathrm{~A}, 99 \mathrm{~B}, \\
100 \mathrm{~A}, \\
100 \mathrm{~B}\end{array}$} & $84 \%$ & $52 \%-70 \%$ & $38 \%$ & $44 \%$ \\
\hline & & $67 \%$ & & $32 \%$ & \\
\hline
\end{tabular}

*This sample was not AFEX treated before extraction and the yield of raw CLM is $13 \%$.

Table 20 presents the glucose yields of post AFEX extracted samples and compares it to the yields for just AFEX pretreated samples. However, because the material used for the 
extractions was a composite of materials treated at different AFEX conditions, a range is presented of the lowest and highest digestibility of the samples collected in that lot. The ethanol extracted samples consistently exhibited a lower yield than the non-extracted samples. The reason for this is unknown, but we believe that ethanol may have collapsed the pores of the biomass structure, making it less accessible to cellulose enzymes. It is believed that such pore structures are maintained, in part, through the action of bound water. Ethanol has a drying effect. For the samples that were extracted with water at $120^{\circ} \mathrm{C}$, the first was not AFEX treated at all, and it had a digestibility of $38-42 \%$, which was less than all the AFEX digestibility but significantly higher than the untreated CLM $(13 \%)$. The 64A - 66C and 86A-85B samples both clearly had a higher yield after aqueous extraction than with just AFEX, and the improvements were between $4-20 \%$ and $4-13 \%$. These higher digestibilities would give an ethanol yield increase of 0.4 to 1.75 gallons per dry ton CLM. For the last sample, a digestibility of $67-88 \%$ was measured. This is a large range, but the range from only AFEX treatment was 52\%-70\%. These results indicate that an aqueous post AFEX extraction is promising. Furthermore, enzyme hydrolysis requires an aqueous slurry with solid concentration of about $10 \%$ or less. The substrate after AFEX is relatively dry after ammonia recovery, and will have to be contacted with water before saccharification and fermentation. The extract is composed mostly of lignin and some of the hemicellulose sugars. If market can be found for the lignin or pentose sugars, aqueous extraction provides a ready source.

Washing

A recent publication from Michigan State University (MSU) (Shishir et al., 2007) indicated that washing AFEX-treated corn stover improved the glucan conversion of the biomass in high solid loading hydrolysis. Therefore, in an effort to improve the enzymatic hydrolysis and ultimately the fermentation yield, the AFEX-treated bagasse was washed with water. The solid and liquid portions were separated by filtration. The glucan and xylan content of both washed and unwashed AFEX-treated biomass were analyzed. Glucan and xylan contents of the washed sample were $39.4 \%$ and $18.8 \%$ respectively, and the unwashed sample contained $35.8 \%$ glucan and $16.3 \%$ xylan. To demonstrate the effect of washing, enzyme hydrolyses at different solid loadings were conducted with both washed and unwashed samples. The results are presented in Table 21 . The hydrolysis yields from washed samples were unexpectedly lower or equal to the hydrolysis results of unwashed samples

Table 21. 72-hr Hydrolysis Results of Washed and Unwashed AFEX-treated Bagasse Samples with 15 FPU of Spezyme Cp and 42 CBU of Novo 188 per Gram of Cellulose. (Yields are based on sugar content of the biomass.)

\begin{tabular}{|l|c|}
\hline \multicolumn{1}{|l|}{} & Glucose yield \\
\hline 1\% glucan loading \\
\hline Unwashed sample & $76 \% \pm 2$ \\
\hline Washed sample & $72 \% \pm 0$ \\
\hline 2\% glucan loading \\
\hline Unwashed sample & $75 \% \pm 2$ \\
\hline Washed sample & $74 \% \pm 0$ \\
\hline
\end{tabular}




\begin{tabular}{|l|l|}
\hline \multicolumn{2}{|l|}{ 3\% glucan loading } \\
\hline Unwashed sample & $70 \% \pm 1$ \\
\hline Washed sample & $70 \% \pm 2$ \\
\hline
\end{tabular}

\section{Materials and methods (Task 2)}

Alkaline and water extraction. For each test, $33.6 \mathrm{~g}$ of AFEX treated pith at $74.5 \%$ solids (i. e. $25 \mathrm{~g}$ of bone dry pith) was placed in a 5-gal Parr reactor containing $500 \mathrm{ml}$ of deionized water. The same test is done using $31.7 \mathrm{~g}$ of AFEX-treated CLM, at $78.8 \%$ solids (i. e. $25 \mathrm{~g}$ of bone dry CLM). The vessel was stirred by a spiral agitator and constantly heated. The approximate heat-up time to $120^{\circ} \mathrm{C}$ was $19 \mathrm{~min}$ and $21 \mathrm{~min}$ to reach $140{ }^{\circ} \mathrm{C}$. Once the target temperature was reached, it was maintained for an hour. After one hour, the heating jacket was shut off and the vessel cooled to $65^{\circ} \mathrm{C}$ within $3-4$ hr. The Parr reactor was fitted with a frit to filter the solution. An adapter was added to the bottom port and attached with tygon tubing to the side arm of a filter flask. The top of the flask was attached to vacuum. The liquid was collected in the vacuum flask. The fiber was recovered from the reactor. Both liquid and solid were refrigerated.

Following AFEX treatment, bagasse pith and CLM solids were treated with a base or other solvent to separate cellulose and hemicellulose. The residual solid, which is rich in cellulose, was recovered by filtration. Ethanol was added to the supernatant to precipitate the extracted hemicellulose, which can be recovered by filtration. Other ways such as membrane filtration or crystallization were considered for recovering solubilized noncellulose components.

The AFEX-treated bagasse pith and CLM samples were extracted with water and $\mathrm{NaOH}$ at two different temperatures $\left(120\right.$ and $\left.140^{\circ} \mathrm{C}\right)$ by ASI. The generated solids were sent to us for composition analysis and enzyme hydrolysis. The samples received were very wet. A portion of each sample was used for composition analysis and the rest for enzyme hydrolysis. The samples for the composition analysis should be dry; therefore, for the water extracted samples, the liquid was squeezed out using a Buchner funnel and vacuum and the samples were dried at $45^{\circ} \mathrm{C}$. The rest of the samples were used for enzyme hydrolysis as received. The moisture content of the samples was taken into account for the hydrolysis.

For $\mathrm{NaOH}$ extracted samples, the liquid was squeezed out from the whole sample and the solid portion was washed several times with water to bring the $\mathrm{pH}$ of the wash close to 7 . A portion of the samples were dried for composition analysis and the rest were used for enzyme hydrolysis.

Bagasse samples pretreated with different concentrations of $\mathrm{NaOH}$ and $\mathrm{NH}_{4} \mathrm{OH}$ $(1 \%, 2 \%, 4 \%, 6 \%)$ prior to treatment were AFEX-treated at $100^{\circ} \mathrm{C}, 40 \%$ moisture content and 1:1 ammonia loading for $30 \mathrm{~min}$. In some cases, the duplicate results of this series of 
experiments showed relatively large deviations; therefore, it is not possible to draw firm conclusions.

Several bagasse samples treated with different combinations of peroxide/hypochlorite solution (referred to as Ox-B) were received from LSU. These samples were AFEXtreated under two different sets of AFEX conditions $\left(100^{\circ} \mathrm{C}, 40 \% \mathrm{MC}\right.$ and two ammonia loadings: 2:1 and 1:1 for 30 minutes). All of the Ox-B-AFEX-treated bagasse samples were hydrolyzed and the obtained data showed that no significant improvements were observed on the glucose yield.

Unground CLM was AFEX-treated at $100^{\circ} \mathrm{C}, 40 \%$ moisture content and 2:1 ammonia loading for $30 \mathrm{~min}$. Enzyme hydrolysis of this sample gave glucose and xylose yields that were not significantly different from those obtained from ground CLM AFEXtreated under the same conditions. These data indicate that grinding of CLM offers no direct benefit to the efficacy of AFEX pretreatment.

Several batches of AFEX-treated bagasse $\left(100^{\circ} \mathrm{C}, 40 \% \mathrm{MC}, 2: 1\right.$, and $\left.30 \mathrm{~min}\right)$ were produced and combined for ethanol fermentation. The fermentation was performed with two solid loadings, 4\% and 8\%, with recombinant Zymomonas mobilis 37821(pZB5) using separate hydrolysis and fermentation (SHF). Even though these hydrolyses were performed with much higher solid loading (4 and 8\%) compared to regular hydrolysis loading (in a small shake flask $\sim 2 \%$ ), the hydrolysis yields were higher and we were able to ferment all the produced glucose and xylose to ethanol.

Enzyme hydrolyses with 15, 20 and 30 FPU of Spezyme Cp/g glucan were performed on both AFEX-treated bagasse and CLM. AFEX-treated CLM and bagasse were hydrolyzed with a combination of cellulase (Spezyme $\mathrm{Cp}$ ) and several xylanases. Using the combined enzyme mixture resulted in an increase in both glucose and xylose yields. 
Two cellulase-free xylanases were examined for selective hydrolysis of hemicellulose of AFEXtreated CLM and bagasse. The best case for AFEX-treated CLM gave a 52\% yield of xylose after 72 hours of hydrolysis and 60\% after 168 hours, while leaving more than $93 \%$ cellulose in the biomass. For AFEX-treated bagasse, the best case gave a 53\% xylose yield and 5\% glucose yield after 72 hours of hydrolysis and $60 \%$ and $6 \%$ yields for xylose and glucose respectively, after 168 hours of hydrolysis.

Composition (glucan, xylan, galactan, arabinan, lignin and ash) of the biomass was determined by following the National Renewable Energy Laboratory (NREL) procedure, (NREL LAP-002). NREL procedures are available at:

http://www.ott.doe.gov/biofuels/analytical_methods.html.

Extractive content was measured according to NREL procedure LAP-010.

Enzymatic hydrolysis was carried out by following the NREL LAP-009 procedure. Hydrolysate samples were analyzed for glucose, xylose, cellobiose, arabinose, mannose and galactose content by HPLC, using an Aminex-HPX-87P column (Bio-Rad). All hydrolyses were performed in duplicate and the data are presented as the average of the duplicates.

\section{Task 3}

Sugar cane bagasse is a lignocellulose biomass produced as a byproduct from sugar extraction in vast amounts that will continue to increase in light of increased worldwide sugar production. Considerable amounts of bagasse are currently used as a combustible energy source, for paper pulp production or animal feed. However the relatively high carbohydrate and low lignin content make bagasse an attractive substrate for ethanol production. Approximately 24 and $38 \%$ (dry weight) of bagasse consists of hemicellulose and cellulose respectively, and bioconversion of both fractions to ethanol must be considered for a viable process. Pretreatment of bagasse is necessary to reduce the recalcitrance to enzymatic hydrolysis. Previous studies have reported the pretreatment of sugar cane bagasse with either physical or chemical methods such as acid (Martin et al., 2002), steam (Kaar et al., 1998) or alkali (Fox et al., 1987; Holtzapple et al., 1991). Chemical pretreatments generally remove the hemicellulose or lignin fraction thereby promoting cellulose hydrolysis (Mosier et al., 2005). Dilute sulphuric acid has been widely used to pretreat sugar cane bagasse (Van Zyl et al., 1989; Martin et al., 2002) and results in the hemicellulose fraction being released directly as pentoses such as xylose and arabinose. Without detoxification, the subsequent fermentation can be seriously inhibited. Alkali pretreatment generally leaves the hemicellulose fraction relatively intact. The ammonia freeze explosion (AFEX) process is a particularly attractive pretreatment of sugar cane bagasse (Holtzapple et al., 1991) as ammonia can be potentially recycled while only some hemicellulose is removed and the formation of sugar degradation products isminimized (Mosier et al., 2005). Furthermore this process enables both the cellulose and hemicellulose fractions to be hydrolyzed enzymatically. The objective of this task is to develop and optimize a process using enzymatic hydrolysis to produce individual C5 sugars. 
We evaluated the degree of hydrolysis of sugar cane bagasse pretreated by the AFEX process or ammonium hydroxide with combinations of cellulase, $\beta$-glucosidase and hemicellulase enzymes. Significant xylanase activity in enzyme cocktails appears to be required for greater hydrolysis of both glucan and xylan fractions of ammonia pretreated sugar cane bagasse.

Sugar cane bagasse is an attractive waste substrate for ethanol bioconversion. Approximately 24 and $38 \%$ (dry weight) of bagasse consists of hemicellulose and cellulose, respectively, and bioconversion of both fractions to ethanol must be considered for $\mathrm{n}$ economically viable process. We have evaluated the degree of hydrolysis of pretreated bagasse with combinations of cellulase, $\beta$-glucosidase and hemicellulase. Ground bagasse was pretreated either by the AFEX process $(2$ $\mathrm{NH}_{3}$ : 1 biomass, $100^{\circ} \mathrm{C}, 30 \mathrm{~min}$; kindly provided by $\left.\mathrm{MBI}\right)$ or with ammonium hydroxide $(0.5 \mathrm{~g}$ $\mathrm{NH}_{4} \mathrm{OH}$ of a $28 \%(\mathrm{v} / \mathrm{v})$ per $\mathrm{g}$ dry biomass; $\left.160^{\circ} \mathrm{C}, 60 \mathrm{~min}\right)$ and in both samples, the amounts of glucan and xylan fractions remained largely intact. The enzyme activities of 14 commercial enzyme preparations and supernatants of six laboratory grown fungi were determined. Four commercial preparations and four laboratory preparation with significant xylanase activity were evaluated for their ability to boost xylan hydrolysis when used in combination with cellulase and $\beta$-glucosidase (10 FPU: $20 \mathrm{CBU} / \mathrm{g}$ glucan). When evaluated at a $1 \%$ glucan loading, one commercial enzyme preparation (added at $10 \%$ level of total enzyme protein) boosted xylan hydrolysis by at least $40 \%$ of both pretreated bagasse samples. The glucan hydrolysis was also boosted by the xylanase. Xylanase addition at $10 \%$ protein level also improved hydrolysis of xylan and glucan fractions up to $10 \%$ glucan loading (28\% solids loading). Significant xylanase activity in enzyme cocktails appears to be required for greater hydrolysis of both glucan and xylan fractions of ammonia pretreated sugar cane bagasse.

\section{Results}

Table 22 shows the composition of sugar cane bagasse and the bagasse after treatment with the AFEX process or with ammonium hydroxide. The pretreatment process resulted in an increase in the glucan concentration especially in the ammonium hydroxide pretreated bagasse. Both pretreatment processes left the hemicellulose fraction of bagasse largely intact.

Table 22. Composition analysis (g/100 g dry biomass) of ammonium hydroxide- and AFEXtreated sugar cane bagasse

\begin{tabular}{|l|l|l|l|}
\hline Component & $\begin{array}{l}\text { Raw sugar cane } \\
\text { bagasse }\end{array}$ & $\begin{array}{l}\text { Pretreated sugar } \\
\text { cane bagasse }\end{array}$ & \\
\hline & & $\begin{array}{l}0.02 \mathrm{~g} \mathrm{NH}_{3} / 100 \mathrm{~g} \\
\mathrm{H}_{2} \mathrm{O}, 160^{\circ} \mathrm{C}, 1 \mathrm{~h}\end{array}$ & $\begin{array}{l}\text { AFEX }\left(2 \mathrm{NH}_{3}: 1\right. \\
\text { biomass, } 100^{\circ} \mathrm{C}, 30 \\
\text { min })\end{array}$ \\
\hline Ash & 2.8 & 10.0 \\
\hline Ethanol extractives & 1.1 & 3.9 & 5.8 \\
\hline Acid soluble lignin & 5.3 & 5.0 & 8.2 \\
\hline Acid insoluble lignin & 19.7 & 16.1 & 14.4 \\
\hline Glucan & 38.4 & 56.6 & 41.7 \\
\hline Xylan & 24.1 & 24.0 & 20.4 \\
\hline
\end{tabular}




\begin{tabular}{|l|l|l|l|}
\hline Arabinan & 1.9 & 1.2 & 1.2 \\
\hline Mannan & 0 & 1.7 & 1.5 \\
\hline
\end{tabular}

The cellulolytic activities of 14 commercial preparations are shown in Table 23. Filter paper activity could only be detected in some samples and the highest activities were obtained in BioCat xylanase (sample 1), Spezyme CP (sample 8) and Fibrezyme LBL (sample 12). Samples showed a considerable range in CMCase (an indicator of endo- $\beta-1,4$-glucanase), avicelase (an indicator of exoglucanase) and $\beta$-glucanase activities. BioCat products showed high activities of the various cellulolytic enzymes (samples 1, 4). Novozym 188 (sample 5) as expected had the highest $\beta$-glucosidase activity.

Table 23. Specific activities (mean of triplicate determinations \pm standard deviation) of cellulolytic enzymes in commercial preparations

\begin{tabular}{|c|c|c|c|c|c|c|c|}
\hline Enzyme & $\begin{array}{c}\text { Protein } \\
\text { Conc }\end{array}$ & $\begin{array}{l}\text { Filter } \\
\text { paper }\end{array}$ & $\begin{array}{c}\beta- \\
\text { glucanase }\end{array}$ & $\begin{array}{l}\text { Endo- } \\
\text { glucanase }\end{array}$ & $\begin{array}{c}\text { Exo- } \\
\text { glucanase }\end{array}$ & $\begin{array}{l}\text { Cellobiohydral } \\
\text { ase }\end{array}$ & $\begin{array}{c}\beta- \\
\text { glucosid } \\
\text { ase }\end{array}$ \\
\hline & & activity & & (CMCase) & (Avicelase) & & \\
\hline & $\mathrm{mg} / \mathrm{ml}$ & Units/mg & $\begin{array}{c}\mu \mathrm{mol} / \mathrm{min} / \\
\mathrm{mg}\end{array}$ & $\begin{array}{c}\mu \mathrm{mol} / \mathrm{min} / \mathrm{m} \\
\mathrm{g}\end{array}$ & $\begin{array}{c}\mu \mathrm{mol} / \mathrm{min} / \\
\mathrm{mg}\end{array}$ & $\mu \mathrm{mol} / \mathrm{min} / \mathrm{mg}$ & $\begin{array}{c}\mu \mathrm{mol} / \mathrm{mi} \\
\mathrm{n} / \mathrm{mg}\end{array}$ \\
\hline BioCat xylanase $10 \mathrm{mg} / \mathrm{ml}$ & $0.51 \pm 0.01$ & 1.43 & $69.4 \pm 9.7$ & $78.6 \pm 10.5$ & $9.50 \pm 0.79$ & $1.27 \pm 0.05$ & $\begin{array}{c}4.65 \pm 0.2 \\
6 \\
\end{array}$ \\
\hline $\begin{array}{l}\text { BioCat hemicellulase } 10 \\
\mathrm{mg} / \mathrm{ml}\end{array}$ & $0.52 \pm 0.01$ & 0.67 & $63.9 \pm 10.1$ & $41.7 \pm 10.2$ & $11.43 \pm 0.61$ & $2.12 \pm 0.24$ & $\begin{array}{c}1.77 \pm 0.3 \\
6\end{array}$ \\
\hline $\begin{array}{l}\text { T. lanuginosus xylanase, } 10 \\
\mathrm{mg} / \mathrm{ml}\end{array}$ & $0.08 \pm 0.03$ & ND & $35.4 \pm 1.1$ & $164.8 \pm 60.5$ & $33.32 \pm 3.88$ & $16.76 \pm 8.36$ & $\begin{array}{c}1.33 \pm 1.0 \\
3\end{array}$ \\
\hline BioCat cellulase, $10 \mathrm{mg} / \mathrm{ml}$ & $0.55 \pm 0.05$ & ND & $106.7 \pm 17.6$ & $79.5 \pm 6.1$ & $8.64 \pm 0.61$ & $2.05 \pm 0.31$ & $\begin{array}{c}8.11 \pm 0.7 \\
9\end{array}$ \\
\hline Novozym 188 & $38.01 \pm 1.2$ & 0 & $1.9 \pm 0.1$ & $1.0 \pm 0.2$ & $0.35 \pm 0.05$ & $0.25 \pm 0.11$ & $\begin{array}{l}14.75 \pm 0 . \\
45\end{array}$ \\
\hline Multifect xylanase & $7.63 \pm 0.39$ & 0.04 & $3.1 \pm 0.8$ & $6.3 \pm 0.6$ & $0.46 \pm 0.07$ & $0.28 \pm 0.14$ & $\begin{array}{c}3.30 \pm 0.1 \\
0\end{array}$ \\
\hline $\begin{array}{l}\text { T. reesei ATCC } 26921 \\
\text { cellulase }\end{array}$ & $\begin{array}{c}26.10 \pm 1.7 \\
8\end{array}$ & ND & $50.1 \pm 5.9$ & $32.2 \pm 3.8$ & $0.21 \pm 0.02$ & $0.88 \pm 0.11$ & $\begin{array}{c}1.10 \pm 0.2 \\
8\end{array}$ \\
\hline
\end{tabular}




\begin{tabular}{c|c|c|c|c|c|c|c|} 
Spezyme CP & $\begin{array}{c}51.81 \pm 5.6 \\
6\end{array}$ & 1.4 & $57.9 \pm 11.0$ & $21.8 \pm 2.1$ & $0.09 \pm 0.02$ & $1.79 \pm 0.05$ & $\begin{array}{c}1.82 \pm 0.0 \\
8\end{array}$ \\
\hline Cellulase from Aspergillus & $4.90 \pm 0.58$ & ND & $15.7 \pm 4.6$ & $16.5 \pm 3.7$ & $0.06 \pm 0.05$ & $0.05 \pm 0.02$ & $0.02 \pm 0$ \\
\hline GC 220 & $\begin{array}{c}56.63 \pm 8.6 \\
8\end{array}$ & ND & $85.0 \pm 18.0$ & $25.2 \pm 6.2$ & $0.13 \pm 0.01$ & $2.59 \pm 0.04$ & $\begin{array}{c}3.84 \pm 0.2 \\
8\end{array}$ \\
\hline PowerPulp TX200A & $3.34 \pm 0.07$ & 0.42 & $3.4 \pm 1.2$ & $5.6 \pm 2.0$ & $0.31 \pm 0.09$ & $0.06 \pm 0.03$ & $\begin{array}{c}1.07 \pm 0.1 \\
3\end{array}$ \\
\hline FibreZyme LBL & $\begin{array}{c}28.81 \pm 1.0 \\
0\end{array}$ & 1.27 & $66.5 \pm 8.5$ & $97.1 \pm 7.6$ & $0.38 \pm 0.05$ & $1.61 \pm 0.12$ & $\begin{array}{c}3.09 \pm 0.2 \\
1\end{array}$ \\
\hline FibreZyme LWT & $\begin{array}{c}33.61 \pm 1.8 \\
6\end{array}$ & ND & $91.5 \pm 19.8$ & $123.1 \pm 7.4$ & $0.41 \pm 0.02$ & $2.87 \pm 0.18$ & $\begin{array}{c}2.66 \pm 0.0 \\
8\end{array}$ \\
\hline BioAce & $\begin{array}{c}37.94 \pm 4.2 \\
9\end{array}$ & ND & $88.1 \pm 21.2$ & $114.6 \pm 3.5$ & $1.25 \pm 0$ & $2.82 \pm 0.07$ & $\begin{array}{c}1.82 \pm 0.0 \\
5\end{array}$ \\
\hline
\end{tabular}

Table 24 shows the hemicellulolytic specific activities of the 14 commercial samples. $\beta$-xylanase activities ranged between 10 and $2967 \mathrm{U} / \mathrm{mg}$. Especially notable was the low $\beta$-xylanase activities of Novozym 188 (sample 5) and Spezyme CP (sample 8), two enzyme preparations commonly used in the hydrolysis of lignocellulose (ref?). The purpose of the analysis was to establish the hemicellulolytic enzyme profile that might be appropriate for addition to a cellulase/ $\beta$-glucosidase enzyme mixture. The most suitable enzyme preparations were identified as BioCat xylanase, BioCat hemicellulase. T. lanuginous xylanase, Multifect xylanase, PowerPulp TX200A and FibreZyme LBL. These six preparations showed the highest xylanase specific activity. Furthermore BioCat xylanase, Multifect xylanase, and PowerPulp TX200A revealed specific $\beta$-xylosidase activity greater than one and BioCat xylanase and Multifect xylanase were found to have the highest $\alpha$-arabinofuranosidase activity. These results suggest that BioCat xylanase, Multifect xylanase, PowerPulp TX200A and FibreZyme LBL might be the best hemicellulolytic enzyme preparations that should be added to a cellulase/ $\beta$-glucosidase enzyme mixture in order to achieve the most effective hydrolysis of sugar cane bagasse to a mixture of hexoses and pentoses. 
Table 24. Specific activities (mean of triplicate determinations \pm standard deviation) of hemicellulolytic enzymes in commercial preparations

\begin{tabular}{|c|c|c|c|c|}
\hline Sample & Enzyme & $\beta$-xylanase & $\beta$-xylosidase & $\begin{array}{l}\alpha- \\
\text { arabinofuranosidase }\end{array}$ \\
\hline & preparation & & & \\
\hline & & $\mu \mathrm{mol} / \mathrm{min} / \mathrm{mg}$ & $\mu \mathrm{mol} / \mathrm{min} / \mathrm{mg}$ & $\mu \mathrm{mol} / \mathrm{min} / \mathrm{mg}$ \\
\hline 1 & $\begin{array}{c}\text { BioCat xylanase } 10 \\
\mathrm{mg} / \mathrm{ml}\end{array}$ & $1235 \pm 57$ & $5.87 \pm 0.31$ & $5.07 \pm 0.45$ \\
\hline 2 & $\begin{array}{c}\text { BioCat hemicellulase } 10 \\
\mathrm{mg} / \mathrm{ml}\end{array}$ & $609 \pm 20$ & $0.82 \pm 0.09$ & $0.39 \pm 0.10$ \\
\hline 3 & $\begin{array}{l}\text { T. lanuginosus xylanase, } \\
10 \mathrm{mg} / \mathrm{ml}\end{array}$ & $2967 \pm 18$ & $0.11 \pm 0.09$ & $1.18 \pm 0.07$ \\
\hline 4 & $\begin{array}{c}\text { BioCat cellulase, } 10 \\
\mathrm{mg} / \mathrm{ml}\end{array}$ & $36 \pm 1$ & $0.80 \pm 0.10$ & $0.55 \pm 0.06$ \\
\hline 5 & Novozym 188 & $10 \pm 1$ & $0.22 \pm 0$ & $0.09 \pm 0.1$ \\
\hline 6 & Multifect xylanase & $209 \pm 10$ & $4.90 \pm 0.58$ & $3.21 \pm 0.40$ \\
\hline 7 & $\begin{array}{l}\text { T. reesei ATCC } 26921 \\
\text { cellulase }\end{array}$ & $20 \pm 1$ & $2.11 \pm 0.23$ & $1.29 \pm 0.05$ \\
\hline 8 & Spezyme CP & $15 \pm 2$ & $0.56 \pm 0.02$ & $0.38 \pm 0.04$ \\
\hline 9 & $\begin{array}{l}\text { Cellulase from } \\
\text { Aspergillus }\end{array}$ & $49 \pm 10$ & $0.01 \pm 0.01$ & $0.01 \pm 0$ \\
\hline 10 & GC 220 & $20 \pm 2$ & $0.06 \pm 0.01$ & $0.02 \pm 0$ \\
\hline 11 & PowerPulp TX200A & $369 \pm 10$ & $1.27 \pm 0.01$ & $0.98 \pm 0.04$ \\
\hline 12 & FibreZyme LBL & $69 \pm 1$ & $0.94 \pm 0.03$ & $0.68 \pm 0.03$ \\
\hline 13 & FibreZyme LWT & $56 \pm 1$ & $1.48 \pm 0.10$ & $0.93 \pm 0.04$ \\
\hline 14 & BioAce & $22 \pm 1$ & $1.33 \pm 0.03$ & $0.88 \pm 0.01$ \\
\hline
\end{tabular}

The cellulolytic and hemicellulolytic enzyme profiles of number of selected fungi were evaluated The selection of the fungi was based on their properties determined in previous research. A. carneus ABO374 was isolated from soil in the Southern Cape region of South Africa and found to efficiently release reducing sugars from wheat straw. The supernatant of this strain cultivated on wheat straw also improved digestibility of wheat straw in in vitro and field sheep feeding trials (WH van Zyl, A. Botha, CW Cruywagen \& B. A. Prior. 2005. Unpublished data). The $T$. lanuginosus strains SSBP and ATCC 34626 were shown to be very efficient producers of xylanases and the $\beta$-xylanase activity maintained up to $60^{\circ} \mathrm{C}$ (Singh et al., 2000a; Singh et al., 2000b). A. carneus cultivated on AFEX pretreated sugar cane bagasse produced the highest specific activities of cellulolytic enzymes and $\beta$-glucosidase. T. lanuginosus strain SSBP produced lower cellulolytic specific activities when compared with the ATCC 34626 when cultivated under similar conditions. Most activities of cellulolytic enzymes were higher when strain ATCC 34626 was grown on beechwood xylan rather than for AFEX-pretreated bagasse suggesting that the pure xylan is a better substrate for this enzymatic prep. The highest specific $\beta$-xylanase activity was produced by strain ATCC 34626 when cultivated on beechwood xylan 
whereas lower activity was found when the $T$. lanuginosus strains were grown on AFEXpretreated bagasse and very little $\beta$-xylanase was produced by $A$. carneus. These results also revealed that the T. lanuginosus strains SSBP and ATCC 34626 yielded the highest specific xylanase specific activities and these values are higher thanthose found in most commercially available samples with the exception of the commercial $T$. lanuginosus xylanase which is apparently a recombinant enzyme. A. carneus produced the highest activity of $\beta$-xylosidase and $\alpha$-arabinofuranosidase whereas the $T$. lanuginosus strains produced much lower activities of these auxiliary enzymes as has been previously reported (Singh et al., 2000a).

In a simultaneous saccharification and fermentation (SSF) to ethanol process, the temperature is restricted to $30^{\circ} \mathrm{C}$ if a yeast strain such as $S$. cerevisiae is used. Therefore the activities of the $\beta$ xylanase were evaluated at $50^{\circ} \mathrm{C}$ (which is closer to optimum for many of the enzymes selected) and $30^{\circ} \mathrm{C}$ (which would appropriate for a SSF process). The activity of most $\beta$-xylanases was lower at $30^{\circ} \mathrm{C}$ than at $50^{\circ} \mathrm{C}$. However, the activities of Multifect, PowerPulp and FibreZymeLBL $\beta$-xylanases were only slightly lower or not significantly diminished at the fermentation temperature. The other activities of the commercial and laboratory produced $\beta$ xylanases were much lower at $30^{\circ} \mathrm{C}$ than at $50^{\circ} \mathrm{C}$.

Spezyme CP is a commercially marketed cellulolytic enzyme preparation produced by Trichoderma reesei that has been widely used in the hydrolysis of cellulose-rich biomass due to the dominance of endoglucanases and exoglucanases in the preparation. However this preparation lacks adequate $\beta$-glucosidase activity (Lynd et al., 2002) to achieve complete hydrolysis to glucose and, as a result, there is an accumulation of cellobiose. Therefore Spezyme $\mathrm{CP}$ is usually supplemented with $\beta$-glucosidase in order to promote complete hydrolysis. In the literature the ratios of cellulase to $\beta$-glucosidase have ranged widely and have depended upon the nature of the lignocellulose material to be hydrolysed. For example Berlin et al. (2005) used a ratio of 1 FPU: 2CBU to hydrolyse various softwood substrates, Martin et al. (2002) used a ratio of 1 FPU: 5.4 CBU while the NREL procedure (LAP-009) recommended a ratio of approximately 1 FPU: 1 pNPGU to hydrolyze stream pretreated sugar cane bagasse. A ratio of 1 FPU: 2 CBU was selected for hydrolysis experiments here and the ratio was based on the reported commercial enzyme activities of $60 \mathrm{FPU} / \mathrm{ml}$ for Spezyme CP and $282 \mathrm{CBU} / \mathrm{ml}$ for Novozym 188. Based on the data in Table 23, my calculation was 1 FPU Spezyme CP: 3.3 pNPGU Novozym 188.

Table 25 shows the effect of three levels of Spezyme CP/Novozym 188 (in an activity ratio of $1: 2)$ on the hydrolysis of ammonium hydroxide-pretreated and AFEX-pretreated bagasse and Avicel. As the enzyme level increased, greater amounts of glucose and xylose were released from the bagasse samples and glucose from the Avicel. No cellobiose was detected in any of the samples suggesting that the $\beta$-glucosidase activity was not limiting in any of the enzyme mixtures. Arabinose was only released from the AFEX-pretreated bagasse. At a 10 FPU: 20 $\mathrm{CBU} / \mathrm{g}$ glucan ratio, the greatest amount of glucose was released from Avicel followed by the AFEX-pretreated bagasse. At the lowest enzyme level only $28 \%$ and $33 \%$ of the glucan in respective $\mathrm{NH}_{4} \mathrm{OH}$ - and AFEX-pretreated bagasse samples were hydrolyzed to glucose whereas $66 \%$ of the Avicel glucan was hydrolyzed suggesting that some glucan was inaccessible in the bagasse samples to enzyme hydrolysis. At the highest enzyme level (60 FPU: $120 \mathrm{CBU}$ ), $68 \%$ and $78 \%$ of the glucan was hydrolyzed in the respective bagasse samples and Avicel samples. 
Increasing the level of enzyme appeared to have a much lower impact on the hydrolysis of the Avicel sample that the bagasse samples. This might be due to a synergistic effect of the other enzymes present in the Spezyme CP/Novozym 188 acting on the cellulose and hemicellulose components in bagasse.

Table 25. Sugar release from ammonium hydroxide- and AFEX pretreated sugar cane bagasse (at $1 \%$ glucan level) by Spezyme CP and Novozym 188 (1:2 ratio activity)

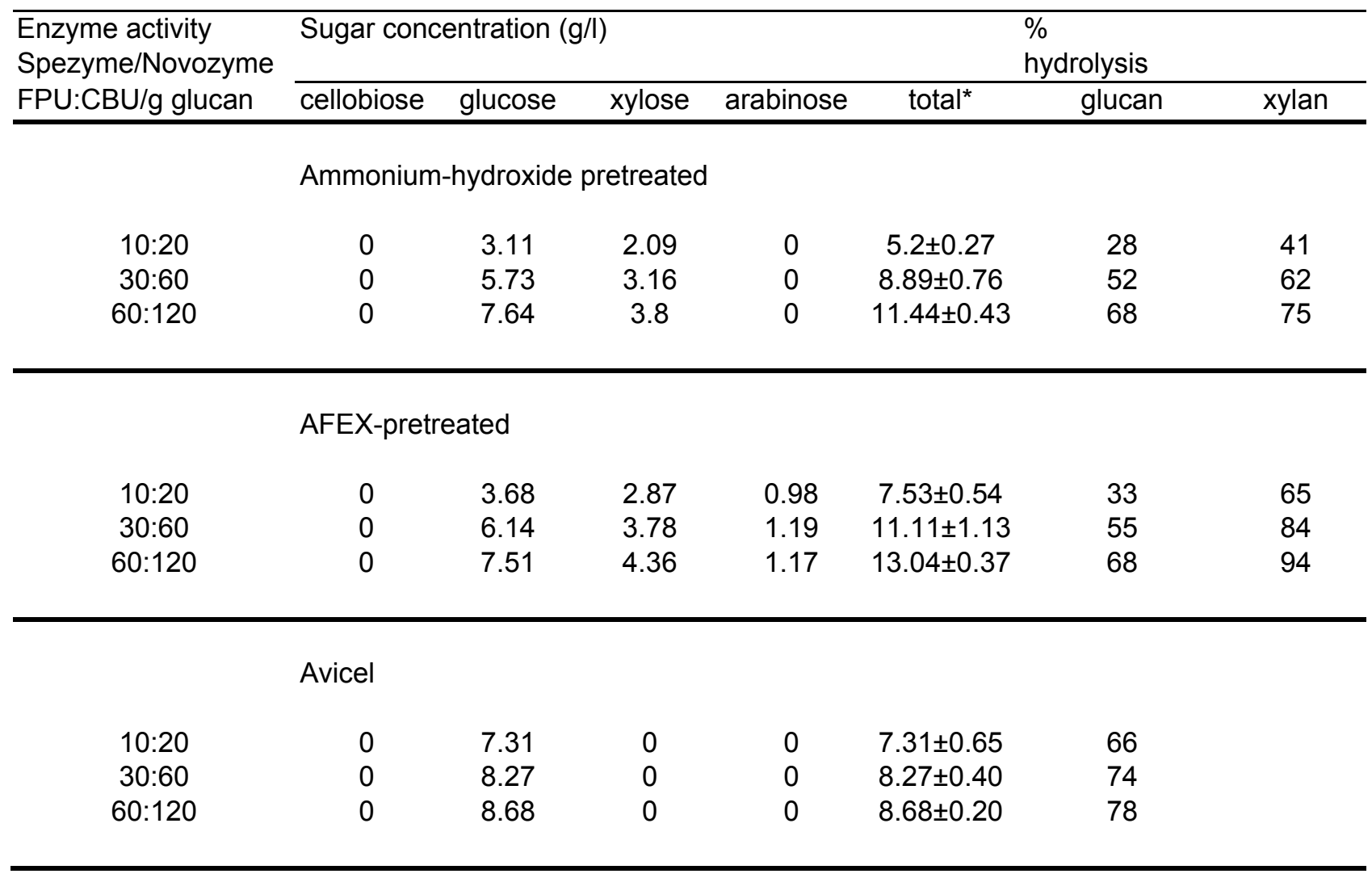

Four xylanase preparations with suitable activity profiles were evaluated for their ability to boost the hydrolysis by Spezyme CP and Novozym 188 (10 FPU: $20 \mathrm{CBU} / \mathrm{g}$ glucan) of $\mathrm{NH}_{4} \mathrm{OH}-$ (Table 26) and AFEX-pretreated bagasse (Table 27) and Avicel (Table 28). These enzyme preparations contained multiple cellulolytic and hemicellulolytic activities, therefore the total protein concentration was used as the basis to supplement the Spezyme CP/Novozym mixture instead of using the activity of a single enzyme such as xylanase. Table 26 shows that at a $10 \%$ protein level, Multifect and BioCat xylanase had a significant increase in total sugar release compared withthe control whereas with PowerPulp xylanase and FibreZyme LBL xylanase no increase was found. When the enzymatic preparations were added at $50 \%$ protein level, significant increases were observed in all instances. No cellobiose was detected. In spite of the hydrolysis increasing from $31 \%$ to respectively 43, 44 and $55 \%$ when Multifect, FibreZyme LBL and BioCat xylanases were added at the $50 \%$ protein level, the degree of hydrolysis remained low. The hydrolysis of AFEX-pretreated bagasse was boosted significantly by the addition of a $10 \%$ level of Multifect and BioCat xylanase to Spezyme CP and Novozym 188 (10 FPU: $20 \mathrm{CBU} /$ glucan) and at a $50 \%$ level, all the xylanase preparation increased significantly (Table 27). Interestingly the release of glucose also increased markedly and the degree of the 
glucan hydrolysis increased from $39 \%$ to respectively $61 \%$ and $73 \%$ by the addition of Multifect and BioCat xylanase at the $50 \%$ protein level.

Table 26.

Effect of addition of commercial xylanase preparation to hydrolysis of ammonium hydroxide pretreated

sugar cane bagasse by Spezyme CP (10FPU/g glucan)/Novozym 188 (20CBU/g glucan)

\begin{tabular}{lccccccc}
\hline $\begin{array}{l}\text { Enzyme } \\
\text { preparation }\end{array}$ & $\begin{array}{c}\text { \% protein Sugar (g/l) } \\
\text { loading }\end{array}$ & Cellobiose & Glucose & Xylose & Arabinose & Total $^{*}$ & $\begin{array}{c}\text { Glucan } \\
\text { hydrolysis }\end{array}$ \\
\cline { 3 - 8 } & & & & & & & \\
\hline None & 0 & ND & 3.49 & 1.94 & 0.26 & $5.64 \pm 0.34$ & 31 \\
Multifect & 10 & ND & 4.3 & 2.72 & ND & $7.02 \pm 0.84$ & 39 \\
& 50 & ND & 4.76 & 2.9 & ND & $7.66 \pm 1.43$ & 43 \\
Power pulp & 10 & ND & 2.57 & 1.67 & 0.18 & $4.42 \pm 0.45$ & 23 \\
& 50 & ND & 3.88 & 2.19 & 0.18 & $6.24 \pm 0.64$ & 35 \\
FibreZyme LBL & 10 & ND & 3.31 & 1.97 & 0.17 & $5.44 \pm 0.27$ & 30 \\
& 50 & ND & 4.88 & 2.55 & 0.55 & $7.98 \pm 1.20$ & 44 \\
BioCat xylanase & 10 & ND & 3.7 & 2.22 & 0.13 & $6.05 \pm 0.45$ & 33 \\
& 50 & ND & 6.1 & 2.83 & 0.28 & $9.21 \pm 0.19$ & 55 \\
\hline
\end{tabular}

ND: not detected

${ }^{*}$ mean of triplicate determinations \pm standard deviation

Table 27. Effect of addition of commercial xylanase preparation to hydrolysis of AFEXpretreated sugar cane bagasse by Spezyme CP (10FPU/g glucan)/Novozyme 188 (20CBU/g glucan) (triplicate determinations)

\begin{tabular}{|c|c|c|c|c|c|c|c|c|}
\hline \multirow{2}{*}{$\begin{array}{l}\text { Enzyme } \\
\text { preparation }\end{array}$} & \multirow{2}{*}{$\begin{array}{c}\% \\
\text { protein } \\
\text { loading }\end{array}$} & \multirow{2}{*}{$\begin{array}{l}\text { Sugar } \\
\text { (g/l) } \\
\text { Cellobios } \\
\text { e }\end{array}$} & \multirow[b]{2}{*}{ Glucose } & \multirow[b]{2}{*}{ Xylose } & \multirow[b]{2}{*}{$\begin{array}{l}\text { Arabinos } \\
\mathrm{e}\end{array}$} & \multirow[b]{2}{*}{ Total } & \multicolumn{2}{|c|}{$\%$ hydrolysis } \\
\hline & & & & & & & $\begin{array}{c}\text { Gluca } \\
n\end{array}$ & $\begin{array}{c}\text { Xyla } \\
\mathrm{n}\end{array}$ \\
\hline None & 0 & ND & 4.32 & 2.86 & 0.38 & $7.57 \pm 0.30$ & 39 & 55 \\
\hline \multirow[t]{2}{*}{ Multifect } & 10 & ND & 4.94 & 3.99 & 0.66 & $9.59 \pm 0.51$ & 44 & 62 \\
\hline & 50 & ND & 6.77 & 4.65 & 0.73 & $12.15 \pm 1.28$ & 61 & 91 \\
\hline \multirow[t]{2}{*}{ Power pulp } & 10 & ND & 4.79 & 3.29 & 0.29 & $8.37 \pm 0.82$ & 43 & 61 \\
\hline & 50 & 0.05 & 5.98 & 3.78 & 0.24 & $10.05 \pm 2.31$ & 54 & 68 \\
\hline \multirow[t]{2}{*}{ FibreZyme LBL } & 10 & 0.01 & 4.49 & 3.28 & 0.24 & $8.02 \pm 0.10$ & 41 & 60 \\
\hline & 50 & 0.01 & 6.16 & 3.79 & 0.46 & $10.43 \pm 1.20$ & 55 & 72 \\
\hline \multirow{2}{*}{$\begin{array}{l}\text { BioCat } \\
\text { xylanase }\end{array}$} & 10 & ND & 5.91 & 3.96 & 0.29 & $10.16 \pm 0.58$ & 53 & 72 \\
\hline & 50 & 0.09 & 7.97 & 4.3 & 0.34 & $12.69 \pm 1.56$ & 73 & 79 \\
\hline
\end{tabular}

ND: not detected

${ }^{*}$ mean of triplicate determinations \pm standard deviation 
Table 28.

Effect of addition of commercial xylanase preparation to hydrolysis of Avicel by Spezyme CP (10FPU/g glucan)/Novozym 188 (20CBU/g glucan) (triplicate determinations)

\begin{tabular}{|c|c|c|c|c|c|}
\hline Enzyme & $\%$ protein & Sugar $(g / l)$ & & & $\%$ \\
\hline $\begin{array}{l}\text { preparatio } \\
\text { n }\end{array}$ & loading & Cellobiose & Glucose & Total $^{*}$ & hydrolysis \\
\hline None & 0 & 0.02 & 7.27 & $7.29 \pm 0.31$ & 65 \\
\hline Multifect & 10 & ND & 6.58 & $6.58 \pm 0.51$ & 59 \\
\hline & 50 & ND & 8.49 & $8.49 \pm 0.92$ & 76 \\
\hline Power & 10 & 0.04 & 7.96 & $7.96 \pm 0.01$ & 72 \\
\hline & 50 & 0.05 & 8.81 & $8.86 \pm 0.36$ & 80 \\
\hline
\end{tabular}

ND: not detected

${ }^{*}$ mean of triplicate determinations \pm standard deviation

An analysis of the relationship between xylanase activity added and sugar release found that increasing units of enzyme activity greatest greater impact on the release of glucose than on xylose (to be evaluated statistically). Obviously this preparation contains a mixture of activities, making it difficult to remove C-5 and preserve C-6 sugars separately.

The interaction between xylanase and the release of glucose from glucan was further evaluated by adding Multifect and PowerPulp xylanases to Spezyme CP and Novozym 188 in the hydrolysis of Avicel. Table 28 shows that both Multifect and PowerPulp xylanases boosted the amount of hydrolysis significantly when added as protein at $50 \%$ the protein concentration of the Spezyme ( a $50 \%$ protein level) whereas at $10 \%$ protein level only the Power Pulp xylanase had a significant impact. PowerPulp and Multifect xylanase added at a50\% protein level increased the hydrolysis from $65 \%$ to $80 \%$ and $76 \%$ respectively. Table 3 shows that both xylanase preparations had relatively low cellulolytic enzyme activities and therefore these results suggest that the xylanase might act synergistically in the hydrolysis of cellulose by cellulase. Perhaps it permits easier access to the cellulose through the removal of C-5 sugars. This suggestion needs to be confirmed by further investigation.

The impact of laboratory-produced enzymes added at a $10 \%$ protein level on the hydrolysis by Spezyme CP and Novozym 188 is shown in Table 29. Enzymes produced by A. carneus failed to boost the hydrolysis of $\mathrm{NH}_{4} \mathrm{OH}$ - and AFEX-pretreated bagasse. The enzyme preparation produced by T. lanuginosus ATCC 34626 grown on beechwood xylan was the most effective of the various laboratory produced enzyme preparations in increasing the amount of glucose, xylose and total sugar released. The percent hydrolysis of the glucan fraction of $\mathrm{NH}_{4} \mathrm{OH}-$ and AFEXpretreated bagasse increased respectively from $32 \%$ to $40 \%$ and from $49 \%$ to $54 \%$. As shown in the studies with the commercial xylanase preparations, greater amounts of sugar were released from the AFEX-pretreated bagasse than the $\mathrm{NH}_{4} \mathrm{OH}$-pretreated bagasse when the laboratoryproduced enzymes were added to Spezyme CP and Novozym 188 suggesting that the AFEXpretreated bagasse is more easily hydrolyzed. 
Table 29 .

Effect of addition of concentrated lab xylanase preparations (10\% protein) to hydrolysis of pretreated

sugar cane bagasse (1 \% glucan) by Spezyme CP (10FPU/g glucan)/Novozyme 188 (20CBU/g glucan)

Organism

Growth

Sugar

$(\mathrm{g} / \mathrm{l})$ $\%$

conditions Cellobio Glucose Xylose Arabinos Total* Gluca Xyla hydrolysis se e $\mathrm{n} \quad \mathrm{n}$

Ammonium hydroxide pretreated bagasse

\begin{tabular}{|c|c|c|c|c|c|c|c|}
\hline A. carneus $\mathrm{ABO} 372$ & AFEX & 0.06 & 3.23 & 2.32 & 0.18 & $\begin{array}{c}5.80 \pm 0.4 \\
3\end{array}$ & 30 \\
\hline T. lanuginosus SSBP & AFEX & 0.07 & 4.17 & 3.16 & 0.22 & $\begin{array}{c}7.62 \pm 0.1 \\
4\end{array}$ & 39 \\
\hline T. lanuginosus ATCC 34626 & AFEX & ND & 3.74 & 2.82 & 0.3 & $\begin{array}{c}6.87 \pm 0.7 \\
8\end{array}$ & 34 \\
\hline T. lanuginosus ATCC 34626 & $\begin{array}{c}\text { Beechwoo } \\
\text { d }\end{array}$ & ND & 4.41 & 3.41 & 0.25 & $\begin{array}{c}8.07 \pm 0.9 \\
1\end{array}$ & 40 \\
\hline None & & 0.03 & 3.53 & 2.2 & 0.17 & $\begin{array}{c}5.93 \pm 0.3 \\
0\end{array}$ & 32 \\
\hline
\end{tabular}

AFEX pretreated bagasse

\begin{tabular}{|c|c|c|c|c|c|c|c|}
\hline A. carneus $\mathrm{ABO} 372$ & AFEX & 0.14 & 5 & 4.02 & 0.3 & $\begin{array}{c}9.46 \pm 0.4 \\
8\end{array}$ & 48 \\
\hline T. lanuginosus SSBP & AFEX & 0.12 & 5.51 & 4.1 & 0.27 & $\begin{array}{c}9.99 \pm 0.9 \\
6\end{array}$ & 52 \\
\hline T. lanuginosus ATCC 34626 & AFEX & 0.01 & 5.87 & 4 & 0.28 & $\begin{array}{c}10.16 \pm 0 \\
93\end{array}$ & 53 \\
\hline T. lanuginosus ATCC 34626 & $\begin{array}{c}\text { Beechwoo } \\
\text { d }\end{array}$ & ND & 6.01 & 4.55 & 0.25 & $\begin{array}{c}10.82 \pm 0 \\
71\end{array}$ & 54 \\
\hline None & & ND & 5.48 & 3.94 & 0.27 & $\begin{array}{c}9.69 \pm 0.6 \\
6\end{array}$ & 49 \\
\hline
\end{tabular}

Avicel

A. carneus ABO372

$\begin{array}{llll}\text { AFEX } & 0.08 & 9.53 & \text { ND }\end{array}$

ND $\quad 9.61 \pm 0.4 \quad 88$ 
T. lanuginosus SSBP

$\begin{array}{cccc}\text { AFEX } & 0.11 & 10.75 & \text { ND } \\ \text { AFEX } & 0.03 & 7.68 & \text { ND } \\ \begin{array}{c}\text { Beechwoo } \\ \text { d }\end{array} & 0.08 & 8.59 & \text { ND } \\ & 0.08 & 8.83 & \text { ND }\end{array}$

\begin{tabular}{ccc} 
ND & $10.86 \pm 0$. & 100 \\
& 97 & \\
ND & $7.71 \pm 0.4$ & 70 \\
& 1 & \\
ND & $8.67 \pm 0.1$ & 79 \\
& 8 & \\
ND & $8.91 \pm 0.3$ & 82 \\
& 3 & \\
\hline
\end{tabular}

Growth conditions: Fungus grown either on AFEX pretreated bagasse or beechwood xylan

ND: Not detected

*mean of triplicate determinations \pm standard deviation

As the Multifect xylanase was shown to be one of the most effective xylanase preparations in enhancing the hydrolysis of bagasse, the effect on substrate loading on the hydrolysis of $\mathrm{NH}_{4} \mathrm{OH}$ - and AFEX-pretreated bagasse by Spezyme CP and Novozym 188 with and without Multifect xylanase was evaluated (Table 30). At all substrate loading doses, there were greater amounts of xylose, arabinose and glucose released when xylanase was present. Due to the nature of the $\mathrm{NH}_{4} \mathrm{OH}$-pretreated bagasse, a maximum substrate loading of only $4 \%$ could be tested whereas the AFEX-pretreated bagasse could be tested up to a10 \% substrate loading dose. However, it was apparent that greater concentrations of both glucose and xylose were released from the AFEX-pretreated bagasse compared with $\mathrm{NH}_{4} \mathrm{OH}$-pretreated bagasse. Surprisingly the $\%$ hydrolysis of the glucan fraction of bagasse appeared to be unaffected by the load increase but the xylan hydrolysis declined with an increase in loading in the AFEX-pretreated bagasse. It is notable that there was a greater accumulation of cellobiose with an increase in the loading of the AFEX-pretreated bagasse. Furthermore the accumulation was greater in the absence of Multifect xylanase. This suggests that additional $\beta$-glucosidase activity might be necessary at higher loading doses. 
Table 30. Effect of substrate loading on hydrolysis of AFEX and NH3-pretreated sugar cane bagasse by Spezyme (10 FPU/g glucan)

and Novozyme 188 (20 CBU/g glucan) with or without Multifect xylanase added at 10 $\%$ protein (mean of triplicate determination)

\begin{tabular}{|c|c|c|c|c|c|c|c|}
\hline \multirow{3}{*}{$\begin{array}{l}\% \text { glucan } \\
\text { loading }\end{array}$} & \multicolumn{7}{|l|}{ Sugar $(g / l)$} \\
\hline & \multirow[t]{2}{*}{ Cellobiose } & \multirow[t]{2}{*}{ Glucose } & \multirow[t]{2}{*}{ Xylose } & \multirow[t]{2}{*}{ Arabinose } & \multirow[t]{2}{*}{ Total $^{*}$} & \multicolumn{2}{|c|}{$\%$ hydrolysis } \\
\hline & & & & & & glucan & xylan \\
\hline \multicolumn{8}{|c|}{$\begin{array}{l}\text { Ammonium hydroxide pretreatment } \\
\text { With xylanase }\end{array}$} \\
\hline 1 & 0.05 & 4.27 & 2.77 & 0.19 & $7.29 \pm 0.58$ & 39 & 58 \\
\hline 2 & ND & 9.21 & 6.05 & 0.49 & $15.75 \pm 0.75$ & 41 & 65 \\
\hline 4 & 0.07 & 22.93 & 13.21 & 0.99 & $37.21 \pm 1.30$ & 52 & 70 \\
\hline \multicolumn{8}{|c|}{ AFEX-pretreatment } \\
\hline 1 & 0.06 & 5.73 & 4.51 & 0.42 & $10.71 \pm 1.21$ & 53 & 84 \\
\hline 2 & 0.32 & 14.23 & 8.74 & 1.05 & $24.34 \pm 0.55$ & 67 & 83 \\
\hline 5 & 0.91 & 28.47 & 19.45 & 2.57 & $51.41 \pm 2.83$ & 55 & 75 \\
\hline 10 & 5.43 & 46.39 & 34.56 & 4.5 & $90.89 \pm 0.75$ & 52 & 66 \\
\hline
\end{tabular}

ND: not detected

*mean of triplicate determinations \pm standard deviation

\begin{tabular}{|c|c|c|c|c|c|c|}
\hline \multicolumn{7}{|l|}{ Sugar $(g / l)$} \\
\hline \multirow[t]{2}{*}{ Cellobiose } & \multirow[t]{2}{*}{ Glucose } & \multirow[t]{2}{*}{ Xylose } & \multirow[t]{2}{*}{ Arabinose } & \multirow[t]{2}{*}{ Total $^{*}$} & \multicolumn{2}{|c|}{$\%$ hydrolysis } \\
\hline & & & & & glucan & xylan \\
\hline \multicolumn{7}{|c|}{ Without xylanase } \\
\hline 0.06 & 3.76 & 2.32 & 0.18 & $6.32 \pm 0.37$ & 35 & 49 \\
\hline ND & 6.61 & 4.26 & 0.37 & $11.24 \pm 1.40$ & 30 & 46 \\
\hline ND & 17.79 & 9.93 & 0.85 & $28.57 \pm 2.34$ & 40 & 53 \\
\hline
\end{tabular}

\section{Conclusions}

Enzyme preparations were assayed for their activities and certain preparations have been identified as being more suitable for use in hydrolysis experiments of pre-treated bagasse.

\section{Methods and Materials (Task 3)}

\section{Pretreatment of sugar cane bagasse}

Bagasse from sugar cane (Saccharum officinarum) was obtained from the Raceland Raw Sugar Corp. sugar mill, Raceland, Louisiana and ground to a particle size of less than a $12 \mathrm{~mm}$ in length. Ground sugar cane bagasse has submitted to MBI International, Lansing, MI for 
pretreatment using the AFEX process (Holtzapple et al., 1991). Briefly, approximately $1 \mathrm{~kg}$ of the bagasse was treated in a one gallon reactor at $100{ }^{\circ} \mathrm{C}$ for 30 min with a $2: 1$ ammonia loading to biomass and $40 \%$ moisture level. After pretreatment, bagasse was removed from the reactor, dried to remove ammonia and stored in sealed plastic bags at $4{ }^{\circ} \mathrm{C}$. Ground sugar cane bagasse $(2.5 \mathrm{~kg})$ was also pretreated by adding a $28 \%$ stock solution of ammonium hydroxide to achieve a final concentration of $0.02 \mathrm{~g} \mathrm{NH}_{3} / \mathrm{g}$ water in a final water mass of $20 \mathrm{~kg}$. The slurry was placed in a pressure reactor and heated at $160{ }^{\circ} \mathrm{C}$ for $60 \mathrm{~min}$. The solid mass was removed from the slurry by filtration through muslin cloth and washed with $40 \mathrm{~kg}$ of water. Less than $1 \%$ of mono sugars in the bagasse were removed by this pretreatment.

\section{Analysis of the composition of sugar cane bagasse and pretreated bagasse}

The carbohydrate composition and the content of ethanol extractives, ash and lignin were determined using the analytical procedures published by DOE's NREL laboratory (wwwl.energy.gov/biomass/analytical_procedures.html). The moisture content of the bagasse samples was determined using a moisture analyzer (Computrac MAX 1000, Arizona Instrument Corporation, Tempe, Arizona).

\section{Enzyme preparations}

\section{Commercial preparations}

A commercial preparation produced by Trichoderma reesei (Spezyme CP) and supplied by Genencor (Rochester, NY) was used as the main cellulase enzyme in this study. This preparation was supplemented with a $\beta$-glucosidase preparation (Novozym 188) produced Aspergillus niger and supplied by Sigma (C6105). Various commercial enzymes with cellulose and xylanase activity were kindly provided by various North American suppliers and their cellulolytic and hemicellulolytic activities were evaluated. Some enzyme samples were in powder form and were suspended in $100 \mathrm{mM}$ sodium acetate buffer $(\mathrm{pH} \mathrm{5})$ at a concentration of $10 \mathrm{mg} / \mathrm{ml}$.

\section{Laboratory-produced enzyme preparations}

Thermomyces lanuginosus strains SSBP and ATCC 34626 and Aspergillus carneus Abo 372 were obtained from the culture collection of the Department of Microbiology at the University of Stellenbosch, South Africa. The fungi were maintained on malt extract agar plates. With a sterilized needle, colonies were inoculated into $1 \mathrm{ml} \mathrm{YPD} \mathrm{(10} \mathrm{g/1} \mathrm{yeast} \mathrm{extract,} 20 \mathrm{~g} / 1$ peptone, 20 $\mathrm{g} / 1$ glucose), and cultivated for 2 days at the optimum temperature for each of the fungal species (T. lanuginosus, $50^{\circ} \mathrm{C} ;$ A. carneus, $30^{\circ} \mathrm{C}$ ) with shaking. The contents of each inoculant were decanted into $200 \mathrm{ml}$ growth medium $(0.67 \%$ Yeast Nitrogen Base, with amino acids, 0.2\% LAsparagine monohydrate, $0.5 \% \mathrm{KH}_{2} \mathrm{PO}_{4}$ ), containing $4 \mathrm{~g}$ of AFEX pretreated sugar cane bagase or $4 \mathrm{~g}$ beechwood xylan (Sigma $\mathrm{X}$ 4252) as carbon source and cultivated for 5 days at the optimum temperature. Fungal growth was clearly visible in the flasks after 4 days. The culture fluid was filtered through 4 layers of muslin cloth and then, centrifuged at $5000 \mathrm{X} \mathrm{g}$ for $10 \mathrm{~min}$ to remove fungal debris. After centrifugation, $0.1 \%$ sodium azide was added to the supernatant 
and concentrated by filtration through an Amicon concentration apparatus using a $10 \mathrm{kDa}$ membrane filter.

\section{Enzyme and protein assays}

The filter paper activity of enzyme samples was determined at $50{ }^{\circ} \mathrm{C}$ according to standardized NREL filter paper assay (Adney \& Baker, 1996). Carboxymethylcellulase (CMCase; endoglucanase), avicelase (exoglucanase) and $\beta$-D-(1,3;1,4)-glucanase activity was determined by measuring the release of reducing sugars from respectively $3 \%$ carboxymethyl cellulose (Sigma), $3 \%$ Avicel (FMC Biopolymer $\mathrm{pH}$-102) and $0.5 \%$ barley $\beta$-glucan (Sigma) at $50^{\circ} \mathrm{C}$ and $\mathrm{pH} 5.0$ (100 mM acetate buffer) for $10 \mathrm{~min}$ (Wood and Bhat, 1988). The reaction was terminated by addition of dinitrosalicyclic acid reagent and subsequently boiled for $5 \mathrm{~min}$. The reducing sugar concentration was determined from the absorbance at $540 \mathrm{~nm}$ using a glucose standard curve as reference. One unit (IU) of activity was defined as the amount of enzyme that released $1 \mu \mathrm{mol}$ of glucose as reducing sugar equivalents per minute.

$\beta$-Xylanase activity was determined by following the release of reducing sugars from a $1.0 \%$ birchwood xylan (Sigma) solution at $50^{\circ} \mathrm{C}$ for $5 \mathrm{~min}$ (Bailey et al., 1992). The reaction was terminated by the addition of dinitrosalicyclic acid reagent and subsequently boiled for $5 \mathrm{~min}$. The reducing sugar concentration was determined spectrophotometrically at $540 \mathrm{~nm}$ from a xylose standard curve. One unit of activity was defined as the amount of enzyme that released 1 $\mu \mathrm{mol}$ of xylose as reducing sugar equivalents per minute.

Cellobiohydrolase (CBHI), $\beta$-glucosidase, $\beta$-xylosidase and $\alpha$-arabinofuranosidase activities were determined by following the release of 4-nitrophenol from their respective 4-nitrophenol conjugates:4-nitrophenyl- $\beta$-D-lactopyranoside, 4-nitrophenyl- $\beta$-D-glucopyranoside, $\quad 4$ nitrophenyl- $\beta$-D-xylopyranoside and 4-nitrophenyl- $\alpha$-L-arabinopyranoside (Sigma) for $15 \mathrm{~min}$ at $50^{\circ} \mathrm{C}$ and $\mathrm{pH} 4.0$ (50 $\mathrm{mM} \mathrm{Na}$ acetate buffer). The reaction was stopped by the addition of $1 \mathrm{M}$ $\mathrm{Na}_{2} \mathrm{CO}_{3}$ and absorbance read at $410 \mathrm{~nm}$ from a 4-nitophenol standard curve. One unit of activity was defined as the amount of enzyme that released $1 \mu \mathrm{mol}$ of 4-nitrophenol per minute.

The protein concentration was determined using the Coomassie Brilliant Blue dye-binding method (Bio-Rad; Bradford, 1976).

\section{Batch hydrolysis of pretreated sugar cane bagasse and Avicel}

Enzymatic saccharification experiments of pretreated samples were performed in triplicate in 20 $\mathrm{ml}$ glass scintillation vials at $50{ }^{\circ} \mathrm{C}$ and $100 \mathrm{rpm}$ ? for $72 \mathrm{~h}$ as described in the NREL (LAP-009) procedure. Briefly, the reaction mixture contained $0.1 \mathrm{~g}$ cellulose (dry weight) (except with the substrate loading experiment), $0.5 \mathrm{ml} 1 \mathrm{M}$ sodium citrate buffer ( $\mathrm{pH} 4.8), 40 \mu 1$ tetracycline (10 $\mathrm{mg} / \mathrm{ml}), 30 \mu \mathrm{l}$ cycloheximide $(10 \mathrm{mg} / \mathrm{ml})$, Spezyme CP and Novozym 188 in a ratio of $1: 2$ and distilled water to give a final volume of $10 \mathrm{ml}$. Adjustments were also made for the addition of various activities of commercial and laboratory-produced xylanases. The moisture content in the AFEX-pretreated bagasse $(24.53 \%)$ and $\mathrm{NH}_{4} \mathrm{OH}$-pretreated bagasse $(78.42 \%)$ was included in the calculation of the total volume. Avicel (FMC Biopolymer pH-102; $4.54 \%$ moisture) was also included as a control. Substrate blanks excluded the enzyme activities whereas enzyme blanks 
excluded the substrates and the degree of spontaneous hydrolysis was used to correct data. Samples were withdrawn initially and after $72 \mathrm{~h}$ and centrifuge at 10,000 rpm in Eppendorf tubes to remove the biomass. Subsequently the liquid portion was filtered through $0.45 \mu \mathrm{m}$ (pore size) filters $(25 \mathrm{~mm}$ (diameter) Whatman GD/X filter (PTFE filter media with polypropylene housing, Cat. No. 6874-2504, Whatman Inc. Florham Park, NJ ) and the liquid subjected to HPLC for reducing sugar analysis. HPLC analysis was conducted using an isocratic HPLC system equipped with a refractive index detector (Spectra System. RI 150, Thermo Electron Corp., Milan, Italy). Sugars were separated on a BioRad Aminex-HPX-87P column (BioRad Lab. Inc. Hercules, CA) at a flow rate for the mobile phase (DI water) of $0.6 \mathrm{ml} / \mathrm{min}$ at $85^{\circ} \mathrm{C}$ for $30 \mathrm{~min}$. Reducing sugar concentration was determined as described above. Generally, the reducing sugar concentrations agreed within $10 \%$ of the total sugar determined by HPLC. In instances where the values did not agree, analyses were repeated.

\section{Calculations}

The percent hydrolysis of the glucan fraction of sugar cane bagasse was calculated adding the glucose and double the cellobiose concentrations, correcting for the hydration (each glucose molecule had one molecule of water added during hydrolysis and therefore the glucose concentration was multiplied by 0.9 ) and dividing by the grams of glucan. Similarly, the percent hydrolysis of the xylan fraction was calculated by adding the xylose and arabinose concentrations, correcting for hydration (total xylose and arabinose was multiplied by 0.88) and dividing by the grams of total xylan and arabinan [should that be arabinose?].

\section{Task 4. Produce ethanol through fermentation of bagasse and molasses}

This task was transferred to DE-FG36-05G085007 and will be reported in full there.

In order to scale-up biomass processing an alternative pretreatment was required as the AFEX technology was not able to handle the biomass at the required scale .

An AFEX simulant, which involves ammonium hydroxide pretreatment, was tested at $10 \%$ loading of raw sugarcane bagasse to quantify selected inhibitors (i.e. lignin, total phenolic compounds, and $\mathrm{pH}$ ) formed during pretreatment and to investigate their combined effect on enzymatic hydrolysis. Also investigated was the release of sugars (i.e. glucose, cellobiose, xylose, arabinose) after treatment with increasing levels of ammonium hydroxide.

Increasing concentrations of ammonium hydroxide $\left(0-0.040 \mathrm{~g} \mathrm{NH}_{3}\right.$ per $\mathrm{g}$ of water) resulted in an increased release of TPC (0.0052 - $0.0490 \mathrm{~g}$ vanillin per $\mathrm{g}$ dry biomass $)$, lignin (0.0116-0.070 $\mathrm{g}$ beechwood per $\mathrm{ml}$ solution), and an increase in $\mathrm{pH}$ (5.0-10.8) (Table 31). A change in the treatment process from $10 \mathrm{~min}$ to $60 \mathrm{~min}$ favored the release of TPC, lignin and the formation of organic acids which caused a drop in $\mathrm{pH}$. 
Table 31. pH, Lignin and TPC removal Post-Ammonium Hydroxide Pretreatment of Sugarcane Bagasse.

\begin{tabular}{|c|c|c|c|c|c|}
\hline \multicolumn{3}{|c|}{ Treatment } & \multirow[b]{2}{*}{$\begin{array}{l}\text { Total TPC* } \\
\text { (g vanillin per } \\
\text { g dry biomass) }\end{array}$} & \multirow[b]{2}{*}{$\begin{array}{c}\text { Lignin } \\
\text { (g beechwood per } \\
\text { ml solution) } \\
\end{array}$} & \multirow[b]{2}{*}{$\begin{array}{c}\text { pH } \\
\text { Solution }\end{array}$} \\
\hline $\begin{array}{c}\text { Ammonium Hydroxide } \\
\text { (g NH} 3 \text { in solution per } \\
\text { g of water) } \\
\end{array}$ & $\begin{array}{c}\text { Temperature } \\
\left({ }^{\circ} \mathrm{C}\right)\end{array}$ & $\begin{array}{l}\text { Time } \\
\text { (min) }\end{array}$ & & & \\
\hline 0.000 & 120 & 10 & 0.0052 & 0.0120 & 5.6 \\
\hline 0.000 & 120 & 60 & 0.0060 & 0.0116 & 5.0 \\
\hline 0.002 & 120 & 10 & 0.0130 & 0.0229 & 9.5 \\
\hline 0.002 & 120 & 60 & 0.0210 & 0.0239 & 9.0 \\
\hline 0.020 & 120 & 10 & 0.0280 & 0.0419 & 10.3 \\
\hline 0.020 & 120 & 60 & 0.0430 & 0.0426 & 10.2 \\
\hline 0.040 & 120 & 10 & 0.0350 & 0.0464 & 10.8 \\
\hline 0.040 & 120 & 60 & 0.0490 & 0.0710 & 10.6 \\
\hline
\end{tabular}

No significant differences from the control were observed in the release of cellobiose, glucose, or xylose fractions following pretreatment with ammonium hydroxide. However, the release of arabinose increased with increasing concentrations of ammonium hydroxide (Table 32).

Rinsing the sugarcane bagasse with water post-ammonium hydroxide treatment removed some of the inhibitors mentioned above thus increasing cellulose and hemicellulose conversion to fermentable sugars (Table 33). A $55 \%$ or $41 \%$ cellulose conversion and $18 \%$ or $13 \%$ hemicellulose conversion were obtained for washed or unwashed treated biomass, respectively. This approach was successfully followed under the auspices of DE-FG36-05GO850 and will be fully reported elsewhere. Using this approach we can routinely achieve $90 \%$ cellulose conversion, with an SHF-SSF fermentation using a batch fed process, achieve a 30\% solid loading and, with molasses supplementation, routinely obtain greater than $5 \%$ ethanol in the beer. 
Table 32. Selected Sugars Released Post-Ammonium Hydroxide Treatment of Sugarcane Bagasse.

\begin{tabular}{|c|c|c|c|c|c|c|}
\hline \multicolumn{3}{|c|}{ Treatment } & \multicolumn{3}{c|}{ Concentration (g/L solution) } \\
\hline $\begin{array}{c}\text { Ammonium Hydroxide } \\
\text { (g NH } \mathbf{~ N h}_{\mathbf{3}} \text { in solution per } \\
\mathbf{g} \text { of water) }\end{array}$ & $\begin{array}{c}\text { Temperature } \\
\left({ }^{\circ} \mathbf{C}\right)\end{array}$ & $\begin{array}{c}\text { Time } \\
(\mathbf{m i n})\end{array}$ & Cellobiose & Glucose & Xylose & Arabinose \\
\hline 0 & & & & & & \\
\hline 0 & 120 & 10 & ND & 0.03 & ND & ND \\
\hline 0.002 & 120 & 60 & ND & 0.04 & 0.07 & ND \\
\hline 0.002 & 120 & 10 & 0.09 & 0.02 & 0.03 & ND \\
\hline 0.020 & 120 & 60 & 0.02 & 0.05 & 0.06 & 0.06 \\
\hline 0.020 & 120 & 10 & ND & 0.09 & 0.03 & ND \\
\hline 0.040 & 120 & 60 & 0.04 & 0.05 & 0.02 & 0.35 \\
\hline 0.040 & 120 & 10 & 0.04 & 0.01 & 0.03 & 0.77 \\
\hline & 120 & 60 & 0.03 & 0.05 & 0.04 & 0.53 \\
\hline
\end{tabular}

$\mathrm{ND}=$ None Detected.

Table 33. Enzyme Hydrolysis Post-Ammonium Hydroxide Treatment of Sugarcane Bagasse

\begin{tabular}{|c|c|c|c|c|c|c|}
\hline \multicolumn{3}{|c|}{ Treatment } & \multicolumn{4}{|c|}{ Percent of Maximum Theoretical Yield } \\
\hline $\begin{array}{c}\text { Ammonium } \\
\text { Hydroxide } \\
\text { (g } \mathrm{NH}_{3} \text { in solution } \\
\text { per } \\
\text { g of water) }\end{array}$ & $\begin{array}{c}\text { Temperature } \\
\left({ }^{\circ} \mathrm{C}\right)\end{array}$ & $\begin{array}{l}\text { Time } \\
\text { (min) }\end{array}$ & $\begin{array}{c}\text { Cellulose } \\
\text { Hydrolyzation } \\
\text { (Washed) } \\
\end{array}$ & $\begin{array}{c}\text { Hemicellulose } \\
\text { Hydrolyzation } \\
\text { (Washed) } \\
\end{array}$ & $\begin{array}{l}\text { Cellulose } \\
\text { Hydrolyzation } \\
\text { (Not Washed) }\end{array}$ & $\begin{array}{l}\text { Hemicellult } \\
\text { Hydrolyzati } \\
\text { (Not Washe }\end{array}$ \\
\hline Control (AVICEL) & NA & NA & 92.0 & 0 & 92.0 & 0 \\
\hline 0.000 & 120 & 10 & 7.4 & 0.9 & 7.3 & 0.9 \\
\hline 0.000 & 120 & 60 & 6.9 & 1.0 & 8.1 & 1.1 \\
\hline 0.002 & 120 & 10 & 13.3 & 1.3 & 12.4 & 1.6 \\
\hline 0.002 & 120 & 60 & 21.1 & 4.1 & 14.2 & 2.1 \\
\hline 0.020 & 120 & 10 & 27.7 & 8.7 & 24.2 & 7.6 \\
\hline 0.020 & 120 & 60 & 45.2 & 15.5 & 37.0 & 12.5 \\
\hline 0.040 & 120 & 10 & 28.8 & 9.4 & 24.0 & 6.2 \\
\hline 0.040 & 120 & 60 & 55.2 & 18.4 & 40.7 & 12.5 \\
\hline
\end{tabular}




\section{Task 5}

\section{Thermochemical Conversion of Bagasse}

Because of the importance of Syngas production and Fischer - Tropsch conversion to ethanol as a potential biofuel process a small investigative component on pyrolysis of sugarcane biomass was undertaken in order to gain sufficient expertise in this field to evaluate its potential for a sugarmill based biorefinery. This involved two tasks.

Sub-Task 5.1. Design and execute an experimental matrix of subcritical aqueous alkalicatalyzed conversion tests with sugarcane CML solids. Characterize liquid, gas and solid products of the conversions.

The liquid products of pyrolysis were characterized. Each pyrolysis liquid sample was extracted into acidic and basic fractions, and into each of three solvents; dichloromethane, ethyl acetate, or toluene. These solvents were selected for their ability to solubilize a wide variety of species presumed to be present in pyrolysis products. Samples were run on a GC-MS. Components were selected for identification by the magnitude of their peak intensity. The product distribution was normalized based on the peak with the highest count intensity.

It was found that the acidic toluene extraction yielded the highest proportion of components, despite a wide variation in test conditions. The compound tentatively identified (NIST GSMS library) as tricyclo[5.2.1.0(1,5)]dec-5-en-8-ol $\left(\mathrm{C}_{10} \mathrm{H}_{14} \mathrm{O}\right)$ yielded the highest intensity peak for these extractions. Some of the other likely candidates are listed in Table 34.

Table 34: Preliminary Characterization of Liquid Pyrolysis Products.

\begin{tabular}{|l|c|c|}
\hline \multicolumn{1}{|c|}{ Compound } & Probability & $\begin{array}{c}\text { Molecular } \\
\text { Wt. }\end{array}$ \\
\hline $\begin{array}{l}\text { tricyclo[5.2.1.0(1,5)]dec-5-en- } \\
\text { 8-ol }\end{array}$ & 36.9 & 150 \\
\hline 1,3-dimethylbenzene & 28.5 & 106 \\
\hline paraxylene & 21.3 & 106 \\
\hline$\alpha, \beta$-dimethylbenzene ethanol & 20.1 & 150 \\
\hline
\end{tabular}

It should be noted that the NIST library searches produced several low probability matches with substances commonly found in the pharmaceutical industry (e.g., creatinine and dimethoxyphenylethylamine). A comparison with recent literature (Ind. Eng. Chem. Res., Vol. 42, No. 14, 2003) suggests, for example, that the compound identified by the NIST library as creatinine (a protein produced by muscle tissue), which had a retention time of 9.571 minutes and a probability of 44, would more likely be propionic acid methyl ester with a retention time of 9.567 minutes. 
The first four pyrolysis runs were conducted at $600^{\circ} \mathrm{C}$ and the fifth run was carried out at $850^{\circ} \mathrm{C}$. The first and last runs had no catalyst added, while the second, third, and fourth runs had $\mathrm{Na}_{2} \mathrm{CO}_{3}, \mathrm{MgO}$, and $\mathrm{CaO}$ added, respectively (shown in Table 35) in hopes of improving the methane and $\mathrm{CO}$ levels in the gas.

Table 25: The Various Conditions used in Pyrolysis Tests on Sugarcane Biomass.

\begin{tabular}{|l|l|c|c|}
\hline \multicolumn{1}{|c|}{ Run } & \multicolumn{1}{|c|}{ Catalyst } & $\begin{array}{c}\text { Soak } \\
\text { Temperature }\end{array}$ & Time at Soak \\
\hline RTA1 & None & $600^{\circ} \mathrm{C}$ & $16.10 \mathrm{~min}$ \\
\hline RTA2 & $\begin{array}{l}4.23 \mathrm{~g} \\
\mathrm{Na} 2 \mathrm{CO} 3\end{array}$ & $600^{\circ} \mathrm{C}$ & $15.00 \mathrm{~min}$ \\
\hline RTA3 & $4.40 \mathrm{~g} \mathrm{MgO}$ & $600^{\circ} \mathrm{C}$ & $15.50 \mathrm{~min}$ \\
\hline RTA4 & $4.19 \mathrm{~g} \mathrm{CaO}$ & $600^{\circ} \mathrm{C}$ & $16.10 \mathrm{~min}$ \\
\hline RTA5 & None & $850^{\circ} \mathrm{C}$ & $17.20 \mathrm{~min}$ \\
\hline
\end{tabular}

Gas chromatography revealed the largest constituent in the product gas stream to be $\mathrm{CO} 2$, followed by $\mathrm{CO}$. The last two tests, however, had markedly reduced concentrations of $\mathrm{CO} 2$, yet they were the only runs that showed evidence of methane formation. On average, the gas from the first three runs contained $84 \mathrm{wt} \% \mathrm{CO} 2$ and $16 \mathrm{wt} \% \mathrm{CO}$ with a standard deviation of $4.6 \mathrm{wt} \%$. The weight percent level of the various product gases is provided in Table 36.

Table 36: Composition of Gaseous Products of Pyrolysis Tests.

\begin{tabular}{|c|c|c|c|}
\hline Run & $\begin{array}{c}\mathbf{W t} \% \\
\mathbf{C O}_{\mathbf{2}}\end{array}$ & $\mathbf{W t} \% \mathbf{C O}$ & $\begin{array}{c}\mathbf{W t}^{\mathbf{6}} \\
\mathbf{C H}_{\mathbf{4}}\end{array}$ \\
\hline RTA1 & 83 & 17 & 0 \\
\hline RTA2 & 80 & 20 & 0 \\
\hline RTA3 & 89 & 11 & 0 \\
\hline RTA4 & 63 & 24 & 13 \\
\hline RTA5 & 52 & 41 & 7 \\
\hline
\end{tabular}

Ashing of the $\mathrm{Na}_{2} \mathrm{CO}_{3}, \mathrm{MgO}$, and $\mathrm{CaO}$ catalysts resulted in a dry weight losses of $10 \%, 1 \%$, and $23 \%$, respectively. The low weight loss for sodium carbonate indicated that carbonate was not breaking down and contributing to the formation of carbon dioxide. The approximate calculated weight loss of $42 \%$ is based on the stoichiometry of the following chemical equation:

$$
\mathrm{Na}_{2} \mathrm{CO}_{3}(\mathrm{~s}) \rightarrow \mathrm{NaO}(\mathrm{s})+\mathrm{CO}_{2}(\mathrm{~g})
$$

The weight loss, after accounting for the calcium oxide catalyst was surprisingly high. 
An important observation was made that may have an impact on the chemistry that took place in the Rotational Thermal Apparatus (RTA) pyrolysis runs (Figure 6). A plot of the oxygen concentration profiles revealed inconsistencies in the oxygen profiles during tests. The profiles



Figure 6: Oxygen Concentration Profiles from Rotational Thermal Apparatus Pyrolysis Studies.

of the third and fifth runs showed increases during the first five minutes of the reactions prior to decreasing, whereas the remaining RTA runs saw decreases in oxygen concentrations from time $\mathrm{t}=0$. Furthermore, the slope of the initial declines in oxygen concentration was fairly consistent for each of the runs, except for RTA run 1, which exhibited an unusual plateau effect while the oxygen concentrations were decreasing.

Table 37 below depicts the breakout of the mass balance for the starting material mass in terms of the liquid, solid and gaseous product portions. The gases were measured via a water displacement method and the solids were measured by weight. The organic liquid product was determined by difference. The first four runs depict a consistent gas mass of about $13 \mathrm{~g}$. The final four runs have lower mass yields for the gases but demonstrate an average liquids product mass of about $53 \mathrm{~g}$, while the first four runs average about $46 \mathrm{~g}$ of liquid product. The particularly low gas product masses in runs 5 and 6 are attributable to a possible leak in the tubing during gas collection. The presence of the leak makes it difficult to accurately assess the impact of the nitrogen purge on the overall product distribution. 
Table 37. Mass balance for alkaline-catalyzed liquefaction runs

\begin{tabular}{|c|c|c|c|c|}
\hline \multicolumn{5}{|c|}{ Mass Balances on Liquefaction Runs 1-8 } \\
\hline Run & $\begin{array}{c}\text { Starting } \\
\text { Material } \\
\text { Mass (g) }\end{array}$ & $\begin{array}{c}\text { Liquid } \\
\text { Product } \\
\text { Mass (g) }\end{array}$ & $\begin{array}{c}\text { Solid } \\
\text { Product } \\
\text { Mass (g) }\end{array}$ & $\begin{array}{c}\text { Gas } \\
\text { Product } \\
\text { Mass (g) }\end{array}$ \\
\hline 1 & 90.0 & NA & 10.4 & NA \\
2 & 90.0 & 48.0 & 28.7 & 13.3 \\
3 & 86.0 & 42.0 & 30.8 & 13.2 \\
4 & 86.0 & 46.9 & 25.6 & 13.5 \\
5 & 86.0 & 55.7 & 23.0 & 7.3 \\
6 & 86.0 & 53.4 & 26.3 & 6.3 \\
7 & 90.0 & 53.0 & 27.7 & 9.3 \\
8 & 90.0 & 49.8 & 28.0 & 12.2 \\
\hline
\end{tabular}

Figure 7 depicts the normalized compositional gas analyses from the alkaline-catalyzed liquefaction runs. Oxygen was detected in the gas product on the order of $2-4 \% \mathrm{w} / \mathrm{w}$. Does this indicate incomplete pyrolysis?? It is unlikely that oxygen could be present in the final product gas in such a quantity, especially in the runs that were purged for twenty minutes with nitrogen. Upon running the $\mathrm{GC}$ with a $25 \mu \mathrm{L}$ helium blank injection, it was verified that air was indeed entering the chromatographic system upon injection in a fairly reproducible fashion. Since it is improbable that free nitrogen or oxygen would be formed under the conditions for pyrolysis, they have been effectively omitted from the final analysis of the permanent gas products by deducting the total amount of nitrogen in the system and the stoichiometric equivalent of oxygen. A negligible amount of oxygen remained from CLM runs 2 and 3 and bagasse run 2. Carbon dioxide was present in the highest abundance, constituting a normalized average of approximately $90.2 \% \mathrm{w} / \mathrm{w}$ of the permanent gas mass, while carbon monoxide was the second most prolific permanent gas contributing a normalized average of $9.7 \% \mathrm{w} / \mathrm{w}$ of the gas mass. 
Figure 7. Normalized compositional analysis of base catalyzed liquefaction runs

Normalized Compositional Analy sis of Alkaline Catalyzed Sugarcane Liquefaction Runs



GC-MS was utilized to provide a qualitative assessment of the major constituents present in the liquid product from the alkaline-catalyzed liquefaction runs. The two major classes of compounds contained within the liquid product as revealed by the GC-MS characterization work (Table 38) are phenols and ketones. Typically, match qualities at 60 or above are considered to be reliable library matches for the unknown peak. A few match qualities are posted that are below this threshold. These were included to illustrate a possibly important distinction between compounds present in the bagasse-derived liquids and the CLM-derived liquids. Compounds containing the chemical formula $\mathrm{C}_{8} \mathrm{H}_{14}$ arise in the $\mathrm{GC}-\mathrm{MS}$ results for both CLM runs. In other circumstances, the lower quality matches were included to demonstrate that both the CLM and bagasse liquid products contain similar types of compounds, such as the dimethylated ketones (2,3-dimethyl-2-cyclopenten-1-one). The loss in match quality in compounds such as the former ketone is unavoidable since the determination of the actual configuration of identical functional groups on cyclic or ring compounds is often ambiguous when using a mass spectrometer, which classifies compounds according to the mass to charge ratios of their respective fragment patterns. 
Table 38. Qualitative characterization of liquid products from subcritical aqueous alkalicatalyzed sugarcane conversion

\begin{tabular}{|c|c|c|c|}
\hline \multicolumn{4}{|c|}{ Bagasse Pyrolysis Run 1 - DCM Extraction GC-MS Results } \\
\hline Residence Time & Compound & Formula & \% Quality \\
\hline 6.552 & 3 - Methyl - 2 - cyclopenten - 1 - one & $\mathrm{C} 6 \mathrm{H} 8 \mathrm{O}$ & 59 \\
\hline 7.441 & Phenol & $\mathrm{C} 6 \mathrm{H} 6 \mathrm{O}$ & \\
\hline 7.993 & 2 - Hydroxy - 3 - methyl - 2 - cyclopenten - 1- one & $\mathrm{C} 6 \mathrm{H} 8 \mathrm{O} 2$ & 5 \\
\hline \multirow[t]{2}{*}{8.632} & 2 - Methoxy - phenol & $\mathrm{C} 7 \mathrm{H} 8 \mathrm{O} 2$ & \\
\hline & Mequinol (4 - Methoxy - phenol) & $\mathrm{C} 7 \mathrm{H} 8 \mathrm{O} 2$ & \\
\hline \multirow[t]{2}{*}{9.358} & 4 - Ethyl - phenol & $\mathrm{C} 8 \mathrm{H} 10 \mathrm{O}$ & \\
\hline & 2 - Ethyl - phenol & $\mathrm{C} 8 \mathrm{H} 10 \mathrm{O}$ & \\
\hline 10.311 & 4 - Ethyl - 2 - methoxy - phenol & $\mathrm{C} 9 \mathrm{H} 12 \mathrm{O} 2$ & \\
\hline 10.312 & 2 - Methoxy - 4 - methylbicyclo[3.2.1] oct - 2 - ene & $\mathrm{C} 10 \mathrm{H} 6 \mathrm{O}$ & \\
\hline 10.322 & 5 - Isopropyl - 3,3 - dimethyl - 2 - methylene - 2,3 - dihydrofuran & $\mathrm{C} 10 \mathrm{H} 16 \mathrm{O}$ & \\
\hline 10.864 & 2,6 - Dimethoxy - phenol & $\mathrm{C} 8 \mathrm{H} 10 \mathrm{O} 3$ & \\
\hline
\end{tabular}

\begin{tabular}{lllr}
$\begin{array}{l}\text { Bagasse Pyrolysis Run 2 - DCM Extraction GC-MS Results } \\
\text { Residence Time }\end{array}$ & Compound & Formula & \% Quality \\
\hline 6.533 & 2 - Methyl - cyclopenten - 1 - one & C6H8O & 72 \\
7.443 & Phenol & C6H6O & 83 \\
8.114 & 2,3 - Dimethyl - 2 - cyclopenten - 1 - one & C7H10O & 52 \\
8.634 & 2 - Methoxy - phenol & C7H8O2 & 94 \\
9.338 & 4 - Ethyl - phenol & C8H10O & 81 \\
10.302 & 7,7 - Dimethylbicyclo[3.3.0]octan - 2 - one & C10H16O & 83 \\
10.866 & 2,6 - Dimethoxy - phenol & C8H10O3 & 95 \\
\hline
\end{tabular}

CLM Pyrolysis Run 1 - DCM Extraction GC-MS Results

\begin{tabular}{lllr} 
Residence Time & Compound & Formula & \% Quality \\
\hline 4.856 & 3,4 - Dihydro - 2H - Pyran & C5H8O & 64 \\
6.546 & 2 - Methyl - 2 - cyclopenten - 1 - one & C6H8O & 86 \\
7.326 & 3 - Methyl - 2 - cyclopenten - 1 - one & C6H8O & 64 \\
& 2 - Methyl - 3 - hexyne & C7H12 & 64 \\
7.456 & Phenol & C6H6O & 87 \\
7.651 & 1,2 - Dimethyl - cyclohexene & C8H14 & 58 \\
7.673 & 6 - Methyl - 3 - heptyne & C7H10O & 50 \\
8.106 & 2,3 - Dimethyl - 2 - cyclopenten - 1 - one & C7H8O2 & 59 \\
8.626 & 2 - Methoxy - phenol & C8H10O & 68 \\
9.341 & 3 - Ethyl - phenol & C8H10O & 83 \\
9.352 & 4 - Ethyl - phenol & C9H12O2 & 90 \\
10.316 & 4 - Ethyl - 2 - methoxy - phenol & C8H10O3 & 81 \\
10.880 & 2,6 - Dimethoxy - phenol & &
\end{tabular}

CLM Pyrolysis Run 2 - DCM Extraction GC-MS Results

Residence Time Compound

$4.790 \quad 3,4$ - Dihydro - $2 \mathrm{H}$ - pyran

5.4732 - Cyclopenten - 1 - one

6.4912 - Methyl - 2 - cyclopenten - 1 - one

7.249 3- Methyl - 2 - cyclopenten - 1 - one

$7.390 \quad$ Phenol

$7.585 \quad 3,4$ - Dimethyl - 2 - cyclopenten - 1 - one

$7.628 \quad 2,3$ - Dimethyl - 2 - cyclopenten - 1 - one

$7.910 \quad$ Cyclohexane

$8.051 \quad 2,3$ - Dimethyl - 2 - cyclopenten - 1 - one

8.5712 - Methoxy - phenol

$9.286 \quad 3$ - Ethyl - phenol

$9.297 \quad 4$ - Ethyl - phenol

9.535 2- Methoxy - 4 - methyl - phenol

10.25044 - Ethyl - 2 - methoxy - phenol

$10.813 \quad 2,6-$ Dimethoxy - phenol

$\begin{array}{lr}\text { Formula } & \text { \% Quality } \\ \mathrm{C} 5 \mathrm{H} 8 \mathrm{O} & 72 \\ \mathrm{C} 5 \mathrm{H} 6 \mathrm{O} & 64 \\ \mathrm{C} 6 \mathrm{H} 8 \mathrm{O} & 90 \\ \mathrm{C} 6 \mathrm{H} 8 \mathrm{O} & 91 \\ \mathrm{C} 6 \mathrm{H} 6 \mathrm{O} & 90 \\ \mathrm{C} 7 \mathrm{H} 10 \mathrm{O} & 90 \\ \mathrm{C} 7 \mathrm{H} 10 \mathrm{O} & 86 \\ \mathrm{C} 8 \mathrm{H} 14 & 64 \\ \mathrm{C} 7 \mathrm{H} 10 \mathrm{O} & 83 \\ \mathrm{C} 7 \mathrm{H} 8 \mathrm{O} 2 & 96 \\ \mathrm{C} 8 \mathrm{H} 10 \mathrm{O} & 81 \\ \mathrm{C} 8 \mathrm{H} 10 \mathrm{O} & 87 \\ \mathrm{C} 8 \mathrm{H} 10 \mathrm{O} 2 & 96 \\ \mathrm{C} 9 \mathrm{H} 12 \mathrm{O} 2 & 95 \\ \mathrm{C} 8 \mathrm{H} 10 \mathrm{O} 3 & 93\end{array}$


Due to the potential contribution of the sodium carbonate catalyst to the product yield and composition of the sugarcane residue liquefaction runs, it was deemed necessary to run a set of control tests having no catalyst. All of these tests were run with CLM at an identical 20:1 mass ratio of water to moist biomass. The CLM had an average as-received moisture level of $14 \%$. The CLM and water were continuously mixed with a helical impeller and heated to $300^{\circ} \mathrm{C}$ at a rate of $4{ }^{\circ} \mathrm{C} / \mathrm{min}$. The CLM slurry was soaked at $300^{\circ} \mathrm{C}$ for one hour. The control (\#1) was run under an air environment, while controls (\#2 through 7) were either purged or sparged with an inert gas. Control \#2 was purged with nitrogen for 5 min using an in-line pressure of 30 psia. Control \# 3 was purged with nitrogen for 50 minutes using an in-line pressure of $40 \mathrm{psia}$. Argon was used to purge the reactor system in control run 4 for $13 \mathrm{~min}$ at a flowrate of $2 \mathrm{l} / \mathrm{min}$. In control \# 5, argon was used to sparge the system at $105^{\circ} \mathrm{C}$ for $5 \mathrm{~min}$. Control run 6 was sparged with argon at $105^{\circ} \mathrm{C}$ for $7 \mathrm{~min}$. Control \# 7 was sparged with argon at $105^{\circ} \mathrm{C}$ for $5 \mathrm{~min}$. Table 39 indicates the mass balance for the liquefaction control runs.

Table 39. Mass balance for non-catalyzed liquefaction control runs

\begin{tabular}{|c|c|c|c|c|}
\hline \multicolumn{5}{|c|}{ Mass Balance on CLM Liquefaction Control Runs 1-7 } \\
\hline Run & $\begin{array}{c}\text { Starting Material } \\
\text { Mass (g) }\end{array}$ & $\begin{array}{c}\text { Liquid Product } \\
\text { Mass (g) }\end{array}$ & $\begin{array}{c}\text { Solid Product } \\
\text { Mass (g) }\end{array}$ & $\begin{array}{c}\text { Gas Product } \\
\text { Mass (g) }\end{array}$ \\
\hline 1 & 86.0 & 52.7 & 22.4 & 10.9 \\
2 & 86.0 & 40.0 & 36.6 & 9.4 \\
3 & 86.0 & 45.7 & 29.3 & 11.0 \\
4 & 86.0 & 34.9 & 34.3 & 16.8 \\
5 & 86.0 & 45.2 & 35.4 & 5.4 \\
6 & 86.0 & 54.7 & 28.6 & 2.7 \\
7 & 86.0 & 40.4 & 41.4 & 4.2 \\
\hline
\end{tabular}


Figure 8 depicts the normalized compositional gas analyses for the liquefaction control runs.

Figure 8. Normalized gas composition for liquefaction control runs with CLM

Normalized Permanent Gas Compositions from CLM Control Runs

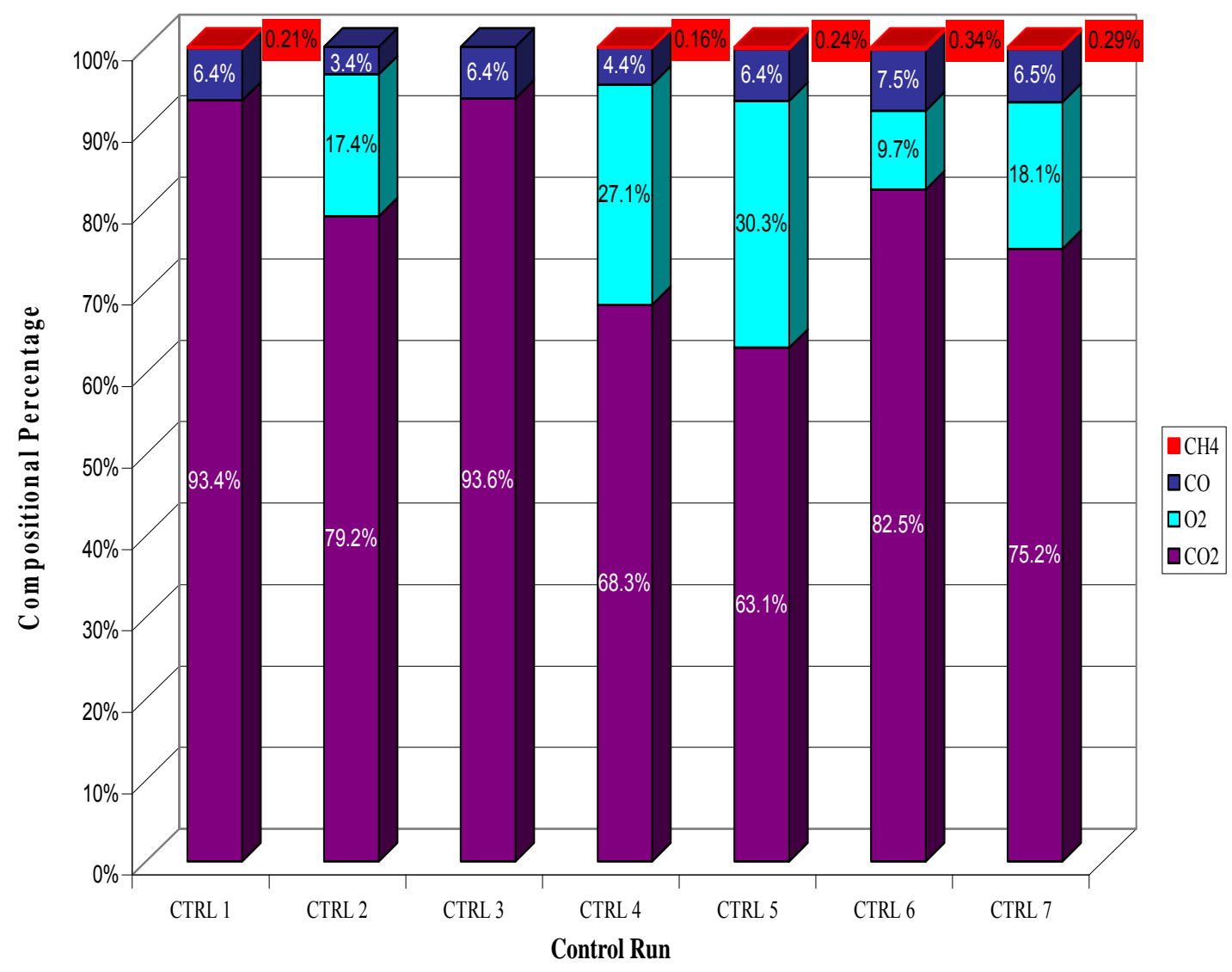

GC-MS analysis was also conducted on the liquid products from the CLM liquefaction control runs. The same five phenolic compounds predominate in the mass spectral analyses of three different control runs and the column retention times are almost identical as shown in Table 40. The identical phenolic compounds are also found in the previous alkaline-catalyzed liquefaction runs. total recoverable phenolics was determined for a randomly selected control run to obtain estimate of the concentration of phenolics present in the aqueous organic product. A phenolic concentration of $1 \mathrm{mg} / \mathrm{l}$ was obtained using the EPA total recoverable phenolics spectrophotometric determination method. A spectrophotometric method (Folin-Ciocalteau), yielded roughly 20 times the concentration of phenolics, or $20 \mathrm{mg} / \mathrm{l}$. A comparison of these two methods using a known concentration of a standard phenolic, such as vanillin, is required to more accurately quantify the amount of deviation between these two procedures. 
Table 3. GC-MS analysis of the most dominant compounds in the CLM control run liquids

\begin{tabular}{|c|l|c|c|c|}
\hline Run & \multicolumn{1}{|c|}{ Compound } & Area \% & $\begin{array}{c}\text { Retention } \\
\text { Time }\end{array}$ & $\begin{array}{c}\text { Match } \\
\text { Quality }\end{array}$ \\
\hline Control 3 & 2-Methoxy-phenol & 13.46 & 7.49 & 94 \\
& Phenol & 12.51 & 5.15 & 91 \\
& 4-Ethyl-phenol & 8.22 & 8.87 & 94 \\
& 2,6-Dimethoxy-phenol & 7.85 & 11.82 & 93 \\
& 4-Ethyl-2-methoxy-phenol & 5.15 & 10.76 & 91 \\
& 2,3-Dimethylcyclopent-2-en-1- & 3.34 & 6.54 & 93 \\
& one & & & \\
& 1,4-Dimethoxy-phenol & 2.86 & 9.38 & 91 \\
\hline Control 5 & 2-Methoxy-phenol & 14.53 & 7.50 & 94 \\
& Phenol & 11.78 & 5.17 & 91 \\
& 2,6-Dimethoxy-phenol & 11.31 & 11.82 & 90 \\
& 4-Ethyl-phenol & 11.09 & 8.88 & 94 \\
& 4-Ethyl-2-methoxy-phenol & 5.83 & 10.76 & 87 \\
& 2,3-Dimethylcyclopent-2-en-1- & 2.86 & 6.53 & 94 \\
& one & & & \\
& 2-Methoxy-4-methyl-phenol & 2.65 & 9.38 & 95 \\
& 4-Methyl-phenol & 2.43 & 7.17 & 97 \\
\hline Control 7 & 2-Methoxy-phenol & 14.39 & 7.49 & 95 \\
& Phenol & 12.06 & 5.14 & 91 \\
& 4-Ethyl-phenol & 10.59 & 8.87 & 94 \\
& 2,6-Dimethoxy-phenol & 6.79 & 11.82 & 90 \\
& 4-Ethyl-phenol & 5.26 & 10.76 & 94 \\
& Spiropentane & 3.89 & 4.97 & 53 \\
& 4-Methyl-phenol & 3.85 & 7.15 & 87 \\
& 2,3-Dimethylcyclopent-2-en-1- & 3.19 & 6.54 & 90 \\
& one & & & \\
\hline
\end{tabular}

\section{Conclusion}

1. The composition of pyrolysis liquids is highly aromatic consequently it may be susceptible to naphtha reforming, leading to gasoline fractions as fuel.

2. Gas phases are predominantly carbon dioxide thus, a rich Syngas for chemical synthesis would be the next step for gasification.

Bagasse is approximately $50 \%$ water. Both pyrolysis and gasification must make used of watermediated reactions to achieve a competitive advantage over drier substrates. Simple hot water and near supercritical water may offer sufficient chemical reaction power to produce both syngas and pyrolysis liquids with specific characteristics without the co-formation of toxic chemicals. 
Subtask 5.2 Determine experimentally the yields of syngas per unit mass of bagasse.

Results from five samples collected at temperatures ranging from $673{ }^{\circ} \mathrm{C}$ to $765{ }^{\circ} \mathrm{C}$ were analyzed by gas chromatography are given in Table 41. A ShinCarbon ST micropacked GC column was employed. A thermal conductivity detector (TCD) was used to detect differences in thermal conductivity between the column effluent flow (carrier gas plus sample components) and the reference flow of the carrier gas. A voltage proportional to this difference is generated which becomes the output signal. The analytical method employed the following method for each gas analysis, in triplicate. The initial oven temperature was set at $40{ }^{\circ} \mathrm{C}$ and held there for $3 \mathrm{~min}$. The column was then heated to $120^{\circ} \mathrm{C}$ at a rate of $12{ }^{\circ} \mathrm{C} / \mathrm{min}$. Subsequently, the temperature was raised to $150{ }^{\circ} \mathrm{C}$ at a rate of $15{ }^{\circ} \mathrm{C} / \mathrm{min}$. This ramp was followed by a final elevation to 200 ${ }^{\circ} \mathrm{C}$ at a rate of $40{ }^{\circ} \mathrm{C} / \mathrm{min}$. The inlet temperature for the $\mathrm{GC}$ was $200{ }^{\circ} \mathrm{C}$ and the detector temperature was $280^{\circ} \mathrm{C}$. The column pressure was regulated at $60 \mathrm{psi}$ and the carrier gas was helium. The duration of each test was approximately $15 \mathrm{~min}$, including equilibration time at the initial temperature. A $2 \mathrm{~m}$ by $1 \mathrm{~mm}$ ID micropacked column was able to resolve six permanent gases: hydrogen, oxygen, nitrogen, carbon monoxide, methane, and carbon dioxide. Injections with a gas-tight syringe were made at three different volumes, including $100 \mu \mathrm{L}, 250 \mu \mathrm{L}$, and $500 \mu \mathrm{L}$. Results indicate appreciable levels of hydrogen.

Table 4: Hydrogen composition in flue gas at various combustion temperature conditions.

\begin{tabular}{|c|c|c|c|c|c|}
\hline Injection Volume & $705{ }^{\circ} \mathrm{C}$ & $728^{\circ} \mathrm{C}$ & $721{ }^{\circ} \mathrm{C}$ & $673^{\circ} \mathrm{C}$ & $765{ }^{\circ} \mathrm{C}$ \\
\hline \hline $100 \mu \mathrm{L}$ & $0.29 \mathrm{wt} \%$ & $0.34 \mathrm{wt} \%$ & $0.11 \mathrm{wt} \%$ & $0.34 \mathrm{wt} \%$ & $0.10 \mathrm{wt} \%$ \\
\hline $500 \mu \mathrm{L}$ & $0.58 \mathrm{wt} \%$ & $0.91 \mathrm{wt} \%$ & $0.33 \mathrm{wt} \%$ & $0.81 \mathrm{wt} \%$ & $0.76 \mathrm{wt} \%$ \\
\hline
\end{tabular}

Saturation of the detector likely occurred with the $500 \mu \mathrm{L}$ injection, which helps explain why the amounts detected were not five times higher than those obtained for the $100 \mu \mathrm{L}$ injection. Signs of the overloading included peaks with significant tailing for the major species such as nitrogen and carbon dioxide. Alternatively, argon and nitrogen can be used instead of helium to eliminate problems with hydrogen detection when using helium, although detector sensitivity is considerably diminished for the detection of gases other than hydrogen.

A goal of subtask 5.2 was to develop a theoretical model that effectively simulates the combustion processes occurring within the gasification unit. COMSOL Multiphysics software, which employs finite element analysis, has been used in the construction of the gasification model. Results provided a schematic representation of the sugarcane bagasse downdraft gasifier. Considerable attention was devoted to refining the mesh of the gasifier, which partitions the geometry model into a network of small units of simple shapes. The large geometric scale variations presented a significant challenge to mesh because of the inclusion of some very thin layers. The thin domains were meshed with a swept mesher, which is less sensitive to thin regions than the free mesher. The interactive meshing tool was used to separately mesh the rest of the domains using a free mesher. 
Initially, the fluid transport through the downdraft gasifier was simply modeled using a laminar flow with the Navier-Stokes equations. In the fully developed laminar flow model there were only velocity components in the main direction of the flow. In reality, however, the gasifier is likely to have a mixture of turbulent flow and laminar flow. Unlike the flow in the laminar regime, flows in the turbulent flow regimes exhibit a velocity profile will vary perpendicularly to flow as the flow proceeds downstream.

Inclusion of a turbulent flow regime domain requires a simplification of the momentum transport equation to avoid the large number of finite elements that would be necessary to account for all of the dynamics of the fluid flow. Moreover, turbulence also presents a difficulty when trying to resolve fluid flow near walls. These zones contain small chaotic eddies as well as boundary layer formation, both of which must be resolved from the main body fluid flow. The first requirement for turbulent flow analysis involves the evaluation of the mean flow characteristics through the use of a Reynolds averaged representation of the turbulent flows that is inserted into the Navier-Stokes equation assuming a constant viscosity. Closure of the turbulence model is then achieved by incorporating the $k-\varepsilon$ assumption which broadly implies that momentum transport attributable to small eddies is translated to transport by shear, or turbulent viscosity. The turbulent viscosity term has been replaced by field variables for which the transport equations are defined, namely the turbulence kinetic energy, $k$, and the dissipation rate of turbulence energy, $\varepsilon$.

Convergence of the solution for the turbulent flow model is of utmost importance and the model is currently being tested in a stepwise fashion for increasing velocities. Currently, the model solution has converged for a velocity of $0.0005 \mathrm{~m} / \mathrm{s}$. Velocity values above this level have resulted in non-convergence because the $k-\varepsilon$ closure application mode utilizes an empirical relation between the value of the flow velocity and the wall friction substitutes the thin boundary layer near the wall. Although this method is relatively accurate for high Reynolds numbers, it begins to break down for moderate to low Reynolds number turbulent models as in the sugarcane bagasse gasifier model. In this case, we have had to refine the mesh near the wall so that the "viscous" sublayer can be resolved. Due to modeling restrictions with the current version of COMSOL, it may be necessary to develop both a purely laminar model and a wholly turbulent flow model. Experimentation on agasifier at transitional flows will then be required to obtain data points that can be used to plot a curve between the laminar and turbulent regimes.

Figure 9 depicts the turbulent flow model for the gasifier at $0.0005 \mathrm{~m} / \mathrm{s}$. Air passing through the uppermost region of the gasifier almost immediately encounters a region of turbulence, which is caused by the presence of a thin circular arc about the inner perimeter of the gasifier. After this zone, the gas flow proceeds down through the gasifier until it reaches the packed bed containing the sugarcane bagasse and cane trash. Flow through the packed bed becomes strangled and is then forced through another porous bed containing charcoal and bagasse in the cylindrical combustion core. Gas flow through the combustion chamber approaches the highest velocity in the entire gasifier. The tightly banded streamlines are indicative of higher velocity rates. The gas that leaves the combustion cylinder is subjected to a turbulent flow field, which can be seen from the sizeable eddies that form both at the exit of this cylinder and also at entrance to the 
exhaust tube of the gasification reactor. In both cases, the turbulence arises from gas flow that experiences a significant expansion or constriction to movement, respectively.

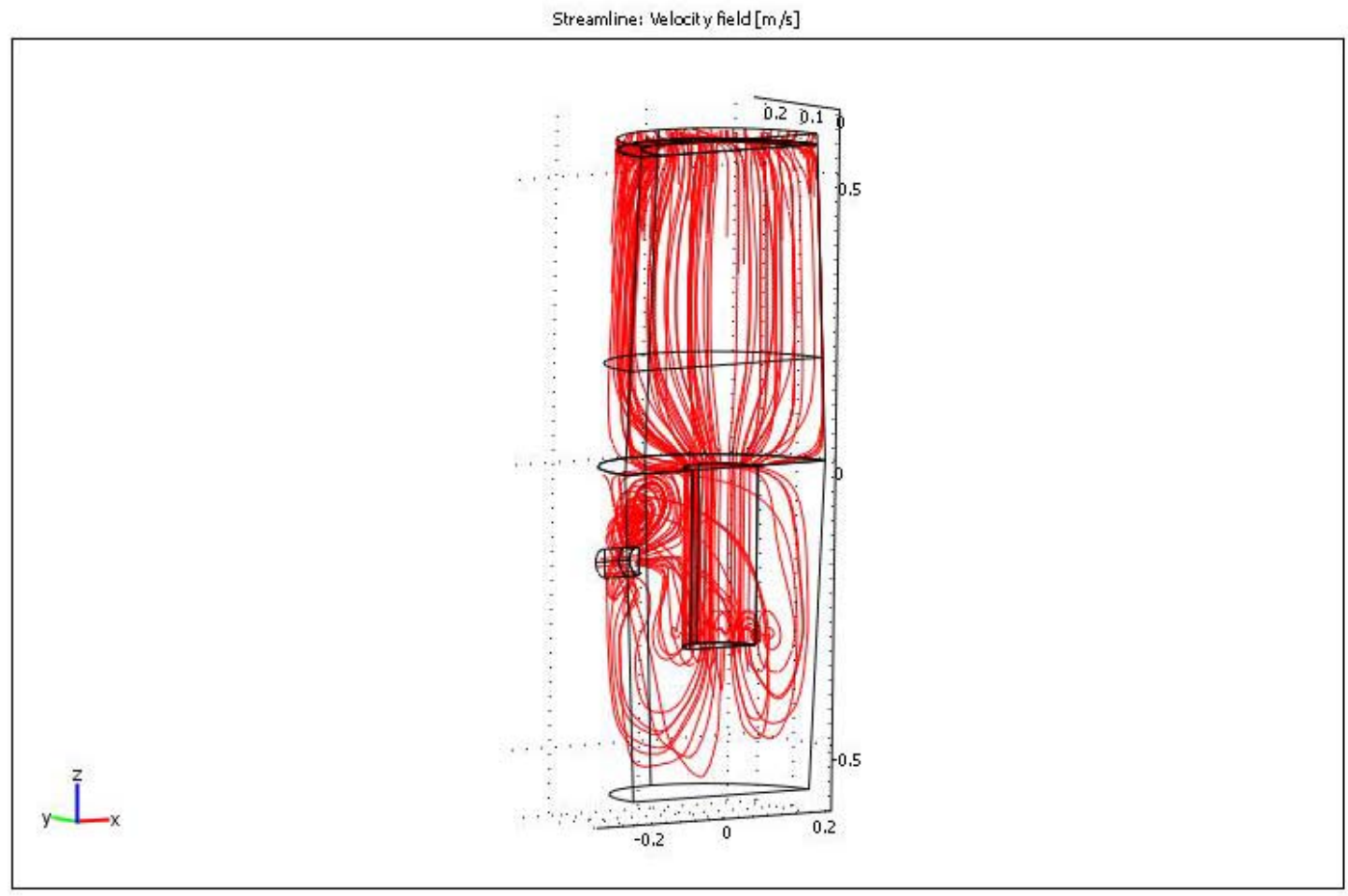

Figure 9. Velocity profile for the downdraft sugarcane bagasse gasifier

During the second quarter advances were also made on the temperature profile modeling of the gasifier. COMSOL Multiphysics was again used to facilitate the theoretical modeling of the heat transfer within the gasification process. A general heat transfer application mode was applied that includes both conduction and convective heat transport terms. Conduction through the galvanized steel walls of the gasifier is included in this model by accounting for the thermal conductivity of the steel. Convection, however, plays a much larger role in the heat transport than do heat losses via conduction in the gasifier. Presently, the source of heat, $q$, is designated to be approximately $25 \mathrm{~W} / \mathrm{m}^{3}$. The heat emanates from the combustion core, where the gasification reactions occur.

Figure 10 indicates the steady state temperature profile of the gasification reactor after approximately one hour of operation. The temperature at the core center has reached $1042{ }^{\circ} \mathrm{C}$. The illustration also depicts the loss of heat through the galvanized steel walls to the outside, which is held constant at an ambient temperature of $25^{\circ} \mathrm{C}$. The arrows represent the temperature gradients within the gasifier. 




Figure 10. Temperature profile of a gasification reactor (after $1 \mathrm{hr}$ operation)

A laboratory scale gasifier prototype was designed (see Figure 11 below) but not constructed because of safety concerns at the proposed site. A model for the heat transfer through the reaction cells was created. The model predicted that the shortest time to temperature would be approximately 30 minutes. This did not correlate well with experimental results using a reaction cell filled with sand, which indicated heat transfer rates that were on the order of 6 times faster. 


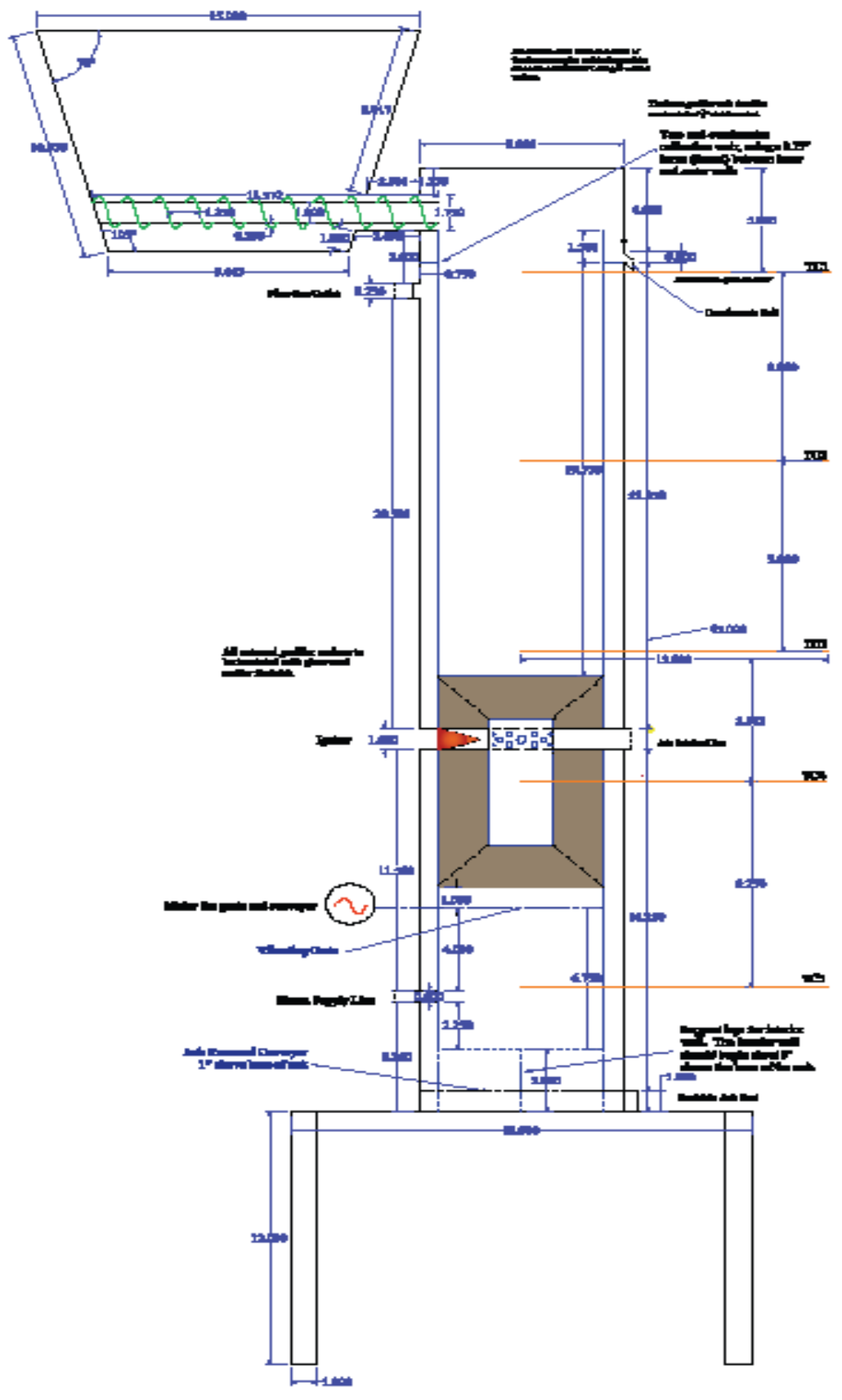

Figure 11.Proposed laboratory prototype gasification reactor for bagasse. 
Temperature control studies in a molten metal furnace were conducted. An accurate portrayal of the hysteresis resulting from the single-loop feedback controller was rendered. The initial overshoot in temperature was typically between 6-9\% of the set-point temperature. Successive temperature overshoots are no more than $3 \%$ higher than the set-point temperature. The resulting dip in temperature between overshoots is always less than $1 \%$ absolute deviation from set-point temperature. The time to reach the desired set-point temperature from ambient outside air temperature is on the order of 5 to 6 minutes using a reaction cell filled with sand. The use of water within the cell might translate to a maximum time savings of 45 seconds to 1 minute. The bulk of the heating time occurs while the heat is being conducted through the Hastelloy walls of the reaction cell. These walls tend to behave as highly unfavorable thermal conductors. It was discovered that the greatest hindrance to the heating occurs during the ramp from ambient temperature to $100{ }^{\circ} \mathrm{C}$. It is believed that this is the combined effect of thermal inertia and the time required to drive off any residual moisture within the cell.

\section{Conclusions}

Gasification research was terminated at the end of the project. Although the gasification approach is promising for producing ethanol from biomass it was felt that the expense of a gasifier of sufficient scale to prove the result was beyond the capability of a University based research group. Gasification also minimized the chances of finding a range of by-products from the process that would improve the economic viability of a sugar mill based borefinery.

\section{Materials and Methods (task 5)}

The compositional gas analysis was conducted on an HP 5890 GC unit using a Shincarbon ST $^{\circledR}$ micropacked column (Restek Corporation; Bellefonte, PA) fitted with a thermal conductivity detector (TCD). Helium was selected as the carrier gas and set at a pressure of 22 psi and a flowrate of approximately $10 \mathrm{ml} / \mathrm{min}$. An internal standard (SCOTTY Gases; Pittsburgh, PA) was used to calibrate the measurements and had the following permanent gases with the corresponding molar compositions: $5.00 \% \mathrm{CO}_{2}, 5.03 \% \mathrm{CO}_{2}, 4.00 \% \mathrm{H}_{2}, 3.96 \% \mathrm{CH}_{4}, 5.05 \%$ $\mathrm{N}_{2}$, with the balance consisting of helium. The gas standard injection volume ranged between 50 and $100 \mu \mathrm{l}$, while the sample gas injection volume varied between 50 and $200 \mu \mathrm{l}$. The temperature program profile used to perform the gas chromatography is provided here: Begin at 28 or $30{ }^{\circ} \mathrm{C}$, hold for $3 \mathrm{~min}$ and then ramp to $120^{\circ} \mathrm{C}$ at $45^{\circ} \mathrm{C} / \mathrm{min}$ with no hold time; then ramp to $150{ }^{\circ} \mathrm{C}$ at $40{ }^{\circ} \mathrm{C} / \mathrm{min}$ with no hold time; continue to ramp to $200{ }^{\circ} \mathrm{C} / \mathrm{min}$ with a $2.75 \mathrm{~min}$ hold before terminating the program. The total analysis run time was either $9.97 \mathrm{~min}$ or $9.93 \mathrm{~min}$ depending on the initial starting temperature, respectively. A slightly abridged version of this program was used for control runs 4 and 5. In this program the beginning temperature was $35^{\circ} \mathrm{C}$ and after being held constant for 3 min the oven temperature was increased to $200{ }^{\circ} \mathrm{C}$ at a rate of $40{ }^{\circ} \mathrm{C} / \mathrm{min}$, followed by a $2.50 \mathrm{~min}$ hold time before program termination. The total run time for this abridged profile was $9.63 \mathrm{~min}$. Both the injector and detector temperatures in this program were set to $110^{\circ} \mathrm{C}$, while the helium carrier gas was set to a pressure of 40 psi at a flowrate of 20 $\mathrm{ml} / \mathrm{min}$.

TASKS 5.1 and 5.2

Eight subcritical aqueous alkali-catalyzed sugarcane liquefaction experiments were conducted using a 20:1 mass ratio of water to moist sugarcane biomass. As-received bagasse had $10 \%$ 
moisture content and cane leaf matter (CLM) had $14 \%$ moisture content. Alkaline catalyst was added in the form of sodium carbonate in the amount of $5 \% \mathrm{w} / \mathrm{w}$ per run. The biomass slurry was continuously stirred and heated at a ramp rate of approximately $2.5-4.0{ }^{\circ} \mathrm{C} / \mathrm{min}$ to $300{ }^{\circ} \mathrm{C}$ and soaked at this temperature for approximately one hour. After an hour-long soak, the heating coil was switched off and the reactor was allowed to return to ambient room temperature $\left(20^{\circ} \mathrm{C}\right)$ over the course of about 12 hours.

Gases were collected at ambient temperature while the system was under slightly positive pressure and measured via volume displacement of water in a glass bell jar. The liquid products from these eight runs were initially filtered on No. 42 Whatman filter paper to remove the entrained particulate matter. The coloration of the liquid products after filtration closely resembled that of apple juice. Upon storage at $4{ }^{\circ} \mathrm{C}$ for about 72 hours, the appearance of the liquid products darkened considerably to a dark olive-green color with a yellowish cast. Storage at durations beyond one year has not resulted in any additional color intensification. The liquid products have a distinctive smoky, hickory aroma that has not changed throughout the storage period.

The first four tests were carried out under an atmospheric environment, whereas the final four tests were run after first purging with nitrogen gas for 20 min to reduce the likelihood of oxygen presence in the system. No gas was collected from the Parr reactor from the first run. The second run used a much slower ramp rate corresponding to about $1{ }^{\circ} \mathrm{C} / \mathrm{min}$. The biomass slurry in the fourth run was left to liquefy at the soak temperature for about $90 \mathrm{~min}$. Runs $5-8$ were purged under nitrogen for approximately $20-30 \mathrm{~min}$ and on run 6 the reactor drain was accidentally left partially open for the first few minutes of the run, potentially resulting in the loss of some liquid product. Loss of some gas product is highly probable in run 5 due to a suspected minor leak in the tubing fittings.

\section{References}

Adney, B. \& Baker, J. 1996. Measurement of cellulase activities. NREL laboratory analytical procedure. LAP-006.

Alizadeh, H., Teymouri, F., Gilbert, Th., Dale, B., 2005. "Pretreatment of Switchgrass by ammonia fiber explosion (AFEX)". Applied Biochemistry and Biotechnology, Vol 121-124, pp. 1133-1142.

Bailey, M.J., Biely, P. \& Poutanen, K. 1992. Interlaboratory testing of methods for assay of xylanase activity. Journal of Biotechnology 23: 257-270.

Berlin, A., N. Gilkes, D. Kilburn, R. Bura, A. Matkov, A. Skomatovsky, O. Okunev, A. Gusakov, V. Maximenko, D. Gregg, A. Sinitsyn \& J. Saddler. 2005. Evaluation of novel fungal cellulose preparations for ability to hydrolyze softwood substrates-evidence for the role of accessory enzymes. Enzyme and Microbial Technology 37: 175-184. 
Fox, D. J., P. P. Gray, N. W. Dunn \& W. L. Marsden. 1987. Factors affecting the enzymatic susceptibility of alkali and acid pretreated sugar-cane bagasse. Journal of Chemical Technology and Biotechnology 40: 117-132.

Holtzapple, M. T., J.-H. Jun, G. Ashok, S. L. Patibandla \& B. E. Dalde. 1991. The ammonia freeze explosion process. Applied Biochemistry and Biotechnology 28/29: 59-74.

Kaar, W. E., C. V. Gutierrez and C. M. Kinoshita. 1998. Steam explosion of sugarcane bagasse as a pretreatment for conversion to ethanol. Biomass and Bioenergy 14: 277-287.

Laureano-Perez, L., Teymouri F Alizadeh H., Dale B.,2005. Understanding factors that limit enzymatic hydrolysis of biomass, Applied Biochemistry and Biotechnology, Vol 121-124, pp 1081-1099.

Mosier, N., Wyman, C., Dale, B., Elander, R., Lee, Y.Y., Holtzapple, M., Ladish, M., 2005. Features of promising technologies for pretreatment of lignocellulosic biomass. Bioresource Technology 96, pp. 673-686.

Martin, C., M. Galbe, C. F. Wahlbom, B. Hahn-Hägerdal \& L. J. Jönsson. 2002. Ethanol production from enzymatic hydrolysates of sugarcane bagasse using recombinant xyloseutilizing Saccharomyces cerevisiae. Enzyme and Microbial technology 31: 274-282.

Mosier, N., C. Wyman, B. Dale, R. Elander, Y. Y. Lee, M. Holtzapple \& M. Ladisch. 2005. Features of promising technologies for pretreatment of lignocellulose biomass. Bioresource Technology 96: 673-686.

Shishir, P.S., Chundawat, Balan Venkatesh, Bruce E. Dale, 2006. Effect of Particle Size Based Separation of Milled Corn Stover on AFEX Pretreatment and Enzymatic Digestibility. Biotechnology and Bioengineering, Vol. 96, No. 2, February 1, 2007

Singh , S., B. Pillay, V. Dilsook \& B. A. Prior. 2000a. Production and properties of hemicellulose by a Thermomyces lanuginosus strain. Journal of Applied Microbiology 88: 975982.

Singh , S., B. Pillay, \& B. A. Prior. 2000b. Thermal stability of $\beta$-xylanases produced by different Thermomyces lanuginosus strains. Enzyme and Microbial Technology 26: 502-508.

Teymouri, F., Laureano-Perez, L., Alizadeh, H., Dale, B., 2004. Ammonia fiber explosion treatment of corn stover. Applied Biochemistry and Biotechnology vol. 113-116, pp., 951-963.

Teymouri, F., Laureano-Perez, L., Alizadeh, H., Dale, B., 2005. Optimization of the ammonia fiber explosion (AFEX) treatment parameter for enzymatic hydrolysis of corn stover. Bioresource Technology 96, pp2014-2018. 
Teymouri, F., Saffron, C., Guettler, M., Kleff, S. and Stowers, M. (2006) "Ethanol and Succinic Acid Production from AFEX-treated Sugar Cane Bagasse and Cane Leaf Matter (CLM)." $3^{\text {rd }}$ Annual World Congress on Industrial Biotechnology. Toronto, ON, Canada, July 11 - 14, 2006.

Teymouri, F., Guettle, M., Kleff, S. and Saffron, C. "Ethanol and Succinic Acid Production from AFEX-treated Sugar Cane Biomass". $29^{\text {th }}$ Symposium on Biotechnology for Fuels and Chemicals, Denver, CO, April 29-May 2, 2007.

Van Zyl, C., B. A. Prior \& J. C. du Preez. 1988. Production of ethanol from sugar cane bagasse hemicellulose hydrolyzate by Pichia stipitis. Applied Biochemistry and

Biotechnology 17: 357-369.

\section{Project summary}

Project Summary

The rationale for this project was to develop and evaluate scalable, integrated technologies utilizing bagasse, molasses and CLM for the production of ethanol, chemicals, biomaterials and animal feeds that can be used in a sugar mill based biorefinery. All efforts in this project were directed towards investigating those processes that could be integrated into a raw sugar mill.

Specific Objective: Develop a scalable AFEX biomass pretreatment process for bagasse (Tasks 1 and 2).

The pretreatment of bagasse via the AFEX process, followed by saccharification and fermentation demonstrated the potential of AFEX as a pretreatment for bagasse. The AFEX process conditions, which include reaction time, reaction temperature, ammonia loading, and moisture content of the biomass, were varied to determine those conditions that provide the highest glucose and xylose yield. The maximum yield from bagasse was obtained with AFEX treatment times twice as long as required for corn stover. The most effective AFEX treatment conditions for bagasse, pith and CLM were found to be $100^{\circ} \mathrm{C}$, a biomass moisture content of $40 \%$, a reaction time of 30 minutes, and an ammonia loading of $2 \mathrm{~g}$ ammonia per gram dry biomass.

The efficiency of the AFEX process was evaluated using enzyme hydrolysis. Combinations of cellulase and xylanase produced higher glucose and xylose yields from AFEXtreated material compared to hydrolysis with only cellulase. A process was developed for the separation of hemicellulose and cellulose from AFEX-treated CLM and bagasse pith using selective hydrolysis of hemicellulose by using cellulase-free xylanases for selective hydrolysis of the hemicellulose. For AFEX-treated CLM, about $52 \%$ of the xylan was converted to xylose while about $96 \%$ of the cellulose was left in the biomass. For AFEX-treated bagasse pith, about $56 \%$ of the xylan, but only $5 \%$ of the cellulose, was hydrolyzed.

Specific Objective: Develop and demonstrate processes that utilize components from sugar cane; bagasse, CLM and molasses for ethanol production (Tasks 4, 5, 6).

This research broke down into several areas, technologies to produce ethanol from AFEX treated bagasse and technologies to produce succinic acid from the xylose stream. Enzyme hydrolysis of AFEX-treated bagasse generates streams of fermentable sugars containing both C5 (xylose and arabinose) and C6 sugars (glucose). The feasibility of integrating simultaneous saccharification and fermentation (SSF) allowing two operations in the same vessel was demonstrated. Additionally, the addition of sugarcane molasses to the hydrolysate/fermentation process yielded improvements beyond what was expected solely from the addition of sugar. 
Alkaline treated biomass, unlike acid treated material, contains a significant amount of hemicellulose that needs to be hydrolyzed to monomeric sugars. The generated C5 and C6 sugar streams are useful in the production of fuels and chemicals such as ethanol and succinic acid. Succinic acid is a four-carbon dicarboxylic acid used to manufacture polymers and resins for lacquers, dyes and perfumes, industrial solvents, and newly developed products such as de-icing chemicals. It can be produced via bacterial fermentation using renewable biomass-derived sugars. MBI identified a bacterium, Actinobacillus succinogenes, capable of utilizing both hexose and pentose sugars simultaneously for the production of succinic acid. Fermentability of the enzyme hydrolysate from AFEX-treated CLM was assessed for succinic acid production. Using SHF processes, with different solid loadings for succinic acid fermentation with Actinobacillus succinogenes FZ45, generated sugars (C5 and C6) were converted to succinic acid. MBI's existing ASPEN Plus-based process model for production of succinic acid from pure sugars was modified to evaluate the technical and economic performance of succinic acid production from AFEX-treated biomass. The model showed that the capital and manufacturing costs would be decreased if the cost associated with hydrolysis was decreased. Improving cellulase activity in the presence of increased solids loading would provide a lower AFEX cost, a higher succinic acid and ethanol titer, and lower downstream processing costs.

Specific Objective: Investigate the feasibility of gasification of bagasse for ethanol production

Gasification research was terminated at the end of the project. Although the gasification approach was promising for producing ethanol from biomass it was felt that the expense of a gasifier of sufficient scale to prove the result was beyond the capability of a University based research group. Gasification also minimized the chances of finding a range of by-products from the process that would improve the economic viability of a sugar mill based borefinery.

\section{Products and Technology Transfer Activities}

Publications, conference papers and other public releases:

Negulescu, I. I., Saska, M. etal (2004) Biobased Derived Nonwoven Materials. Proc. Int. TANDEC Annual Conf. 14, Knoxville, TN, Nov 9-11.

Rein, P. W. (2004) Feasibility Study on the Production of Fuel Alcohol from Louisiana Molasses. Sugar Bulletin 82, 12: 13-17.

Day, D. F., Chung, C. H., Lee, Y. J. (2005). Chemical Oxidation for Cellulose Separation, ACS National Meeting 229, San Diego, CA, March

13-17.

Rein, P. W. (2005). Utilization of Sugarcane Biomass for Ethanol and Chemicals Production. LA Sugar Bulletin, 83, 6: 17-19.

Rein, P. W. (2005). The Production of Ethanol in a Cane Sugar Mill. LA Sugar Bulletin, 83, 8: 13.

Rein P. W. (2005). Opportunities for the production of ethanol, electric 
power and chemicals from sugarcane in Louisiana. LA Sugar Bulletin. 84, 2: 17-19.

Tiedje, T.; Teymori, F. A.; McCalla, D.; Stowers, M.; Chung, C. H.; Day, D.

F.; Rein, P. W. (2005). Separation of cellulose from hemicellulose and lignin from sugarcane bagasse and cane leaf matter. Symp. Biotechnol. Fuels and Chem., May 1-4. Poster 3B-45.

Birkett, H. S.; Stein, J. (2006): Energy Self Sufficiency and Co-generation in Louisiana Cane Sugar Factories. J. Amer. Soc. Sugar Cane Technol., 26: 60.

Chung, C.; Day, D. F.; DeQueiroz, G. A. (2006): Enzyme Hydrolysis and Phenols Recovery Post Alkaline and Organosoly Treatment of Sugarcane Bagasse. Symp. Biotechnol. for Fuels and Chem. Proc., 28, Nashville, TN, Apr 30-May 3. Poster

Day, D. F.; Rein, P. W. (2006): Overview of the Audubon Sugar Institute Biorefinery Project. Amer. Soc. Sugar Cane Technol. LA Div., Baton Rouge, LA, 7-8 Feb. Abstract

Day, D. F.; Stradi, B.; DeQueiroz, G.; Chung, C. (2006): Bagasse to Ethanol - Pretreatment Options. Proc. Aust. Soc. Sugar Cane Technol. 28, 2-5 May, Mackay, Queensland. Abstract

DeQueiroz, G. A.; Day, D. F. (2006): Phenolic Acids Reseased Post Alkaline and/or Organosolv Treatment from Sugarcane Bagasse and Field Trash. Indust. Biotechnol. Bioprocess. Annual World Cong. 3, Toronto, Canada, 11-14 Jul. Poster

Madsen, L. R. (2006): Future Trends, Challenges, and Possibilities, Part II "An Interesting Future: Cane Processing in the U. S. and Biorefinery Concepts". Amer. Soc. Sugar Cane Technol. Joint Annual Meeting, Jun 14-16, St. Petersburg, FL. Abstract

Saska, M.; Gray, M. (2006): Lime-enhanced steam explosion pre-treatment of sugarcane leaves and bagasse for biomass ethanol production. Symp. Biotechnol. Fuels and Chem., 28, Apr 30-May 3, Nashville, TN.

Saska, M.; Gray, M. (2006): Pre-treatment of sugarcane leaves and bagasse pith with lime impregnation and steam explosion for enzymatic conversion to fermentable sugars. Symp. Biotechnol. Fuels and Chem., 28, Nashville, TN, Apr 30-May 3.

Saska, M.; Martin, C. (2006): Production of fuel ethanol from sugarcane bagasse and sugarcane trash. Cuban Cong., Sugar and Sugar Cane Derivatives, 9, Jun. Submitted

Chung, C. H.; Day, D. F. (2007): Cellulosic ethanol production from sugarcane bagasse using lime.CPERC Annual Technical Mtng, Tulane University, New Orleans, LA, 15 Aug. Presentation

Day, D. F.; Stradi, B.; DeQueiroz, G.; Chung, C. H. (2007): Bagasse to Ethanol-Pretreatment Options. ASSCT LA Division Annual Mtng., Baton Rouge, LA, 5-7 Feb 
Rein, P. W. (2007): Biofuels research at Audubon Sugar Institute. Sugar J. 69: 9, 9-10. Rein, P. W. (2007): Prospects for the conversion of a sugar mill into a biorefinery. Proc. Int. Soc. Sugar Cane Technol. 26: 44-60.

Stradi, B.; DeQueiroz, G. (2007): Integrated Biorefinery Research for the Production of Biofuels and Bioenergy. ASI Annual Factory Operations Seminar, p. 31-40, LSU Campus, Baton Rouge, LA, 22 Apr.

Prior, B. A.; Day, D. F. (2007): Hydrolysis of ammonia pretreated sugar cane bagasse with cellulase, ßglucosidase and hemicellulose preparations. Symp. Biotechnol. Fuels and Chem., 29th, Denver, Co. 29 Apr-2 May. Presentation

Chung, C. H. (2008): Cellulosic Ethanol Production. Korean J. Biotechnol. Bioeng. 23: 1, 1-7.

Chung, C. H.; Day, D. F. (2008): Cellulosic ethanol production from sugarcane bagasse using lime. Symp. Biotechnol. Fuels \& Chem., 30, New Orleans, LA, 4-7 May.

Day, D. F.; DeQueiroz, G.; Legendre, B. L. (2008): Turning sugarcane cellulose into ethanol: Energy for the future! LSU AgCenter, LA Agriculture Magazine 51: 2, Spring.

Day, D. F.; Chung, C. H. (2008): Process for Sugar Production from Lignocellulosic Biomass using Alkali Pretreatment. Patent Submitted 31 Jan.

Day, D. F. (2008): Strategies for Improving Bioenergy in the USA. Bioenergy Korea Conf. 2008 Int. Symp., Gwangju, Korea, 8-9 Apr. Presentation

Prior, B. A.; Day, D. F. (2008): Hydrolysis of ammonia pretreated sugar cane bagasse with cellulose, ß-glucosidase and hemicellulose preparation. App. Biochem. Biotechnol. 146: 151164.

DeQueiroz, G.; Bazan, V.; Ramachandran, T. P.; Legendre, B. L.; Day, D.; Stradi, B. (2008): Utilization of Fermentable Sugars from Sugarcane Bagasse to Ethanol. New Orleans Carbohydr. Symp. 15 (NOCS), SPRI, New Orleans, LA, 10-12 Apr.

\section{Inventions/Patent Applications:}

Chung, C. H.; Day, D. (2007): Process for sugar production from lignocellulosic biomass. Serial \# 60/887,684. Patent Pending 